\title{
Site U1361
}

\author{
Expedition 318 Scientists $^{2}$
}

\section{Chapter contents}

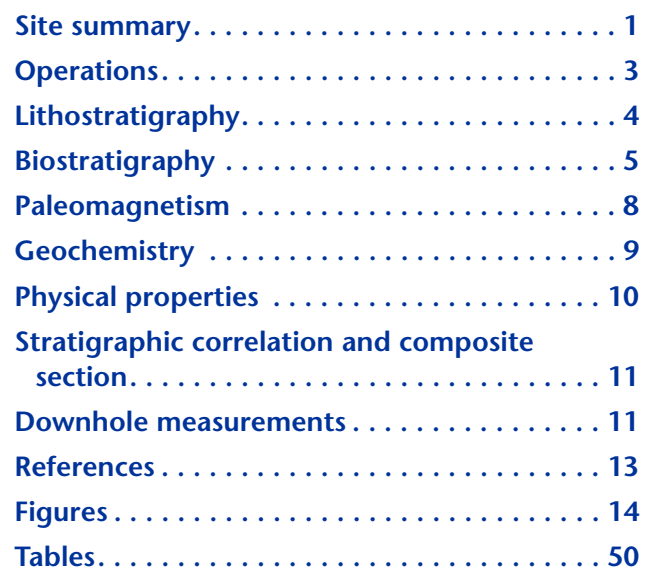

1'Expedition 318 Scientists, 2011. Site U1361. In Escutia, C., Brinkhuis, H., Klaus, A., and the Expedition 318 Scientists, Proc. IODP, 318: Tokyo (Integrated Ocean Drilling Program Management International, Inc.).

doi:10.2204/iodp.proc.318.109.2011

'Expedition 318 Scientists' addresses.

\section{Site summary}

Integrated Ocean Drilling Program Site U1361 (proposed Site WLRIS-05A) is located on the continental rise at 3454 meters below sea level (mbsl) (Fig. F1). Similar to Site U1359, the main objective at Site U1361 was to provide a history of climate and paleoceanographic variability record from the middle Miocene to the Pleistocene and to test the stability of the East Antarctic Ice Sheet (EAIS) during extreme warm periods (e.g., Miocene climate optimum, early Pliocene, and Pleistocene marine isotope Stages 31 and 11). Drilling at this site targeted the timing and nature of deposition of the upper seismic units (i.e., above unconformity WL-U6) defined on the Wilkes Land margin (De Santis et al., 2003; Donda et al., 2003) (Fig. F2). Within these units, a shift in sedimentary depocenters from the continental rise to the outer shelf possibly corresponds to the transition from a dynamic wet-based EAIS to a more persistent cold-based EAIS (Escutia et al., 2002; De Santis et al., 2003), which is inferred to occur during the late MiocenePliocene (Escutia et al., 2005; Rebesco et al., 2006). At Site U1361, unconformities WL-U6, WL-U7, and WL-U8 lie at approximately $5.13,5.03$, and $4.78 \mathrm{~s}$ two-way traveltime, respectively (approximately 385, 300, and 100 meters below seafloor [mbsf], respectively) (Fig. F2).

Site U1361 is located on the right (east) levee of the Jussieau submarine channel downstream from Site U1359 (Figs. F1, F2). The levee relief (measured from the channel thalweg to the top of the levee) at Site U1361 is 195 m (Fig. F2). The fine-grained components of the turbidity flows traveling through the channel and hemipelagic drape are inferred to be the dominant sedimentary processes building these levees (Escutia et al., 1997, 2000; Donda et al., 2003). Bottom currents can further influence sedimentation in this setting (Escutia et al., 2002; Donda et al., 2003). The record from Site U1361 should be complementary to the record from Site U1359. Similar depositional environments were cored during Ocean Drilling Program (ODP) Leg 178 along the Antarctic Peninsula (Barker, Camerlenghi, Acton, et al., 1999) and ODP Leg 188 in Prydz Bay (O'Brien, Cooper, Richter, et al., 2001).

Two holes were drilled at Site U1361. Hole U1361A reached a total depth of 388.0 mbsf. The advanced piston coring (APC) system was used to refusal at $151.5 \mathrm{mbsf}$, followed by extended core barrel (XCB) drilling to the bottom of the hole at 388.0 mbsf. Hole U1361B reached $12.1 \mathrm{mbsf}$ using the APC system. Five lithofacies 
(designated A-E) were identified at Site U1361, and based on their distribution in Hole U1361A, two lithostratigraphic units are defined (Fig. F3). Facies A and $\mathrm{B}$ consist of clays and silty clays with common diatoms and foraminifer and rare decimeter-scale sets of millimeter- to centimeter-scale silt and clay laminations. These facies are restricted to the interval between 0.0 and 34.9 mbsf (lithostratigraphic Unit I). Facies A and B were deposited in hemipelagic depositional environments, with isolated sets of silt and clay laminations indicating occasional sedimentation from low-density turbidity currents or saline density flows in a distal levee setting (Escutia et al., 2008). Facies C and D are strongly bioturbated silty clays and diatom/nannofossil oozes with intervals containing dispersed clasts. Facies E consists of laminated clays. Facies C-E are present between 34.9 and 386.3 mbsf (lithostratigraphic Unit II) and are typical of contourite facies associations, although downslope currents possibly contributed sediment as well.

Samples 318-U1361A-1H-CC through 41X-CC (1.5$386.31 \mathrm{mbsf}$ ) were analyzed for microfossils. Diatoms and radiolarians provide good age control for Hole U1361A, resolving an uppermost middle Miocene through uppermost Pleistocene sedimentary succession with no major breaks in sedimentation (Fig. F4).

Miocene diatom assemblages at Site U1361 are indicative of productive, seasonally variable open-marine conditions. Fluctuations in the abundance of marine benthic and tychopelagic taxa such as Cocconeis spp., Diploneis spp., Paralia sulcata, stephanopyxids, and Trinacria excavata may indicate pulses of shelfal material to the drill site. The presence of well-preserved benthic foraminifers in Sample 318-U1361A-34X-CC (321.07 mbsf) suggests that depositional settings were favorable for calcite preservation (i.e., not corrosive) for brief intervals in the Miocene. The persistent presence of reworked Mesozoic-Paleozoic sporomorphs within the palynological associations suggests ongoing erosion in the hinterland.

Late Neogene diatom assemblages from sediments drilled at Site U1361 are typical Southern Ocean open-water taxa with variable abundances of benthic, neritic, and sea ice-associated diatoms, indicating a high-nutrient, high-productivity sea ice-influenced setting throughout the late Neogene. High abundances of reworked sporomorphs within the palynological associations indicate strong erosion in the hinterland. Dinocysts are absent in this interval. The preservation of planktonic foraminifers in the Pleistocene indicates that bottom waters were favorable to the preservation of calcium carbonate.

Paleomagnetic investigations at Site U1361 document a complete section from the top of Chron C2n to the top of Chron C3n. Below Chron C2n, the recovered core was disturbed, and no complete analysis of the discrete samples is obtainable as of yet. The lower portion of Hole U1361A can plausibly be correlated to the bottom of Chron C5n to Chron C5An.

Forty samples from Hole U1361A were taken for analyses of carbonate, carbon, nitrogen, and sulfur content, as well as major and trace elements. As a result of technical problems with the inductively coupled plasma-atomic emission spectrometer (ICPAES), no major and trace element analyses could be obtained. $\mathrm{CaCO}_{3}$ contents for most samples are well below detection limit $(<1 \mathrm{wt} \%)$. Between 313.96 and 342.04 mbsf, however, carbonate contents increase to $12.1-24.8 \mathrm{wt} \%$. This matches the recognition of nannofossil-bearing clays constituting one of three major facies below 313.2 mbsf (lithostratigraphic Subunit IIb; see "Lithostratigraphy"). Carbon, nitrogen, and sulfur contents were measured on 15 selected samples covering the full range of $\mathrm{CaCO}_{3}$ contents ( 0 $24.8 \mathrm{wt} \%$ ). All concentration levels are very low (i.e., $\mathrm{C}<0.5 \mathrm{wt} \%, \mathrm{~N}<0.03 \mathrm{wt} \%$, and $\mathrm{S}<0.02 \mathrm{wt} \%)$ except for the four samples with high calcium carbonate contents. Taken together with the $\mathrm{CaCO}_{3}$ measurements, these samples yield total organic carbon concentrations $<0.3 \mathrm{wt} \%$, which is within the error for the respective measurements.

The physical property program at Site U1361 included routine runs on the Whole-Round Multisensor Logger (WRMSL), which includes the gamma ray attenuation (GRA) density, magnetic susceptibility, and $P$ wave logger (PWL) sensors, as well as natural gamma ray (NGR) measurements. $P$-wave velocity measurements were also taken, and samples were taken and analyzed for moisture, density, and porosity. Thermal conductivity measurements were made in one section of all cores. The magnetic susceptibility data exhibit relatively high amplitude variations, and this apparent cyclicity at several scales occurs especially in the upper $165 \mathrm{mbsf}$ and between $305 \mathrm{mbsf}$ and the bottom of the hole. There are two intervals with recurring, relatively lower magnetic susceptibility units between 165 and 185 mbsf and between 265 and 305 mbsf. The variations in GRA density reflect the regular fluctuations in lithology and porosity. The relative moisture content varies between 63 and $22 \mathrm{wt} \%$, and porosity varies from $82 \%$ to $42 \%$ with a gradual decrease with increasing depth and overburden pressure. A common feature of density, porosity, and water content records of Site U1361 is a slight change to higher gradients below 330 mbsf that occurs within lithostratigraphic Subunit IIb.

Downhole logging operations started after a successful reentry of Hole U1361A, which had been left 
temporarily to allow an iceberg to pass. Both the triple combination (triple combo) and Formation MicroScanner (FMS)-sonic tool strings logged from $\sim 100$ mbsf to the base of Hole U1361A. The downhole logs in Hole U1361A have high-amplitude 1$5 \mathrm{~m}$ scale variability superimposed on a downhole compaction trend. The character of the logs changes gradually downhole, with no major steps in the base levels, so the entire logged interval was assigned to one logging unit. It is likely that Milankovitch band variability at eccentricity and possibly obliquity periods is recorded at Site U1361. The downhole measurements at Site U1361 included four advanced piston corer temperature tool (APCT-3) deployments in Hole U1361A. Thermal resistance was calculated over the intervals overlying the APCT-3 measurements, and the resulting linear fit of the temperature gives a heat flow value of $58.2 \mathrm{~mW} / \mathrm{m}^{2}$.

\section{Operations}

\section{Transit to Site U1361}

After completing operations at Hole U1359D and attempting to reach the shelf sites (proposed Site WLSHE-12A, Site U1358, or Site U1360), we decided to conduct our final operations at Site U1361. We positioned over Site U1361 at 1945 h on 25 February 2010. The total transit distance from Hole U1359D to near-shelf proposed Site WLSHE-12A and finally to Site U1361 covered $149 \mathrm{nmi}$ at an average speed of $7.1 \mathrm{kt}$. All times in this section are given in local ship time, which was Universal Time Coordinated + $11 \mathrm{~h}$.

\section{Site U1361}

\section{Hole U1361A}

We lowered the drill string and started coring Hole U1361A at $0710 \mathrm{~h}$ on 26 February 2010. Based on the recovery of the first core, the seafloor depth was 3465.5 meters below rig floor (mbrf) (3454.3 mbsl), or $5.3 \mathrm{~m}$ shallower than the corrected precision depth recorder depth. APC coring advanced to $151.5 \mathrm{mbsf}$ and recovered $150.9 \mathrm{~m}$ (100\%) (Table T1). The first core was obtained with a standard steel core barrel, but all subsequent APC cores were taken with nonmagnetic core barrels. Temperature measurements were made while taking Cores 318-U1361A-4H, $7 \mathrm{H}$, $10 \mathrm{H}$, and $13 \mathrm{H}$ at $37.5,66.0,94.5$, and $123.0 \mathrm{mbsf}$, respectively.

We switched to XCB coring and deepened the hole from 151.5 to 388.0 mbsf. Cores 318-U1361A-17X through 41X recovered $188.0 \mathrm{~m}$ (79\%) (Table T1). After Core $41 \mathrm{X}$ was recovered at $0120 \mathrm{~h}$ on 28 February, we had to suspend coring to deploy a free-fall funnel
(FFF) because an iceberg was moving directly toward the site.

We raised the bit to 90 mbsf and deployed a FFF at $0700 \mathrm{~h}$ on 28 February. At that time, the iceberg was $5.5 \mathrm{nmi}$ away and continuing to move toward the ship. We waited until $\sim 0900 \mathrm{~h}$ to see if it would change course, but it was still heading toward us. At $0945 \mathrm{~h}$, we pulled the bit out of the hole and started moving the ship to the north and out of the iceberg's path.

The $\sim 500 \mathrm{ft}$ wide iceberg passed directly over the hole at $1245 \mathrm{~h}$. Once the iceberg had cleared the site and was no longer a threat, we moved back over the hole by $1500 \mathrm{~h}$ and the reentry camera/sonar system was deployed. At $1555 \mathrm{~h}$, the video failed when the system was $200 \mathrm{~m}$ below the ship. When we recovered the camera system we found that water had entered the cable head assembly on the main umbilical cable. As soon as it was repaired we lowered it to the end of the drill string.

We reentered Hole U1361A at 2137 h on 28 February after $15 \mathrm{~min}$ of searching and positioning the drill bit over the FFF. We lowered the drill string into the hole as the camera system was retrieved, and by $0130 \mathrm{~h}$ on $1 \mathrm{march}$ the bit had reached the bottom of the hole at 388.0 mbsf without having experienced any significant drag while running into the hole. Because of the little time remaining before we had to depart for Hobart, Australia, we decided not to continue coring and prepare the hole for downhole logging.

The hole was flushed with $50 \mathrm{bbl}$ of sepiolite mud and then displaced with $179 \mathrm{bbl}$ of $10.5 \mathrm{ppg}$ heavy mud. The drill string was raised to $88.6 \mathrm{mbsf}$ for logging. We conducted two successful logging runs with the triple combo and the FMS-sonic tool strings, with both reaching the bottom of the hole. Once logging was concluded, the bit was pulled free of the seafloor and the vessel offset $50 \mathrm{~m}$ north of Hole U1361A.

\section{Hole U1361B}

APC coring in Hole U1361B started at $0840 \mathrm{~h}$ on 2 March and established the water depth at 3466.9 mbrf. We only had time for two piston cores before the operational time for the expedition ran out, in part as a result of a delay caused by ice buildup on the APC piston rod. APC Cores 318$\mathrm{U} 1361 \mathrm{~B}-1 \mathrm{H}$ and $2 \mathrm{H}$ penetrated to $12.1 \mathrm{mbsf}$ and recovered $12.0 \mathrm{~m}(100 \%)$ (Table T1).

The drill string was recovered and the bottom-hole assembly disassembled into component parts by 2400 on 2 March. We started our transit to Hobart at $0030 \mathrm{~h}$ on $3 \mathrm{March}$. The last line ashore in Hobart was at $1500 \mathrm{~h}$ on 8 March. 


\section{Lithostratigraphy}

Two holes were drilled at Site U1361. Hole U1361A reached a total depth of 388.0 meters below seafloor (mbsf), using the APC system to refusal at $151.5 \mathrm{mbsf}$, followed by XCB drilling to the bottom of the hole. Hole U1361B reached $12.1 \mathrm{mbsf}$ using the APC. Five lithofacies (Facies A-E) were identified at Site U1361 and, based on their distribution in Hole U1361A, two lithostratigraphic units are defined (Fig. F3). Facies A and B consist of clays and silty clays with common diatoms and foraminifers and rare decimeter-scale sets of millimeter- to centimeter-scale silt and clay laminations. These facies are restricted to the interval between 0.0 and 34.9 mbsf (lithostratigraphic Unit I). Facies A and B were deposited in hemipelagic depositional environments, with isolated sets of silt and clay laminations indicating occasional sedimentation from low-density turbidity currents or saline density flows consistent with a distal levee setting (Escutia et al., 2008). Facies C and D are strongly bioturbated silty clays and diatom/nannofossil oozes with intervals containing dispersed clasts. Facies E consists of laminated clays. Facies $\mathrm{C}-\mathrm{E}$ are present between 34.9 and 388.0 mbsf (lithostratigraphic Unit II) and are typical of contourite facies associations (Stow and Piper, 1984), although downslope currents possibly contributed sediment as well. A decrease in diatom abundance was noted in smear slide observations below $\sim 313$ mbsf (Fig. F5; see also Site U1361 smear slides in "Core descriptions"). Pyrite is present in trace amounts throughout the hole.

\section{Facies descriptions}

Five lithofacies were identified in Holes U1361A and U1361B and are designated with capital letters (A-E) to avoid confusion with the facies reported at Site U1359 (see "Lithostratigraphy" in the "Site U1359" chapter):

- Facies A is characterized by light yellowish brown massive diatom-rich clay (Fig. F6).

- Facies B consists of light greenish gray to olivebrown silty clay with common foraminifers and fish fragments. This facies is mostly massive in structure (Fig. F7), although rare packages as thick as $\sim 35 \mathrm{~cm}$ of millimeter- to centimeter-scale silt and clay laminations occur locally (Fig. F8).

- Facies $\mathrm{C}$ is characterized by light gray to white clayrich nannofossil ooze and nannofossil-rich clay (Fig. F9). This facies is strongly bioturbated in most intervals and locally appears to be structureless.

- Facies D is characterized by light greenish gray to light gray bioturbated diatom-bearing to diatomrich silty clay and clay-rich diatom ooze (Fig. F9). This facies commonly has dispersed gravel-sized clasts and is moderately to strongly bioturbated. Burrows as wide as $\sim 2 \mathrm{~cm}$ are present throughout and are commonly pyritized.

- Facies E consists of olive-gray laminated clay (Fig. F9). This facies has common parallel laminations of silt and fine sand or displays a horizontal planar fissility where lithified. Bioturbation is sparse and consists of millimeter-scale (as large as $0.5 \mathrm{~cm}$ ) burrows. Gravel-sized clasts are rare.

\section{Unit descriptions}

Based on the distribution of lithofacies, the sedimentary succession recovered at Site U1361 is divided into two lithostratigraphic units (Fig. F3). Unit II is further distinguished from Unit I by a distinct change in color, degree of bioturbation, and lamination frequency.

\section{Unit I}

Interval: 318-U1361A-1H-1, $0 \mathrm{~cm}$, through $4 \mathrm{H}-5$, $88 \mathrm{~cm}$

Depth: 0-34.9 mbsf

Age: Pleistocene

Unit I is composed of interbedded and structureless light yellowish brown diatom-rich clays (Facies A) and light greenish gray silty clays (Facies B). The silty clays contain common foraminifers and fish fragments. Nannofossils occur in a silty clay interval with foraminifers in a smear slide from Sample 318U1361A-3H-5, $147 \mathrm{~cm}$. Sand and silt interbeds (as thick as $8 \mathrm{~cm}$ ) and rare packages of silt and clay laminations (as thick as $\sim 35 \mathrm{~cm}$ ) are present. Concentrations of granules and pebble-sized igneous and metamorphic clasts were observed as well.

\section{Interpretation}

The mixed terrigenous and biogenic components in Unit I indicate hemipelagic deposition. The sets of silt and clay laminations were probably deposited by low-density turbidity currents or saline density flows with traction transport, although a contour current origin is possible as well. The sand and silt interbeds could be derived from turbidity currents or sandy debris flows, but they may also represent lag deposits formed by current scouring. The presence of foraminifers and nannofossils suggests the site maintained a position above the calcite compensation depth, at least during some time intervals. Ice rafting is indicated by the dispersed gravel.

\section{Unit II}

\section{Subunit Ila}

Interval: 318-U1361A-4H-5, $88 \mathrm{~cm}$, through 34X$2,14 \mathrm{~cm}$ 
Depth: 34.9-313.2 mbsf

Age: late Miocene-Pliocene

\section{Subunit IIb}

Interval: 318-U1361A-34X-2, $14 \mathrm{~cm}$, to $41 \mathrm{X}-6$, $14 \mathrm{~cm}$

Depth: 313.2-388.0 mbsf

Age: late Miocene

Unit II is characterized by meter-scale alternation of laminated olive-gray silty clay (Facies E) and bioturbated greenish gray diatom-rich silty clay (Facies D) with minor diatom and nannofossil ooze and nannofossil-rich/nannofossil-bearing silty clays (Facies C). Some calcareous beds in the lower part of the unit are micritic and contain only trace amounts of preserved calcareous nannofossils. The olive-gray silty clays are characterized by parallel silt laminations or horizontal planar fissility. Bioturbation is sparse and mainly composed of millimeter-scale burrows. The greenish gray diatom-rich silty clays are commonly bioturbated with burrows as wide as $2 \mathrm{~cm}$. The nannofossil-bearing lithologies are strongly bioturbated. Clasts are more common in the diatomand nannofossil-rich facies than in the olive-gray silty clays. Conspicuous green laminations, with as large as sand-sized green minerals (possibly glauconite) are observed below 155 mbsf (Fig. F9).

Subunit IIa is distinguished from Subunit IIb by the occurrence of nannofossil-bearing and micritic lithologies (Facies C) in Subunit IIb (Fig. F3). The interbedded bioturbated light greenish gray silty clays (Facies D) and laminated olive-gray claystones (Facies E) within Subunit IIb are similar to those observed in Subunit IIa. However, in Subunit IIb the light greenish gray bioturbated facies generally have a lower diatom abundance (diatom-bearing silty clays in Subunit IIb versus diatom-rich silty clays in Subunit IIa). Within Subunit IIb, Facies C-E are arranged in decimeter- to meter-scale cycles with sparsely bioturbated, sharp-based, planar-bedded olive-gray claystones at the base grading upward into moderately bioturbated, light greenish gray diatom-bearing claystones with light gray to white strongly bioturbated nannofossil-bearing clays at the top (Fig. F9).

\section{Interpretation}

The cyclic nature of sedimentation of Facies C-E likely represents alternating deposition from contour currents or downslope currents with minor traction (e.g., saline density flows or turbid plumes) and hemipelagic sedimentation. Differences in bioturbation intensity of the facies may result from changes in bottom water oxygenation. The dispersed gravel in Facies $\mathrm{C}$ and $\mathrm{D}$ indicates ice rafting. The higher concentrations of gravel in the nannofossil- and diatom-bearing facies (Facies $\mathrm{C}$ and $\mathrm{D}$ ), as compared to the claystones (Facies $\mathrm{E}$ ), could result from lower background sedimentation rates of fine-grained terrigenous material. Alternatively, greater calving rates or melt rates of icebergs in association with higher sea-surface temperatures coincident with hemipelagic sedimentation could have produced the larger gravel component.

\section{Biostratigraphy}

Samples 318-U1361A-1H-CC through 41X-CC (1.5$386.31 \mathrm{mbsf}$ ) were analyzed for microfossils. Siliceous microfossils (diatoms, radiolarians, silicoflagellates, and sponge spicules), palynomorphs (e.g., dinoflagellate cysts [dinocysts] and sporomorphs), planktonic and benthic foraminifers, and calcareous nannofossils were recorded in Hole U1361A. In addition, Samples 318-U1361B-1H-CC (2.64 mbsf) and 2H-CC (12.00 mbsf) were analyzed for diatoms.

The abundance data of siliceous microfossils, palynomorphs, calcareous nannofossils, and foraminifers are summarized in Figure F10. Diatoms and radiolarians are present throughout the recovered intervals in variable preservation (Table T2), whereas calcareous nannofossils are abundant in discrete intervals (calcareous nannofossil oozes) in Hole U1361A (Table T3; see "Lithostratigraphy"). Palynomorphs are present in all ten samples processed for palynology, with half of them yielding trace to few non-age diagnostic dinocysts with poor to moderate preservation, whereas well-preserved, likely reworked sporomorphs (Table T4) were found in each sample. Planktonic and benthic foraminifers are either absent or occur in low abundance except in two samples, 318-U1361A2H-CC (19.04 mbsf) and 34X-CC (321.07 mbsf) where they are diverse and relatively abundant (Table T5).

Diatoms and radiolarians provide good biostratigraphic control for Hole U1361A, resolving an uppermost middle Miocene through uppermost Pleistocene sedimentary succession with no major breaks in sedimentation (Fig. F4). Magnetostratigraphy is in good agreement with biostratigraphy (see "Paleomagnetism"). All index events (biostratigraphy and magnetostratigraphy) are compiled in Table T6.

\section{Siliceous microfossils}

The sediments recovered from Site U1361 contain well-preserved and abundant biogenic silica dominated by diatoms and radiolarians, with variable abundances of silicoflagellates and sponge spicules (Table T2; Fig. F10). Diatoms and radiolarians provide the primary biostratigraphic control, resolving an uppermost middle Miocene through uppermost 
Pleistocene sedimentary succession, which appears to be complete. Diatom assemblages are dominated by typical Neogene Southern Ocean open-water forms with variable abundances of benthic, neritic, and sea ice-associated diatom taxa, indicating a high-nutrient, high-productivity sea ice-influenced setting throughout the depositional history of Site U1361. Moderate reworking of middle Miocene sediments into younger strata is exemplified by trace occurrences of the index diatoms Actinocyclus ingens var. nodus and $A$. ingens var. ovalis (Table T2). Fluctuations in the abundance of marine benthic and tychopelagic taxa such as Cocconeis spp., Diploneis spp., Paralia sulcata, stephanopyxids, and Trinacria excavata may indicate episodic transport of shelfal material to the drill site.

\section{Diatoms}

Diatoms are few to abundant above $349.99 \mathrm{mbsf}$ (Sample 318-U1361A-37X-CC) but rare to few below this level to the bottom of Hole U1361A (386.31 mbsf) (Table T2). In Hole U1361B they are few to common (Table T2). A clear succession of index species (e.g., Cody et al., 2008) was recognized throughout Hole U1361A (Fig. F4; Table T6) and in the two cores recovered from Hole U1361B. Samples 318-U1361A$1 \mathrm{H}-\mathrm{CC}$ through $4 \mathrm{H}-\mathrm{CC}$ (9.03-36.53 mbsf) are assigned to the Pleistocene, Samples 5H-CC through $13 \mathrm{H}-\mathrm{CC}$ (47.42 to $122.37 \mathrm{mbsf}$ ) to the Pliocene, and Samples $14 \mathrm{H}-\mathrm{CC}$ through $41 \mathrm{X}-\mathrm{CC}(\sim 132.57-386.31 \mathrm{mbsf})$ to the late middle to late Miocene.

\section{Pleistocene}

Seven diatom datums were recognized in Samples 318-U1361A-1H-CC through 4H-CC (9.03-36.53 mbsf) (Table T6):

- Last occurrence (LO) of

- Actinocyclus ingens (0.54 Ma),

- Thalassiosira elliptipora (0.68 Ma),

- Thalassiosira fasciculata (0.89 Ma),

- Fragilariopsis barronii (1.24 Ma), and

- Rouxia antarctica (1.50 Ma) and

- First occurrence (FO) of

- Fragilariopsis separanda (1.41 Ma) and

- Fragilariopsis obliquecostata (1.70 Ma).

\section{Pliocene}

Eleven diatom datums were recognized in Samples $318-U 1361 \mathrm{~A}-5 \mathrm{H}-\mathrm{CC}$ through $13 \mathrm{H}-\mathrm{CC} \quad(47.42$ to $\sim 122.57$ mbsf) (Table T6):

- LO of

- Thalassiosira insigna (2.48 Ma),

- Fragilariopsis weaveri (2.49 Ma), and

- Thalassiosira inura (2.54 Ma) and
- FO of

- Thalassiosira elliptipora (2.03 Ma),

- Fragilariopsis kerguelensis (2.20 Ma),

- Thalassiosira vulnifica (3.15 Ma),

- T. insigna (3.25 Ma),

- F. weaveri (3.53 Ma),

- F. barronii (4.40 Ma),

- T. inura (4.74 Ma), and

- Shionodiscus oestrupii (4.88 Ma).

\section{Miocene}

Twelve diatom datums were recognized in Samples 318-U1361A-14H-CC through 41X-CC ( 132.57$386.31 \mathrm{mbsf}$ ) (Table T6):

- LO of

- Thalassiosira miocenica (5.91 Ma),

- Fragilariopsis donahuensis (5.98 Ma),

- Thalassiosira mahoodii (6.85 Ma; Winter and Iwai, 2002),

- Denticulopsis ovata (9.64 Ma), and

- Denticulopsis dimorpha var. areolata (10.25 Ma);

- Last abundant occurrence (LAO) of

- Denticulopsis simonsenii (8.63 Ma) and

- D. dimorpha s.l. (10.78 Ma); and

- FO of

- Thalassiosira oliverana (6.18 Ma),

- Thalassiosira torokina (7.23 Ma),

- T. miocenica (7.29 Ma),

- T. mahoodii (8.47 Ma; Winter and Iwai, 2002), and

- D. dimorpha s.l. (12.50 Ma).

\section{Silicoflagellates and sponge spicules}

Silicoflagellates, sponge spicules, and radiolarian fragments occur sporadically in trace abundances in Hole U1361A (Table T2), and none were recorded in samples from Hole U1361B.

\section{Radiolarians}

A typical Neogene Southern Ocean radiolarian fauna is preserved in samples from Holes U1361A and U1361B. Specimens are well preserved to moderately well preserved, and abundance varies throughout the hole (Fig. F10).

The FOs of Helotholus vema (4.2 Ma) and Acrosphaera? labrata $(7.8 \mathrm{Ma})$ fall within the interval between Samples 318-U1361A-11H-CC and 12H-CC (104.26$111.32 \mathrm{mbsf}$ ) and between Samples 20X-CC and 22X-CC (184.41-205.21 mbsf), respectively. Samples 24X-CC (219.12 mbsf) and 25X-CC (234.82 mbsf) contain only few radiolarian specimens; therefore, the LO of Cycladophora spongothorax $(9.1 \mathrm{Ma})$ is constrained to the interval between Samples 23X-CC and 26X-CC (215.85-244.24 mbsf). The evolutionary 
transition of Acrosphaera murrayana to Acrosphaera australis (10.4 Ma) occurs within the interval between Samples 30X-CC and 31X-CC (273.55-283.09 mbsf) (Table T6).

\section{Calcareous nannofossils}

Hole U1361A contains nannofossil ooze beds and nannofossil-rich/-bearing silty clays (see "Lithostratigraphy"). Nannofossils are particularly abundant and well preserved between 313.60 and $341.62 \mathrm{mbsf}$ (Fig. F10). A nannofossil-bearing clay occurs at 269.53 mbsf, and limestone (containing calcareous nannofossils) occurs between 371.67 and $374.97 \mathrm{mbsf}$ (see "Lithostratigraphy"). Some of these calcareous beds are micritic and contain only trace amounts of nannofossils (see "Lithostratigraphy"). For the 313.60-341.62 mbsf interval, calcareous nannofossils are very abundant to common (Table T3). The assemblage is characterized by low diversity, mainly comprising Reticulofenestra pseudoumbilicus, Reticulofenestra minuta, and Reticulofenestra minutula (whereby closed central area morphotypes are dominant, e.g., Reticulofenestra gelida, Dictyococcites antarcticus, and Dictyococcites productus), characteristic of the late Miocene-early Pliocene from high latitudes. No standard biozonal markers were found.

\section{Palynology}

Ten core catcher samples from Hole U1361A were processed for palynology. All samples yielded palynomorphs. The palynological data are presented in Table T4.

\section{Dinocysts}

Only five samples from Hole U1361A yielded dinocysts, with abundances varying between trace and few. Dinocyst preservation is poor to moderate. Dinocyst assemblages within these samples consist mainly of protoperidinioid taxa (Brigantedinium spp. and Selenopemphix spp.). A taxon herein referred to as "Impagidinium brown" (see "Biostratigraphy" in the "Site U1359" chapter for details) occurs in trace amounts. No dinocyst index species were recorded. The dominance of protoperidinioid (i.e., heterotrophic) taxa suggests high sea-surface productivity, probably associated with sea ice ecosystems similar to the modern Southern Ocean (compare e.g., Esper and Zonneveld, 2007).

The palynomorph signal from cores from Site U1361 correlates well with those of Site U1359, with increasing dinocyst abundance and preservation in the Miocene and presence of "Impagidinium brown" in lower upper and middle Miocene sediments (Table T4; see "Biostratigraphy" in the "Site U1359" chapter).

\section{Sporomorphs}

Sporomorphs are abundant in all samples investigated from Hole U1361A, and the assemblage mainly consists of well-preserved spores and (saccate) pollen. The sporomorphs are reworked from Paleogene, Mesozoic, and/or Paleozoic strata. Sporomorph genera identified include Baculatisporites/Osmundacidites spp., Cicatricosisporites spp., Classopollis/Corollina spp., Deltoidospora/Triletes spp., Ischyosporites spp., Lycopodiacidites spp., and Nothofagus sp. Other palynofacies components were found in trace amounts only.

\section{Foraminifers}

Twenty-five samples from Hole U1361A were examined for foraminifers (Table T5). Foraminifers are either absent or occur in low abundances and low diversity except in two samples: 318-U1361A-2H-CC (19.04 mbsf) and 34X-CC (321.07 mbsf). The washed residue from Sample $2 \mathrm{H}$-CC contains $>90 \%$ planktonic foraminifers. Sample 34X-CC (321.07 mbsf) contains a relatively rich benthic foraminifer assemblage, with few poorly preserved planktonic foraminifers.

\section{Planktonic foraminifers}

Sample 318-U1361A-2H-CC (19.04 mbsf) contains abundant planktonic foraminifers, including Neogloboquadrina pachyderma and Globigerina bulloides. Neogloboquadrina pachyderma comprises $>80 \%$ of the assemblage in this sample. It also occurs sporadically between Samples 318-U1361A-3H-CC and 22X-CC (28.26-205.21 mbsf). Based on the presence of $N$. pachyderma and using the sub-Antarctic zonal scheme of Berggren (1992), the upper $205.21 \mathrm{mbsf}$ of Site U1361 can be assigned to sub-Antarctic Zone AN7, which ranges from 9.2 Ma to the present (Gradstein et al., 2004). A few planktonic foraminifers were also recorded from Sample 318-U1361A-34X-CC (321.07 mbsf). However, it was not possible to determine the specimens because of their poor preservation. Specimens of Neogloboquadrina nympha (FO at 13.4 Ma; LO 10.1 Ma) were identified in Sample 318U1361A-35X-CC (331.03 mbsf), constraining the age of this sample to between 13.4 and 10.1 Ma.

\section{Benthic foraminifers}

Benthic foraminifers are either absent or in low abundance at Site U1361, except for Samples 318-U1361A2H-CC (19.04 mbsf) and 34X-CC (321.07 mbsf). Sample 2H-CC (19.04 mbsf) contains a diverse assemblage of benthic foraminifers dominated by Ordorsalis tener (70\%). This assemblage is similar to those recovered from core-top material from deepwater sites between Antarctica and Australia that are associated with cold $\left(-0.2^{\circ}\right.$ to $\left.+0.4^{\circ} \mathrm{C}\right)$ Antarctic 
Bottom Water (Corliss, 1979). Sample 318-U1361A34X-CC (321.07 mbsf) contains a diverse assemblage of benthic foraminifers comprising Cibicidoides bradyi (31\%), Planulina renzi (12\%), Laticarina pauperata $(12 \%)$, and the agglutinated species Bolivinopis rosula (19\%). This benthic foraminifer assemblage is similar to benthic foraminifer assemblages of late Miocene age recovered from cores drilled at Kerguelen Plateau (Mackensen, 1992).

\section{Age model and sedimentation rates}

Here we summarize and integrate the biostratigraphic interpretations inferred from the individual microfossil groups. The resulting integrated age-depth model presented in Figure F4 and Table T6 also incorporates magnetostratigraphic age constraints presented in "Paleomagnetism." An upper middle Miocene (12.50 Ma) through uppermost Pleistocene (0.54 Ma) sedimentary succession was recovered from Hole U1361A. Sedimentation seems to be continuous throughout the record based on shipboard stratigraphic control. We divide the following sections according to sedimentation rate changes (Fig. F4).

\section{Late Miocene to Pleistocene (6.73-0.54 Ma)}

Diatoms and magnetostratigraphy resolve the sedimentary sequence for the Pleistocene in Hole U1361A (9.03-36.53 mbsf). The top of Hole U1361A is dated as latest Pleistocene (0.54 Ma). The Pliocene/ Pleistocene boundary $(1.81 \mathrm{Ma})$ is constrained by magnetostratigraphy and occurs at $\sim 33.58 \mathrm{mbsf}$, within Chron C2n. Further refinement of diatom biostratigraphy around this boundary interval is necessary (Fig. F4). Diatoms and magnetostratigraphy provide age control for the Pliocene sedimentary succession recovered from Hole U1361A (47.42$122.57 \mathrm{mbsf}$ ), with additional age constraints provided by radiolarians. Magnetostratigraphy and diatom bioevents are well correlated within this section. The Miocene/Pliocene boundary (5.33 Ma) is constrained by magnetostratigraphy and occurs at $\sim 134 \mathrm{mbsf}$, between the termination of Chron C3An.1n and the onset of Chron C3n.4n (Table T6). Sedimentation at Site U1361 appears to be continuous from the late Miocene through the Pleistocene at a variable rate, with lowest accumulation ( $14 \mathrm{~m} / \mathrm{m}$.y.) in the late Miocene and highest accumulation (as much as $38 \mathrm{~m} / \mathrm{m} . \mathrm{y}$.) in the early Pliocene. This $\sim 154 \mathrm{~m}$ long interval spans 6.19 m.y., yielding an average sedimentation rate of $25 \mathrm{~m} / \mathrm{m}$.y. (Fig. F4).

Late Miocene to middle Miocene (12.50-6.73 Ma) Miocene sediments from 153.8 to 314.64 mbsf were deposited with an average sedimentation rate of $37 \mathrm{~m} / \mathrm{m}$.y. (Fig. F4), given the magnetostratigraphic and biostratigraphic constraints. A change in sedimentation rates is inferred at 314.64 mbsf; average sedimentation rates within the section below this datum within latest middle to early late Miocene strata are $\sim 69 \mathrm{~m} / \mathrm{m} . \mathrm{y}$. (Fig. F4).

\section{Paleoenvironmental interpretation}

\section{Pleistocene}

Diatom assemblages from cores at Site U1361 are typical Neogene Southern Ocean open-water taxa with variable abundances of benthic, neritic, and sea ice-associated diatoms, indicating a high-nutrient, high-productivity, seasonally sea ice-influenced setting throughout the late Neogene depositional history at Site U1361. Moderate reworking of middle Miocene taxa into younger strata suggests continuous input of proximal sediments. High abundances of reworked sporomorphs within the palynological associations indicate continuous strong erosion in the hinterland. In situ dinocysts are absent.

\section{Pliocene}

As in the Pleistocene, Pliocene diatom assemblages are dominated by open-water taxa and variable abundances of benthic, neritic, and sea ice-associated taxa. Dinocyst assemblages are poor but mainly comprise heterotrophic taxa. This indicates that Pliocene biosiliceous-rich sediments were deposited in a pelagic, well-ventilated setting characterized by sea ice-influenced high productivity. High abundances of sporomorphs reworked from Paleogene, Mesozoic, and Paleozoic strata suggest continuous strong erosion in the hinterland.

\section{Latest middle Miocene and late Miocene}

Miocene diatom assemblages at Site U1361 are indicative of productive, seasonally variable open-marine conditions. Fluctuations in the abundance of marine benthic and tychopelagic taxa such as Cocconeis spp., Diploneis spp., P. sulcata, stephanopyxids, and T. excavata may indicate episodes of transportation of shelfal material to the drill site.

The presence of well-preserved calcareous nannofossils and benthic foraminifers suggests that the depositional setting was favorable for calcite preservation (i.e., not corrosive) for brief intervals in the Miocene. The presence of reworked Mesozoic-Paleozoic sporomorphs within the palynological associations suggests ongoing erosion in the hinterland.

\section{Paleomagnetism}

Paleomagnetic investigations at Site U1361 involved analysis of discrete samples from Hole U1361A and 
measurement of archive halves from Holes U1361A and U1361B. In general, we took 2-7 samples per core. A subset of these ( 45 samples) were subjected to step-wise alternating-field demagnetization. After measuring the natural remanent magnetization (NRM) of the archive halves, they were demagnetized at $20 \mathrm{mT}$. The anisotropy of magnetic susceptibility (AMS) was measured on all discrete samples. We constructed a polarity log from the inclinations of the archive halves and discrete samples and correlated this $\log$ to the geomagnetic polarity timescale (GPTS) of Gradstein et al. (2004), documenting a complete section from the top of Chron C2n to the top of Chron C3n. Below Chron C2n the recovered core is disturbed and we have not completed analysis of the discrete samples as of yet. The lower portion of Hole U1361A can plausibly be correlated to the bottom of Chron C5n to C5An.

\section{Analysis of discrete samples}

Selected discrete samples were measured and demagnetized in fields of 5, 10, 15, 20, and $30 \mathrm{mT}$ using the three-step protocol described in "Paleomagnetism" in the "Methods" chapter. The data were similar to those acquired at Site U1359 and were analyzed in the same manner.

\section{Analysis of archive halves}

We measured the NRM of archive halves from both holes (Fig. F11). Based on the step-wise demagnetization experiments, archive halves were demagnetized to $20 \mathrm{mT}$. Data after demagnetization to $20 \mathrm{mT}$ and edited for core disturbance are shown in Figure F12 for upper and lower parts of Hole U1361A and Hole $\mathrm{U} 1361 \mathrm{~B}$, respectively. In general, there is excellent agreement between the best-fit lines and those from the archive halves. Unfortunately, all cores below Core 318-U1361A-17X are highly disturbed by drilling and no measurements from the archive halves were deemed reliable. Discrete samples were taken from undisturbed portions so that they can provide some guide to the polarity stratigraphy.

\section{Anisotropy of magnetic susceptibility}

In addition to remanence analyses, we measured the AMS (including the bulk susceptibility, $\chi_{\mathrm{b}}$ ) on all discrete samples (Fig. F13). Samples were taken to avoid to the extent possible disturbed coring however a substantial number (those with $\mathrm{V}_{3}$ inclinations less than about $60^{\circ}$ and distinct maximum and intermediate eigenvalues) had characteristic disturbed fabrics.

There are two pronounced zones of very low bulk magnetic susceptibility (Fig. F13C), one at 190 mbsf, coincident with a zone of low remanent intensity
(Fig. F12) and a second at $\sim 300$ mbsf. These are apparently the same as the Pliocene and Miocene low-susceptibility zones recorded in cores from Site U1359.

\section{Correlation of magnetostratigraphy to geomagnetic polarity timescale}

We constructed a polarity log for Hole U1361A, as shown in Figure F12A and F12B, that can be correlated to the GPTS of Gradstein et al. (2004), shown to the right. Our correlation tie points are listed in Table T7.

\section{Geochemistry Organic geochemistry}

Gas analysis was performed typically once per core from Hole U1361A using the methods described in "Geochemistry and microbiology" in the "Methods" chapter.

Methane concentrations vary by four orders of magnitude downhole, from 2 to 15,363 ppmv (Fig. F14A). Concentrations are 2-3 ppmv in the uppermost $163 \mathrm{mbsf}$ and increase to $7,248 \mathrm{ppmv}$ at $240 \mathrm{mbsf}$. A maximum value of $15,363 \mathrm{ppmv}$ is reached at 355 mbsf. Methane levels from 364 to 381 mbsf are lower, with an average concentration of $\sim 8,500 \mathrm{ppmv}$. Ethane was detected below $216 \mathrm{mbsf}$, and $\mathrm{C}_{1} / \mathrm{C}_{2}$ levels are between 4,455 and 8,816 (Fig. F14B).

\section{Inorganic geochemistry}

Forty samples from Hole U1361A were taken for analyses of weight percent carbonate, carbon, nitrogen, and sulfur content, as well as major and trace element analyses. Samples were collected in close collaboration with the sedimentology group to sample the main lithologies represented. Because of technical problems with the ICP-AES, no major and trace element analyses could be obtained.

$\mathrm{CaCO}_{3}$ (in weight percent) was determined on all sediment samples by coulometric methods (see "Geochemistry and microbiology" in the "Methods" chapter). $\mathrm{CaCO}_{3}$ contents for most samples are well below detection limit $(<1 \mathrm{wt} \%)$ (Fig. F15). Between 313.96 and 342.04 mbsf, however, carbonate contents increase to $12.1-24.8 \mathrm{wt} \%$. This is in agreement with the description of nannofossil-bearing clays constituting one of three major facies below 313.2 mbsf (lithostratigraphic Subunit IIb; see "Lithostratigraphy").

Carbon, nitrogen, and sulfur contents were measured on 15 selected samples covering the full range of $\mathrm{CaCO}_{3}$ contents (0-24.8 wt\%). All concentration levels are very low (i.e., $\mathrm{C}<0.5 \mathrm{wt} \%, \mathrm{~N}<0.03 \mathrm{wt} \%$, 
and $\mathrm{S}<0.02 \mathrm{wt} \%$ ), except for the four samples with high calcium carbonate contents (Fig. F16). Taken together with the $\mathrm{CaCO}_{3}$ measurements, these samples yield total organic carbon concentrations below $0.3 \mathrm{wt} \%$, which is within the error or the respective measurements.

\section{Physical properties}

The physical properties program for Site U1361 encompassed routine runs on the WRMSL, which includes GRA density, magnetic susceptibility, and PWL sensors, as well as NGR measurements. $P$-wave velocity measurements were also analyzed and samples were taken and analyzed for moisture, density, and porosity. Thermal conductivity measurements were made in one section of all cores.

\section{Whole-Round Multisensor Logger measurements}

All Site U1361 cores were measured on the WRMSL (Figs. F17, F18).

\section{Magnetic susceptibility}

Whole-core magnetic susceptibility was measured at $2.5 \mathrm{~cm}$ intervals ( $2 \mathrm{~s}$ measurement time). Raw data values are generally $<200$ instrument units with peaks as high as $>500$ instrument units (3508 instrument units at maximum), interpreted to represent gravel clasts (Fig. F17). After removing obvious peaks caused by gravel clasts, the majority of measurements fall below 100 instrument units.

The magnetic susceptibility data exhibit relatively high amplitude variations, and apparent cyclicity at several scales occurs, especially in the uppermost $165 \mathrm{mbsf}$ and between 305 mbsf and the bottom of the hole. There are two intervals with reoccurring relatively lower magnetic susceptibility units between 165 and 185 mbsf and between 265 and 305 mbsf.

\section{Natural gamma radiation}

The total counts per second ranged from 8 to $62 \mathrm{cps}$, with the peaks interpreted to represent dispersed gravel clasts. However, the majority of measurements fall between 15 and $55 \mathrm{cps}$, and the record displays meter-scale variability, which is most likely related to variations in the relative amount of biogenous and terrigenous sediment components (Fig. F17).

\section{Gamma ray attenuation bulk density}

GRA bulk density was measured at $2.5 \mathrm{~cm}$ intervals on the WRMSL (10 s integration time). The measured values are as high as $2.58 \mathrm{~g} / \mathrm{cm}^{3}$ (Fig. F18). The variations in GRA density reflect the regular fluctuations in lithology and porosity. We note a slight increase with burial depth, consistent with compaction of the sediments by overburden. GRA bulk densities display meter-scale variability around an average value of $1.6 \mathrm{~g} / \mathrm{cm}^{3}$. An interval of lower density $\left(\sim 1.50 \mathrm{~g} / \mathrm{cm}^{3}\right)$ occurs between 22 and $40 \mathrm{mbsf}$, most likely indicating an interval of higher biosiliceous content.

\section{$P$-wave velocity}

$P$-wave velocity measurements were made at $5 \mathrm{~cm}$ intervals on the WRMSL for all cores. The raw values are as high as $3963 \mathrm{~m} / \mathrm{s}$, including data from dispersed gravel clasts (Fig. F19).

Discrete measurements of $P$-wave velocity were also made on the working halves of cores from Hole U1361A. Between Cores 318-U1361A-1H and 41X, single measurements of $P$-wave velocity were made using the Section Half Velocity Gantry. In unconsolidated sediments, down to Core 318-U1361A-15H, these consisted of a multiaxis $P$-wave velocity measurement per core section measuring $P$-wave velocity using the $P$-wave caliper for the $x$-direction and the $P$-wave bayonets for the $y$ - and $z$-directions. (Figs. F19, F20, F21). Starting with Core 318-U1361A-16H (142 mbsf), the sediments were too lithified to properly insert the bayonet transducers. From 142 mbsf downhole, discrete measurements were limited to the $x$-direction $P$-wave caliper. The measurements display variable amounts of acoustic anisotropy. Figure F20 shows a definite increase in $P$-wave velocities with depth. As a general trend, the $x$-axis $P$-wave velocity measurements exhibit the highest values, followed by the $y$-axis and then the $z$-axis measurements. The faster velocity measured parallel to the bedding ( $x$ - and $y$-axes) is probably a result of the relatively higher amount of clay (Fig. F21).

\section{Moisture and density measurements}

Measurements of moisture and density (MAD), porosity, and grain density were made on 143 samples. Depending on core recovery and quality, one sample was taken per section. These samples were carefully selected to cover the representative lithology of each core section and were taken in undisturbed sediments whenever possible. These samples were measured for wet mass, dry mass, and dry volume, and using these measurements, porosity, percent water mass, dry density, bulk density, and grain density were calculated.

Grain density varies between 2.22 and $2.98 \mathrm{~g} / \mathrm{cm}^{3}$ (Fig. F22). The wet bulk densities (MAD) from discrete samples range from 1.30 to $1.97 \mathrm{~g} / \mathrm{cm}^{3}$, and dry densities range from 0.48 to $1.53 \mathrm{~g} / \mathrm{cm}^{3}$ (Fig. F23). 
The relative moisture content varies between 63 and $22 \mathrm{wt} \%$, and porosity varies from $82 \%$ to $42 \%$, with a gradual decrease with increasing depth and overburden pressure (Figs. F22, F24).

A common feature of density, porosity, and water content records at Site U1361 is a slight change to higher gradients below 330 mbsf that occurs within lithostratigraphic Subunit IIb.

\section{Thermal conductivity}

Thermal conductivity was measured on one section per core for all cores from Hole U1361A. The thermal conductivity data slightly decrease with depth and are discussed in more detail in relation to downhole temperature measurements for calculating heat flow (Fig. F25) (see "Downhole measurements").

\section{Stratigraphic correlation and composite section}

Magnetic susceptibility, GRA density, and NGR data collected from cores from Holes U1361A and U1361B were used to construct a short composite section for Site U1361. The NGR and magnetic susceptibility measurements were primarily used for core to core correlation and to construct the composite section (Figs. F26, F27). The depth offsets that define the composite section for Site U1361 are given in Table T8.

Two cores were recovered from Hole U1361B. Core $318-\mathrm{U} 1361 \mathrm{~B}-1 \mathrm{H}$ is severely disturbed. Core 318U1361B-2H overlaps with Cores 318-U1361A-1H and $2 \mathrm{H}$ and covers an interval that is not well represented in the upper, disturbed part of Core 318U1261A-2H (Figs. F26, F27).

Following construction of the composite depth section for Site U1361, a single spliced record was assembled from the aligned core intervals from the two holes (Fig. F27). The composite data show that the cores from Site U1361 provide a continuous sequence from the seafloor to $\sim 19.3$ meters composite depth (bottom of Core 318-U1361A-2H). Below this depth, Cores 318-U1361A-3H through 41X were appended to the record (Figs. F26, F27; Table T9).

The Site U1361 splice can be used as a guide to sample the sedimentary sequence for the uppermost part of the site.

\section{Downhole measurements}

\section{Logging operations}

Downhole logging operations started after a successful reentry of Hole U1361A, which had been left temporarily to allow an iceberg to pass. $\mathrm{ACP} / \mathrm{XCB}$ coring had reached a total depth of 388.0 mbsf (drillers depth below seafloor [DSF]). In preparation for logging, the hole was flushed with a $50 \mathrm{bbl}$ sweep of sepiolite mud and then displaced with $179 \mathrm{bbl}$ of $10.5 \mathrm{ppg}$ barite-weighted mud. The pipe was pulled up to 103.2 mbsf (DSF). The drillers reported no problems with the hole. The logging plan for Hole U1361A was to run the triple combo tool string followed by the FMS-sonic tool string.

At $0725 \mathrm{~h}$ on 1 March 2010, the triple combo tool string (resistivity, density, porosity, and natural gamma ray sensors), with a go-devil at the bottom, was run into the hole and logged down to the bottom at 390 mbsf (wireline depth below seafloor). The hole was then logged up to seafloor. The tools provided continuous and good-quality log data. The hole was drilled with an 117/16 inch diameter APC/XCB bit and the diameter recorded by the caliper ranged from 12 to 15 inches $(30.5-38.1 \mathrm{~cm})$, with several thin washouts >16 inches shallower than 155 mbsf. The seafloor was identified at 3469.5 mbrf (wireline depth below rig floor) from an increase in gamma ray values at the sediment/water interface (Fig. F28). This seafloor depth is slightly deeper than the driller's mudline depth of 3465.5 mbrf (drilling depth below rig floor) probably because of wireline cable stretch, drill pipe stretch, tides, ship heave, and so on.

At $1725 \mathrm{~h}$, rig-up of the FMS-sonic tool string (FMS microresistivity imager, sonic, and NGR tools) was completed and the tool string was run down to the bottom of the hole (Fig. F28). Two upward passes were logged at 550 and $275 \mathrm{~m} / \mathrm{h}$, respectively. At the top of the second upward log, as the base of the tool string was entering the pipe the cable tension increased and the tool string had to be stopped and lowered again. After an hour of retrying to enter the pipe, initially without pumping water down and then with pumping, the tool string cleared the obstruction and passed back up fully into the pipe. The FMS-sonic tool string was then pulled up the pipe slowly, because large tension swings caused by ship heave (as much as $3 \mathrm{~m}$ ) made it impossible to increase the speed. The tools were back on the rig floor at $0405 \mathrm{~h}$ on 2 March.

\section{Logging units}

Downhole logs in Hole U1361A have high-amplitude, 1-5 $\mathrm{m}$ variability superimposed on a downhole compaction trend. The character of the logs changes gradually downhole, with no major steps in the base levels, so the entire logged interval was assigned to one logging unit (Fig. F29). The overall character and values of the logs are similar to those at Site U1359, $50 \mathrm{~km}$ to the south. 
NGR varies between 35 and 80 gAPI, with higher amplitude swings from 225 mbsf up to the pipe. Below $250 \mathrm{mbsf}$, there is a slight trend to lower NGR values downhole, but the $1-5 \mathrm{~m}$ variability remains. As at Site U1359, the NGR signal comes mostly from the radioactive isotopes of potassium and thorium (Fig. F30).

The density and resistivity logs also have highamplitude variability in the interval from $225 \mathrm{mbsf}$ up to the pipe. Density and sonic velocity have an increasing downhole trend, reflecting sediment compaction with depth. Resistivity, similar to that at Site U1359, shows the opposite trend (decreasing slightly downhole), possibly because of increasing temperature with depth. Resistivity would normally be expected to increase with depth.

Compressional wave velocity has good repeatability between the two passes below 170 mbsf, but from 170 mbsf to the pipe, velocities could not be determined from the real-time slowness-time-coherence analyses. In general, the logged velocities have higher values than those measured on the XCB cores ( $P$-wave caliper; $x$-direction), possibly because of the slightly disturbed nature of the $\mathrm{XCB}$ cores and log measurement under in situ conditions.

\section{Correlations between the downhole logs}

A change in the relationship between the natural gamma log and the physical properties logs occurs at $\sim 265$ mbsf (Fig. F31). From the pipe to $265 \mathrm{mbsf}$, all logs co-vary, with low NGR corresponding to lowdensity and low-resistivity values. As at Site U1359, this is most probably because the diatoms retain intragranular porosity because the opal they are made of has a low density and because the diatoms dilute the more radioactive clays and other terrigenous minerals that make up the balance of the sediment. In contrast, below 265 mbsf the resistivity log anticorrelates with the NGR log, and the density log has some features in common with both NGR and resistivity (Fig. F31). One possible explanation for this is that cementation is taking place preferentially in the diatom-rich layers, blocking the pore throats that allow electrical conduction and slightly increasing the bulk density but leaving the clay and terrigenous content of the layer unchanged. The appearance of calcareous nannofossils below 313 mbsf (see "Lithostratigraphy") could also have an additional influence, because calcite has a higher density $\left(\sim 2.7 \mathrm{~g} / \mathrm{cm}^{3}\right)$ than opal (2.1-2.2 $\left.\mathrm{g} / \mathrm{cm}^{3}\right)$, but this would not explain the higher resistivity values in the microfossil-rich layers. The implication is that levels of cementation increase in the microfossil-rich layers below 265 mbsf.

\section{Cyclicity}

Figure F31 illustrates the cyclic nature of the sediment sequence, which alternates between high and low log values at intervals of $1-5 \mathrm{~m}$. As a first rough estimate of the average duration of these alternations, the number of cycles in both of the intervals shown in Figure F31 was counted. For the 130-180 mbsf interval, there are $\sim 15$ alternations and the duration is, very approximately, 2 m.y. (see "Biostratigraphy"). This gives an average duration of 133 k.y. for each cycle, which seems to be in the ballpark of the orbital eccentricity Milankovitch cycle (96 and 125 k.y.). The 300-350 mbsf interval also contains 15 alternations, laid down over perhaps 1 m.y., giving an average duration of $67 \mathrm{k} . \mathrm{y}$. for each cycle. Given the uncertainties in the initial age estimates, the probability that all cycles are not recorded equally well in the sediment record, the possibility of multiple cyclicities influencing the sediment record, and the subjective nature of counting cycles, this early estimate requires further verification. It is certainly reasonable, however, that Milankovitch band variability at eccentricity and possibly obliquity periods is recorded at Site U1361.

\section{Formation MicroScanner resistivity images}

FMS resistivity images reveal stratigraphic information at a finer spatial resolution than the standard resistivity logs (Fig. F32A), including both gradual and sharp transitions between the alternations of resistive and conductive beds (Fig. F32B) and dropstones and ice-rafted debris larger than $\sim 0.5 \mathrm{~cm}$. The dropstones appear as resistive (light colored) spots in the image (Fig. F32C), and it will be possible to map their occurrence from 105 to 390 mbsf.

\section{Temperature measurements}

Downhole measurements at Site U1361 included four APCT-3 deployments in Hole U1361A (Table T10). During deployment in Cores 318-U1361A-4H and $13 \mathrm{H}$, the APCT-3 failed to couple properly with the formation and the recorded data could not be used. The measured temperatures ranged from $4.37^{\circ} \mathrm{C}$ at $66.0 \mathrm{mbsf}$ to $5.58^{\circ} \mathrm{C}$ at $94.5 \mathrm{mbsf}$ (Fig. F33A) and provide a linear geothermal gradient of $64.5^{\circ} \mathrm{C} / \mathrm{km}$ (Fig. F33B). The temperature at the seafloor was $-0.3^{\circ} \mathrm{C}$, based on the average of the measurements at the mudline during all APCT-3 deployments. The thermal conductivity under in situ conditions was estimated from laboratory-determined thermal conductivity using the method of Hyndmann et al. (1974) (see "Physical properties" in the "Methods" chapter). Considering the variations in thermal conductivity with depth, a measure of the heat flow in a conductive regime can be given by a "Bullard plot." Thermal resistance is then calculated by cumulatively adding the inverse of the in situ thermal conductivity values over depth intervals downhole. If the thermal regime is purely conductive, the heat 
flow will be the slope of the temperature versus the thermal resistance profile (Bullard, 1939). The thermal resistance calculated over the intervals overlying the APCT-3 measurements is shown in Table T10, and the resulting linear fit of the temperature gives the heat flow value of $58.2 \mathrm{~mW} / \mathrm{m}^{2}$ (Fig. F33C).

\section{References}

Barker, P.F., Camerlenghi, A., Acton, G.D., et al., 1999. Proc. ODP, Init. Repts., 178: College Station, TX (Ocean Drilling Program). doi:10.2973/odp.proc.ir.178.1999

Berggren, W.A., 1992. Neogene planktonic foraminifer magnetobiostratigraphy of the southern Kerguelen Plateau (Sites 747, 748, and 751). In Wise, S.W., Jr., Schlich, R., et al., Proc. ODP, Sci. Results, 120: College Station, TX (Ocean Drilling Program), 631-647. doi:10.2973.odp.proc.sr.120.153.1992

Bullard, E.C., 1939. Heat flow in South Africa. Proc. R. Soc. London, Ser. A, 173(955):474-502. doi:10.1098/ rspa.1939.0159

Cody, R.D., Levy, R.H., Harwood, D.M., and Sadler, P.M., 2008. Thinking outside the zone: high-resolution quantitative diatom biochronology for the Antarctic Neogene. Palaeogeogr., Palaeoclimatol., Palaeoecol., 260(12):92-121. doi:10.1016/j.palaeo.2007.08.020

Corliss, B.H., 1979. Recent deep-sea benthonic foraminiferal distributions in the southeast Indian Ocean: inferred bottom-water routes and ecological implications. Mar. Geol., 31(1-2):115-138. doi:10.1016/ 0025-3227(79)90059-8

De Santis, L., Brancolini, G., and Donda, F., 2003. Seismostratigraphic analysis of the Wilkes Land Continental Margin (East Antarctica): influence of glacially driven processes on the Cenozoic deposition. Deep-Sea Res., Part II, 50(8-9):1563-1594. doi:10.1016/S09670645(03)00079-1

Donda, F., Brancolini, G., De Santis, L., and Trincardi, F., 2003. Seismic facies and sedimentary processes on the continental rise off Wilkes Land (East Antarctica): evidence of bottom current activity. Deep-Sea Res., Part II, 50(8-9):1509-1527. doi:10.1016/S09670645(03)00075-4

Escutia, C., Brinkhuis, H., and Klaus, A., 2008. Cenozoic East Antarctic ice sheet evolution from Wilkes Land margin sediments. IODP Sci. Prosp., 318. doi:10.2204/ iodp.sp.318.2008

Escutia C., De Santis, L., Donda, F., Dunbar, R.B., Cooper, A.K., Brancolini, G., and Eittreim, S.L., 2005. Cenozoic ice sheet history from East Antarctic Wilkes Land Continental Margin sediments. Global Planet. Change, 45(13):51-81. doi:10.1016/j.gloplacha.2004.09.010

Escutia, C., Eittreim, S.L., and Cooper, A.K., 1997. Cenozoic sedimentation on the Wilkes Land continental rise, Antarctica. In Ricci, C.A. (Ed.), The Antarctic Region: Geological Evolution and Processes. Proc. Int. Symp. Antarct. Earth Sci., 7:791-795.
Escutia, C., Eittreim, S.L., Cooper, A.K., and Nelson, C.H., 2000. Morphology and acoustic character of the Antarctic Wilkes Land turbidite systems: ice-sheet-sourced versus river-sourced fans. J. Sediment. Res., 70(1):84-93. doi:10.1306/2DC40900-0E47-11D78643000102C1865D

Escutia, C., Nelson, C.H., Acton, G.D., Eittreim, S.L., Cooper, A.K., Warnke, D.A., and Jaramillo, J.M., 2002. Current controlled deposition on the Wilkes Land continental rise, Antarctica. In Stow, D.A.V., Pudsey, C.J., Howe, J.A., Faugeres, J.-C., and Viana, A.R. (Eds.), Deep-Water Contourite Systems: Modern Drifts and Ancient Series, Seismic and Sedimentary Characteristics. Mem.Geol. Soc. London, 22(1):373-384. doi:10.1144/ GSL.MEM.2002.022.01.26

Esper, O., and Zonneveld, K.A.F., 2007. The potential of organic-walled dinoflagellate cysts for the reconstruction of past sea-surface conditions in the Southern Ocean. Mar. Micropaleontol., 65(3-4):185-212. doi:10.1016/j.marmicro.2007.07.002

Gradstein, F.M., Ogg, J.G., and Smith, A. (Eds.), 2004. A Geologic Time Scale 2004: Cambridge (Cambridge Univ. Press). http://cambridge.org/uk/catalogue/catalogue.asp?isbn=9780521781428

Hyndman, R.D., Erickson, A.J., and Von Herzen, R.P., 1974. Geothermal measurements on DSDP Leg 26. In Davies, T.A., Luyendyk, B.P., et al., Init. Repts. DSDP, 26: Washington, DC (U.S. Govt. Printing Office), 451-463. doi:10.2973/dsdp.proc.26.113.1974

Mackensen, A., 1992. Neogene benthic foraminifers from the southern Indian Ocean (Kerguelen Plateau): biostratigraphy and paleoecology. In Wise, S.W., Jr., Schlich, R., et al., Proc. ODP, Sci. Results, 120: College Station, TX (Ocean Drilling Program), 649-673. doi:10.2973/ odp.proc.sr.120.167.1992

O’Brien, P.E., Cooper, A.K., Richter, C., et al., 2001. Proc. ODP, Init. Repts., 188: College Station, TX (Ocean Drilling Program). doi:10.2973/odp.proc.ir.188.2001

Rebesco, M., Camerlenghi, A., Geletti, R., and Canals, M., 2006. Margin architecture reveals the transition to the modern Antarctic ice sheet (AIS) ca. 3 Ma. Geology, 34(4):301-304. doi:10.1130/G22000.1

Stow, D.A.V., and Piper, D.J.W., 1984. Deep-water finegrained sediments: facies models. In Stow, D.A.V., and Piper, D.J.W. (Eds.), Fine-Grained Sediments: Deep-Water Processes and Facies. Geol. Soc. Spec. Publ., 15(1):611646. doi:10.1144/GSL.SP.1984.015.01.38

Winter, D., and Iwai, M., 2002. Data report: neogene diatom biostratigraphy, Antarctic Peninsula Pacific margin, ODP Leg 178 rise sites. In Barker, P.F., Camerlenghi, A., Acton, G.D., and Ramsay, A.T.S. (Eds.), Proc. ODP, Sci. Results, 178: College Station, TX (Ocean Drilling Program), 1-25. doi:10.2973/odp.proc.sr.178.230.2001

Publication: 2 July 2011 MS 318-109 
Figure F1. Bathymetric map of eastern Wilkes Land margin showing the location of Site U1361. Bold line = multichannel seismic reflection profile shown in Figure F2.

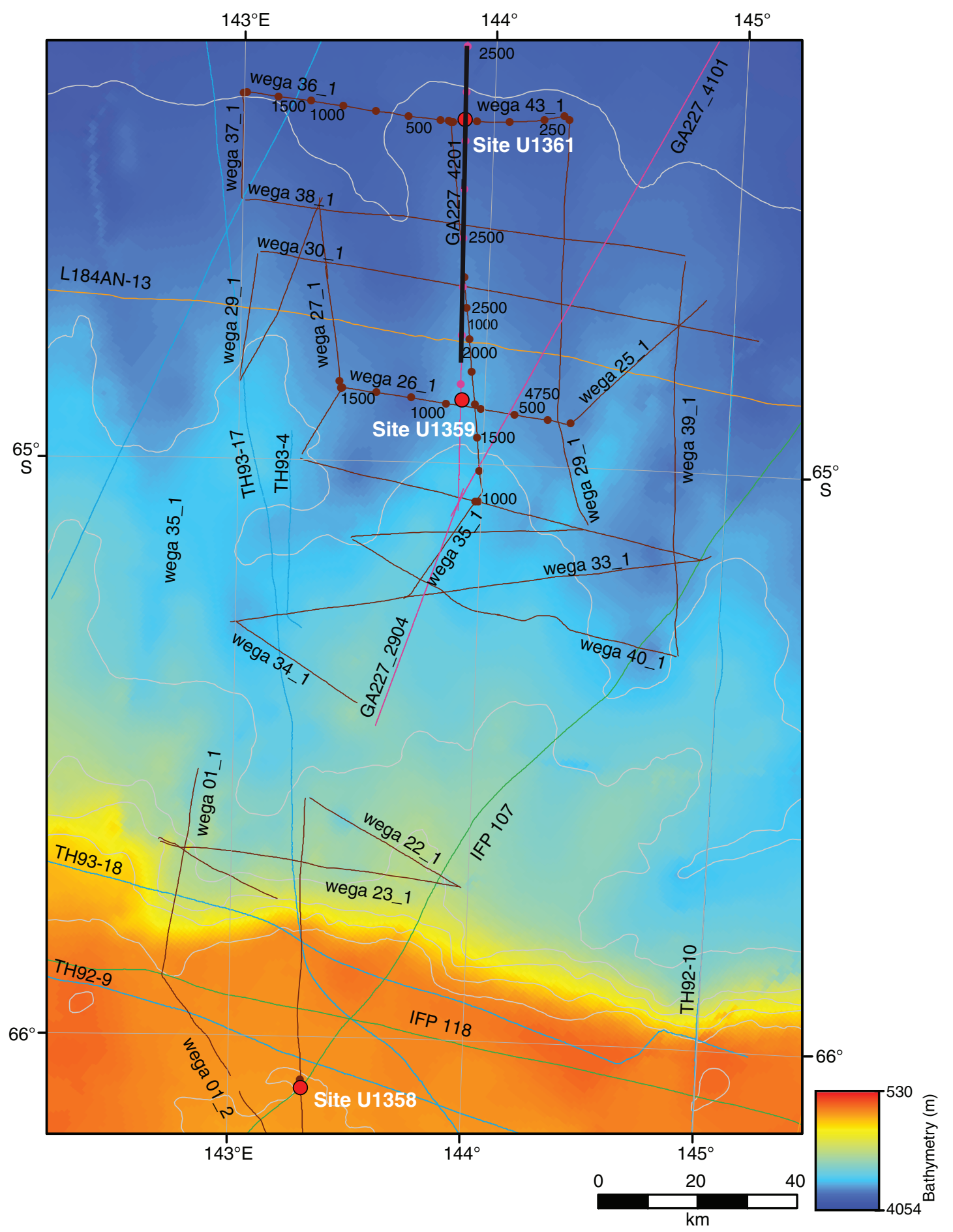


Figure F2. Multichannel seismic reflection profile across Site U1361 showing regional Unconformities WLU5-WLU8 targeted by drilling. Red rectangle = approximate penetration achieved at Site U1361. Location of seismic profile is shown in Figure F1.

GA227 4201

SE

1800

1900

2000

Shotpoint

2200

2100

2400

2500

2600

WEGA 43_01

SP 829

4.5

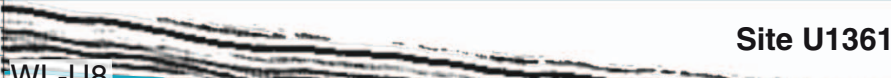

$\mathrm{WL}-\mathrm{U} 8 \cong \mathrm{NON}=$

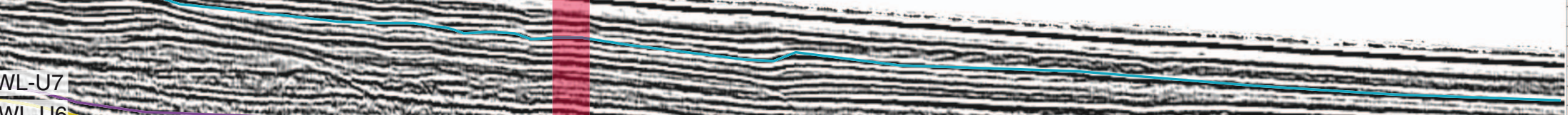

WL-U6N

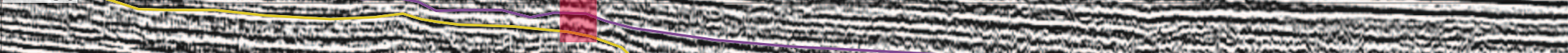

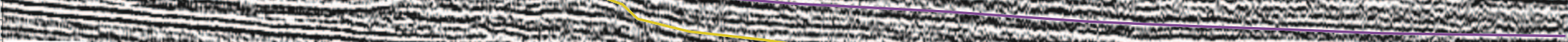
WL-U5b

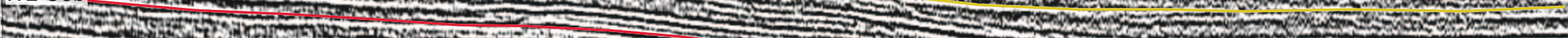
E.

5.5 l. 
Figure F3. Summary lithologic log, Site U1361.

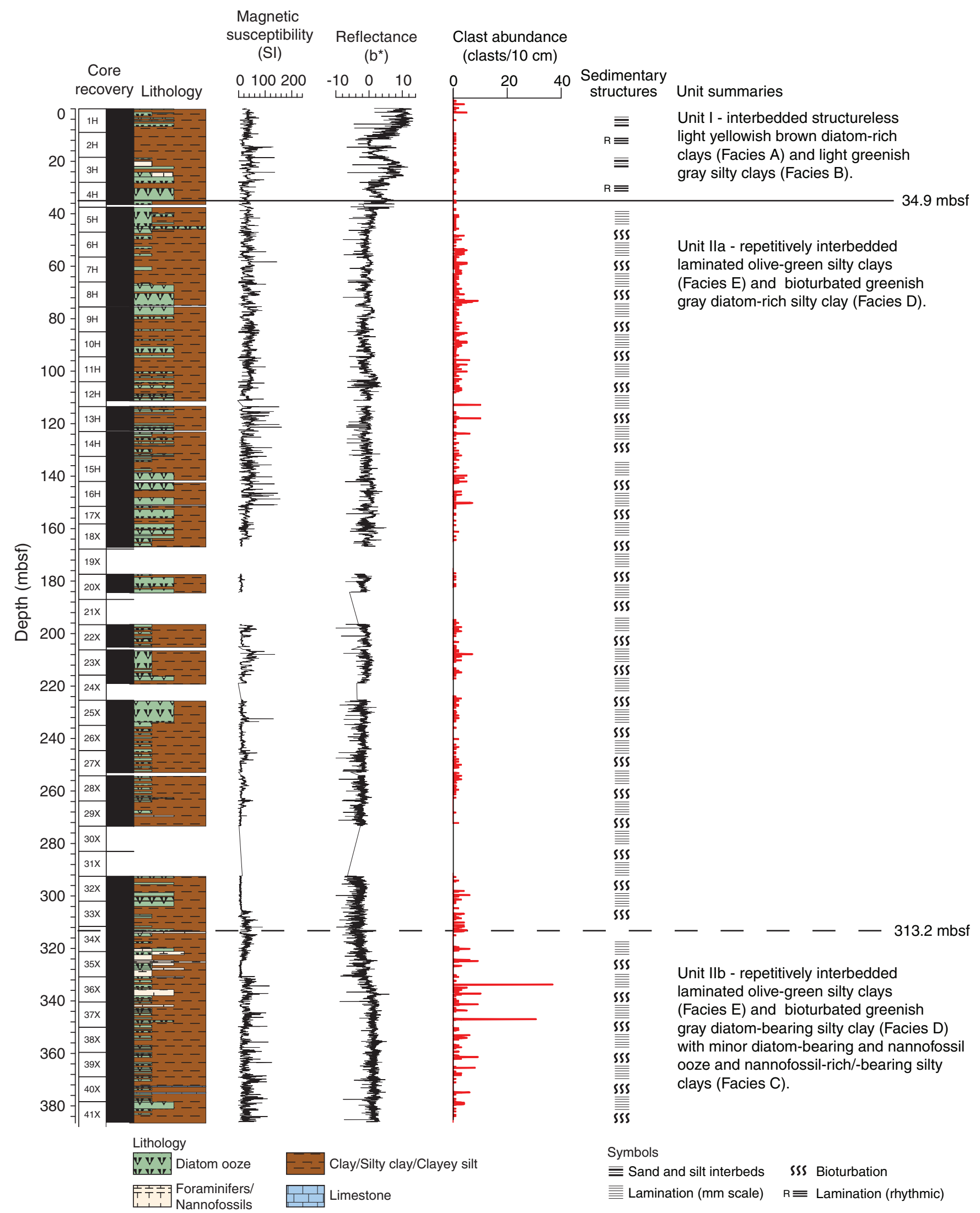


Figure F4. Biomagnetostratigraphic age-depth plot, Hole U1361A. Yellow shading = chronostratigraphic preservation. Microfossil datums are plotted by using the median depth between upper and lower samples (Table T6). Mid-point absolute age in the average range model of Cody et al. (2008) is used for the diatom datums. $t=$ top, $b=$ bottom, $o=$ oldest, $y=$ youngest. Blue line $=$ best-fit sedimentation rate.
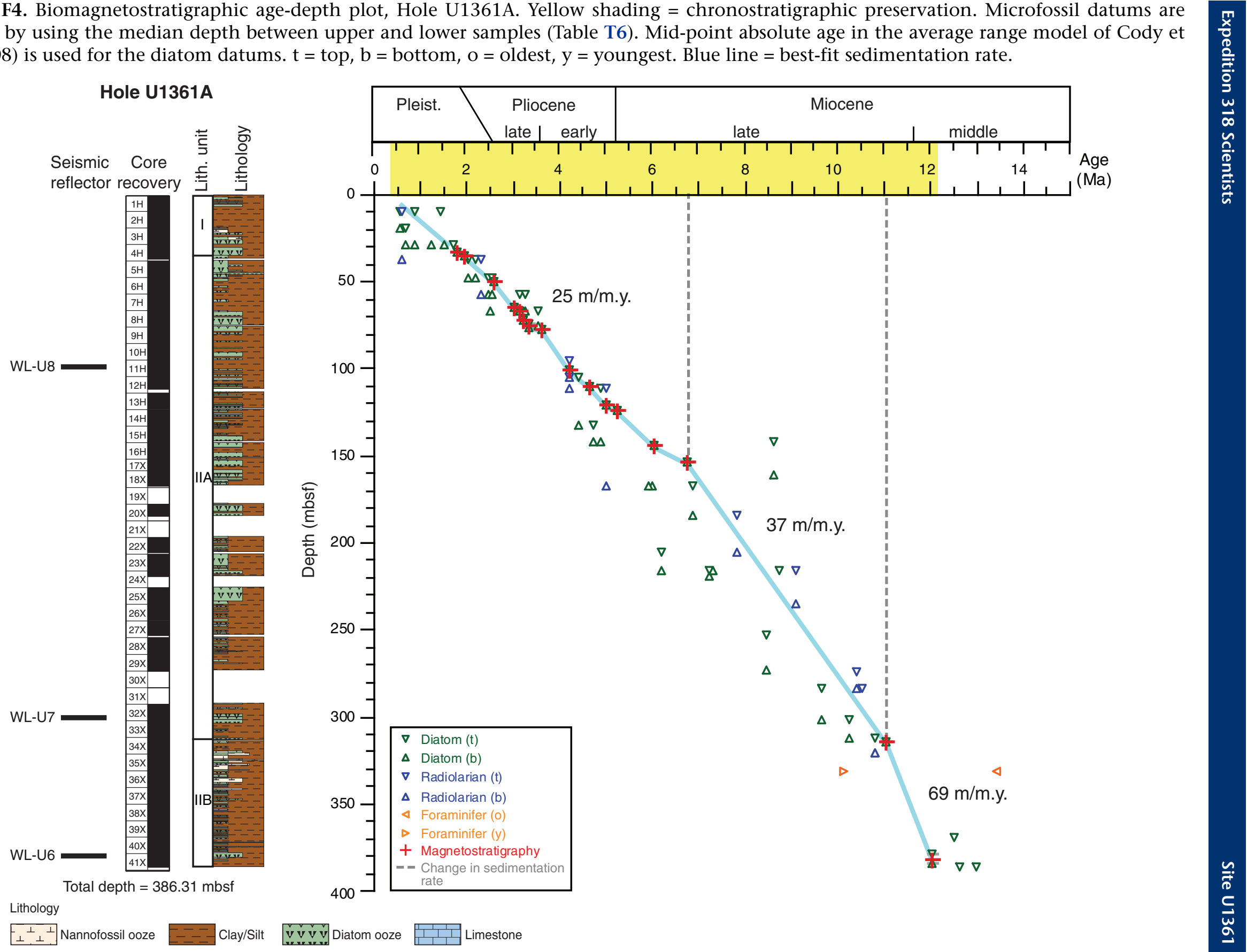
Figure F5. Downhole compositional changes from smear slide data, Site U1361.

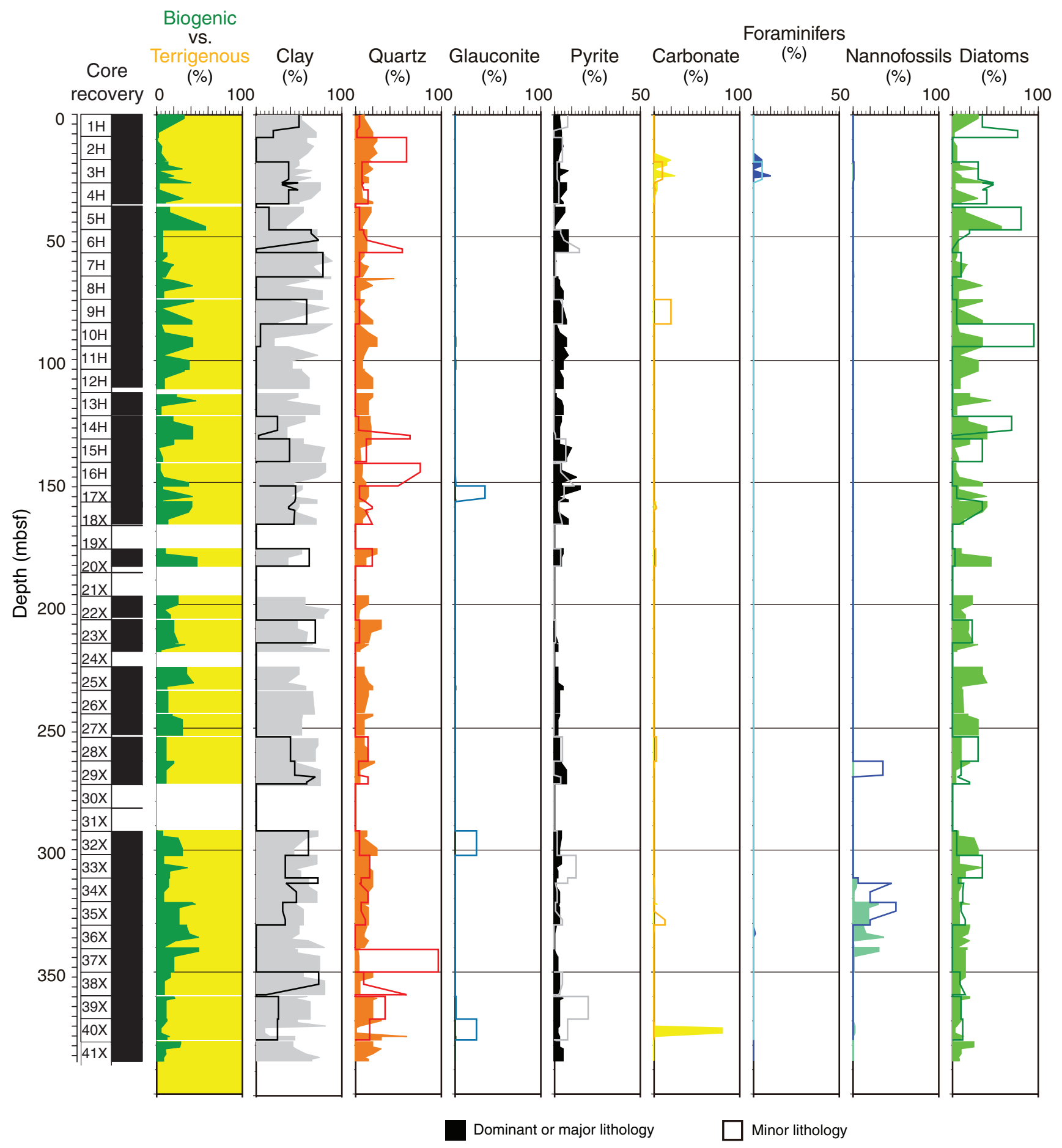


Figure F6. Core image of light yellowish brown diatom-rich clay in Facies A, Hole U1361A (interval 318U1361A-1H-1, 26-44 cm).

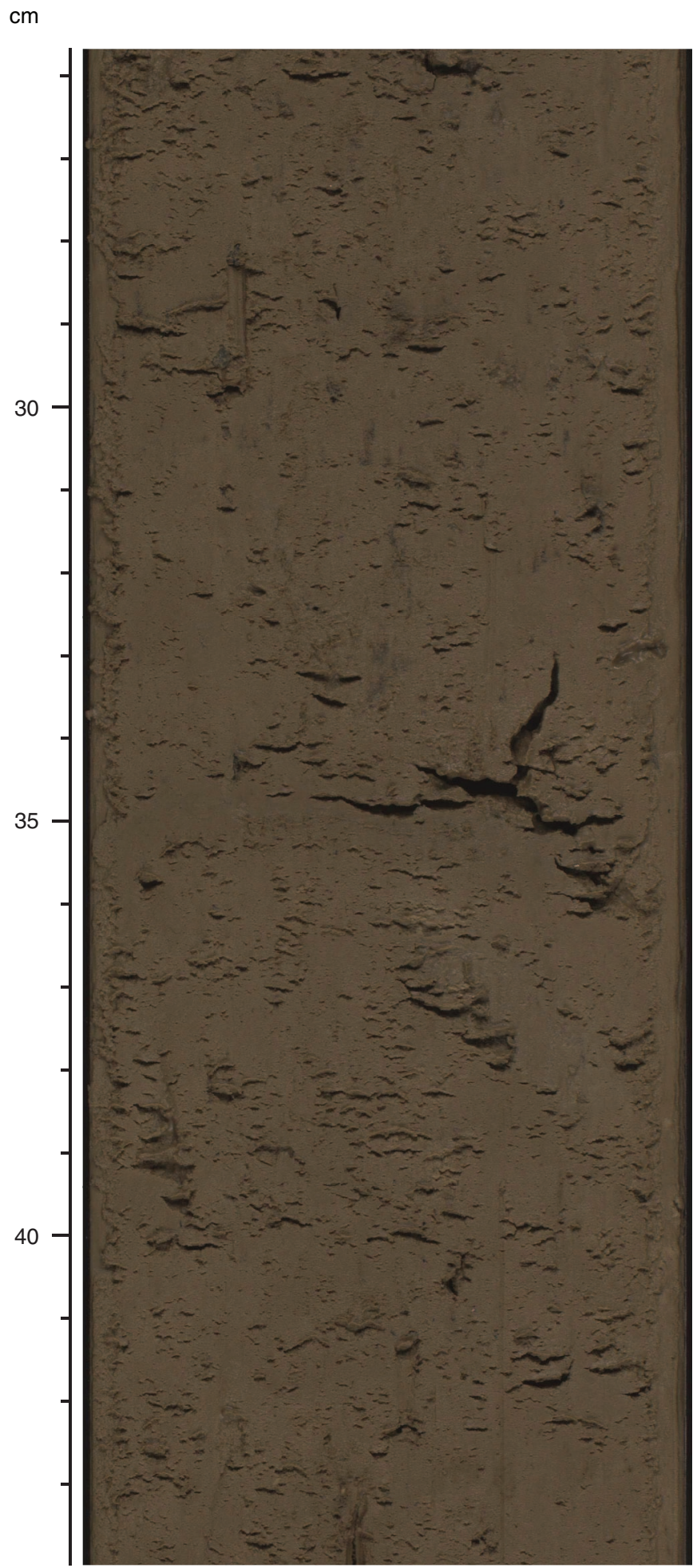


Figure F7. Core image of olive-brown foraminifer-bearing silty clay in Facies B, Hole U1361A (interval 318U1361A-2H-7, 30-59 cm).

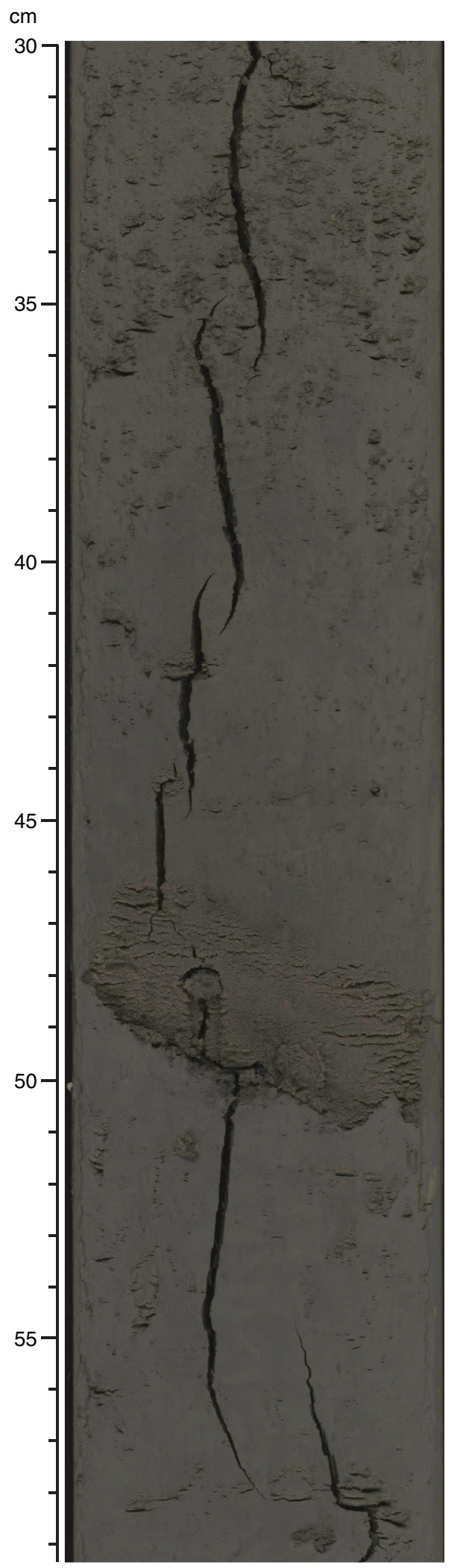


Figure F8. Core image of a set of silt and clay laminations, Hole U1361A (interval 318-U1361A-2H-6, 0-33 cm). $\mathrm{cm}$

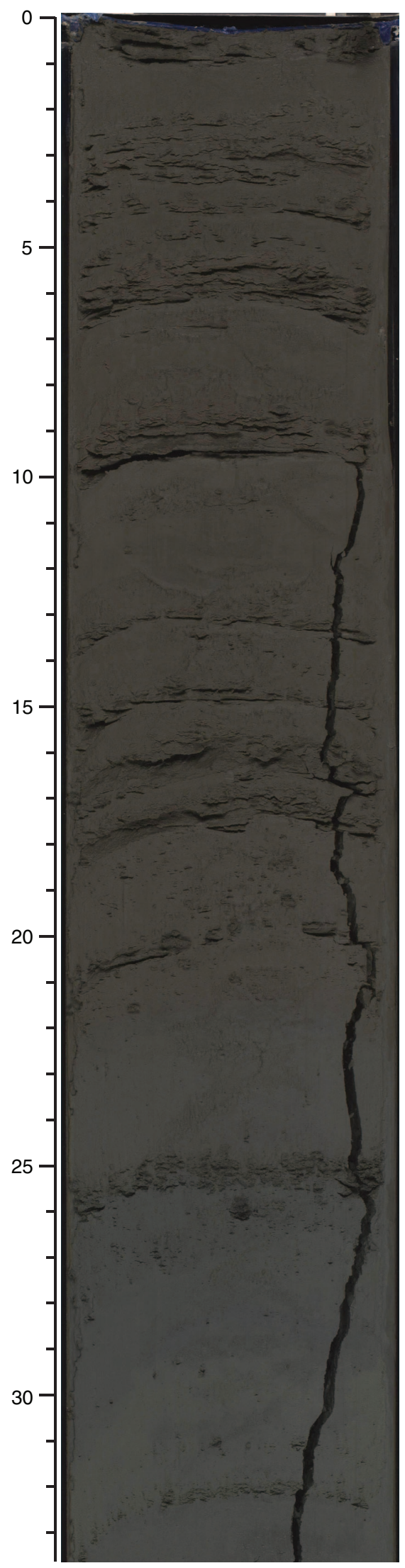


Figure F9. Core images of nannofossil ooze (Facies C), diatom-bearing silty clay (Facies D), and claystone (Facies E) in Hole U1361A. This facies succession recurs through lithostratigraphic Unit II, although the nannofossil ooze is not present in every cycle.

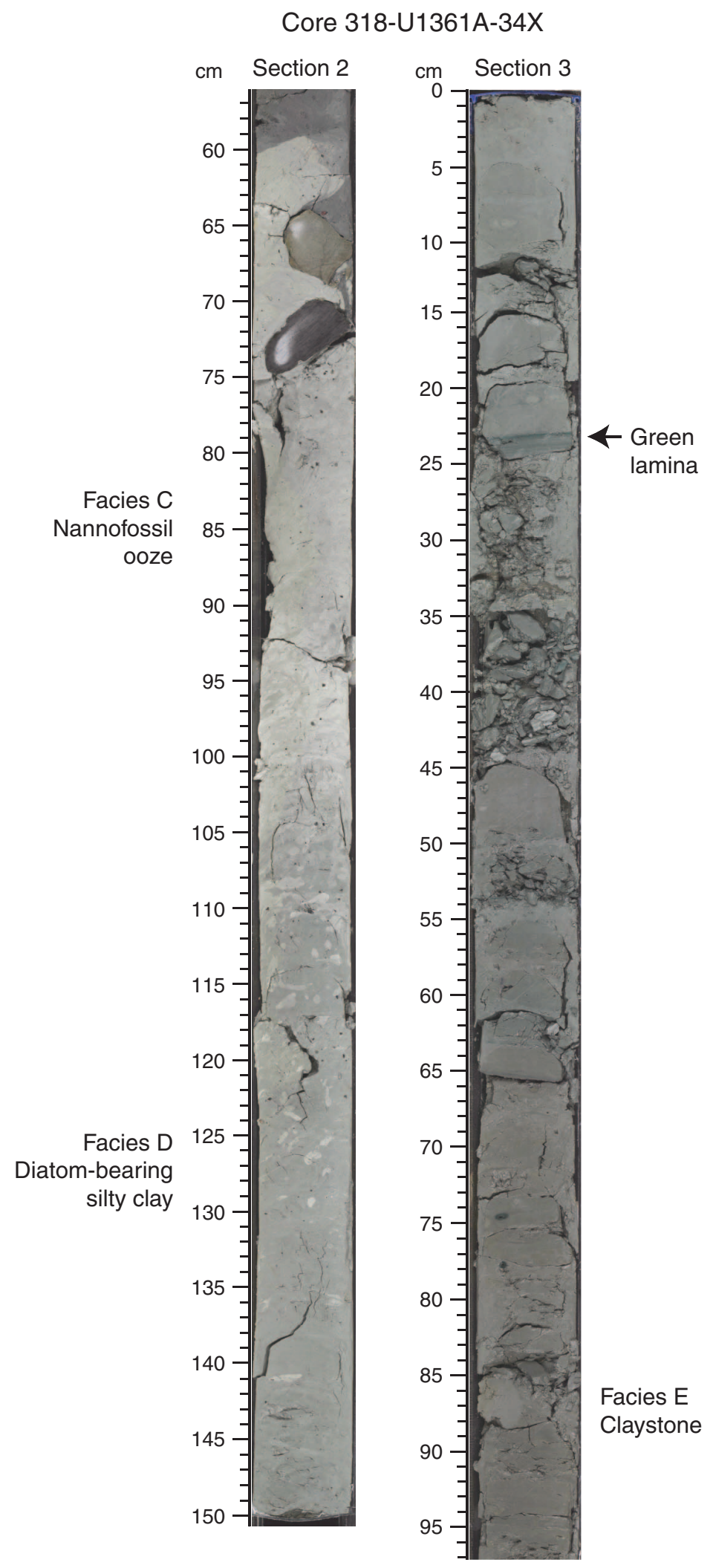


Figure F10. Plots of microfossil abundance vs. depth, Hole U1361A. Abundance: $A=$ abundant, $C=$ common, $F=$ few, $R=$ rare, $T=$ trace, $B=b a r r e n$. Preservation: $\mathrm{G}=$ good, $\mathrm{M}=$ moderate, $\mathrm{P}=$ poor. Foraminifer abundance: orange = calculated benthic, blue = benthic total. Pink shading $=$ calcareous nannofossil-rich intervals.

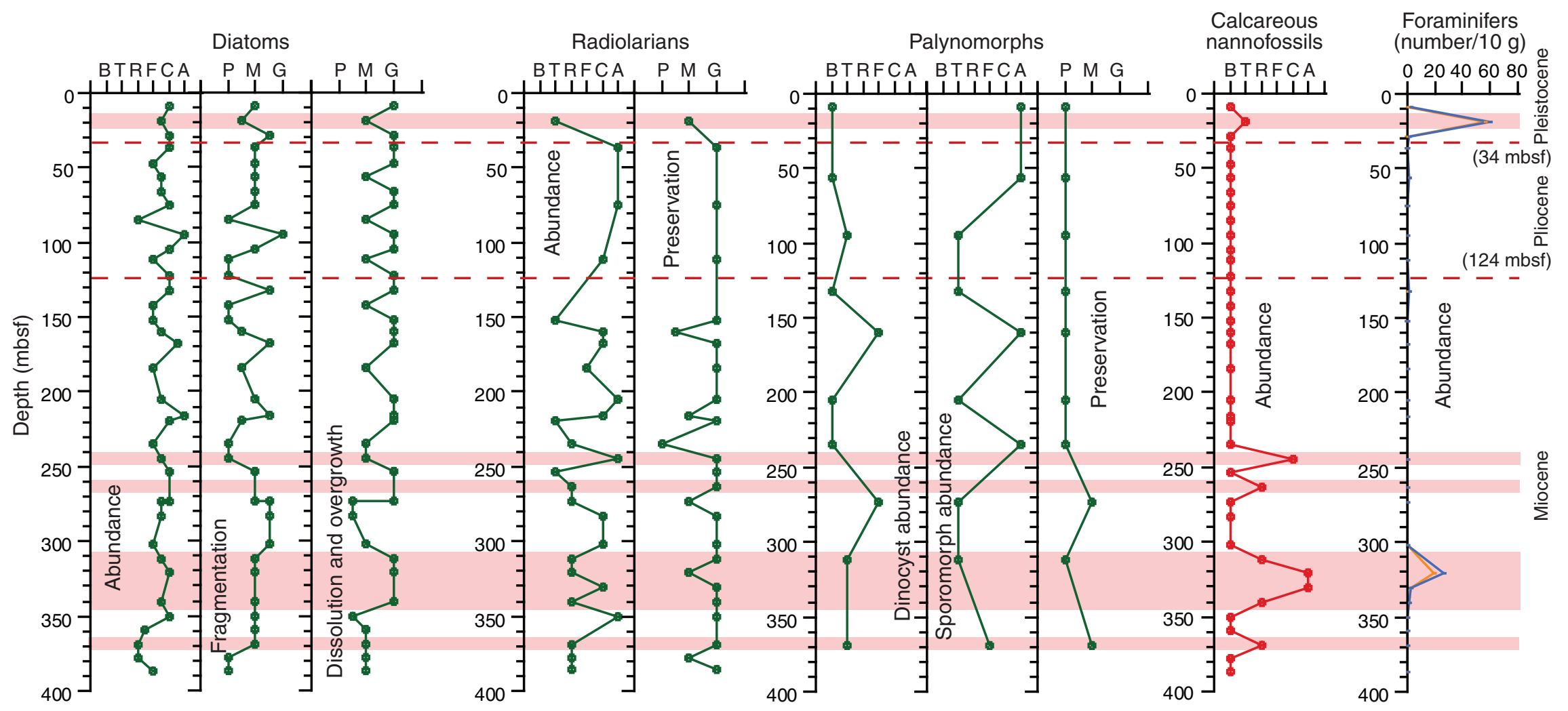


Figure F11. Plots of archive-half natural remanent magnetization. A. Hole U1361A. (Continued on next page.)

A

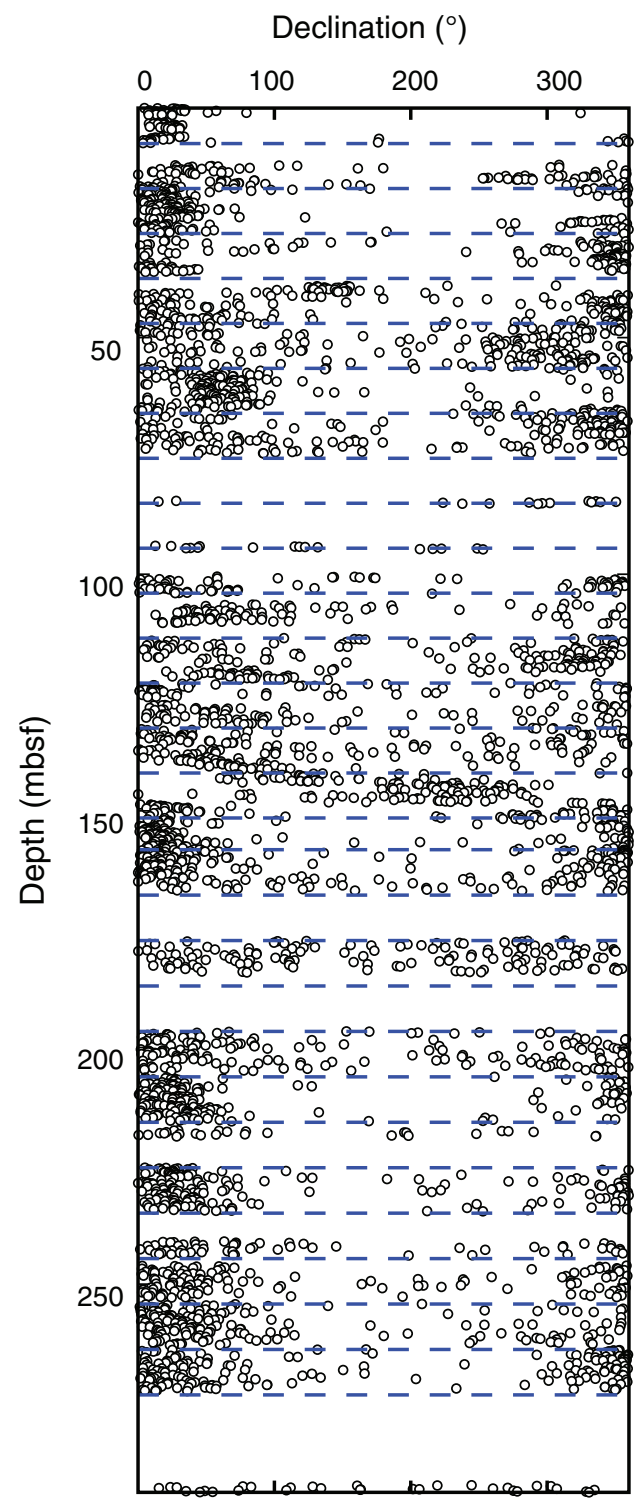

Hole U1361A

Inclination $\left({ }^{\circ}\right)$

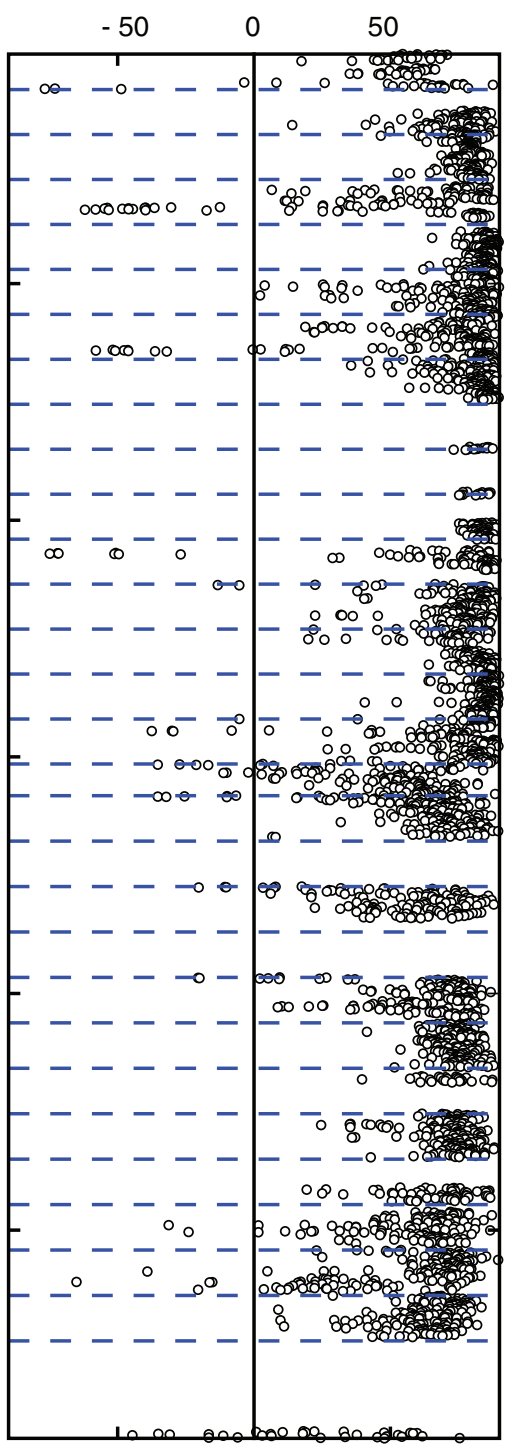

Intensity $\left(\mathrm{Am}^{2}\right)$

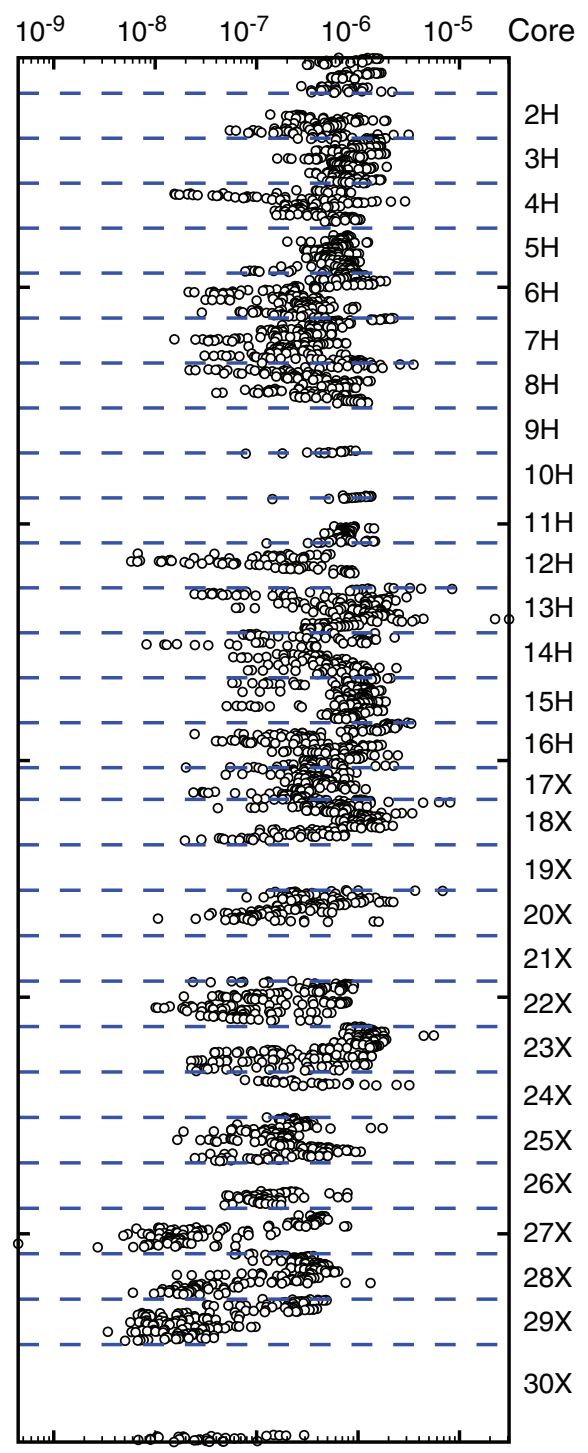


Figure F11 (continued). B. Hole U1361B.

B

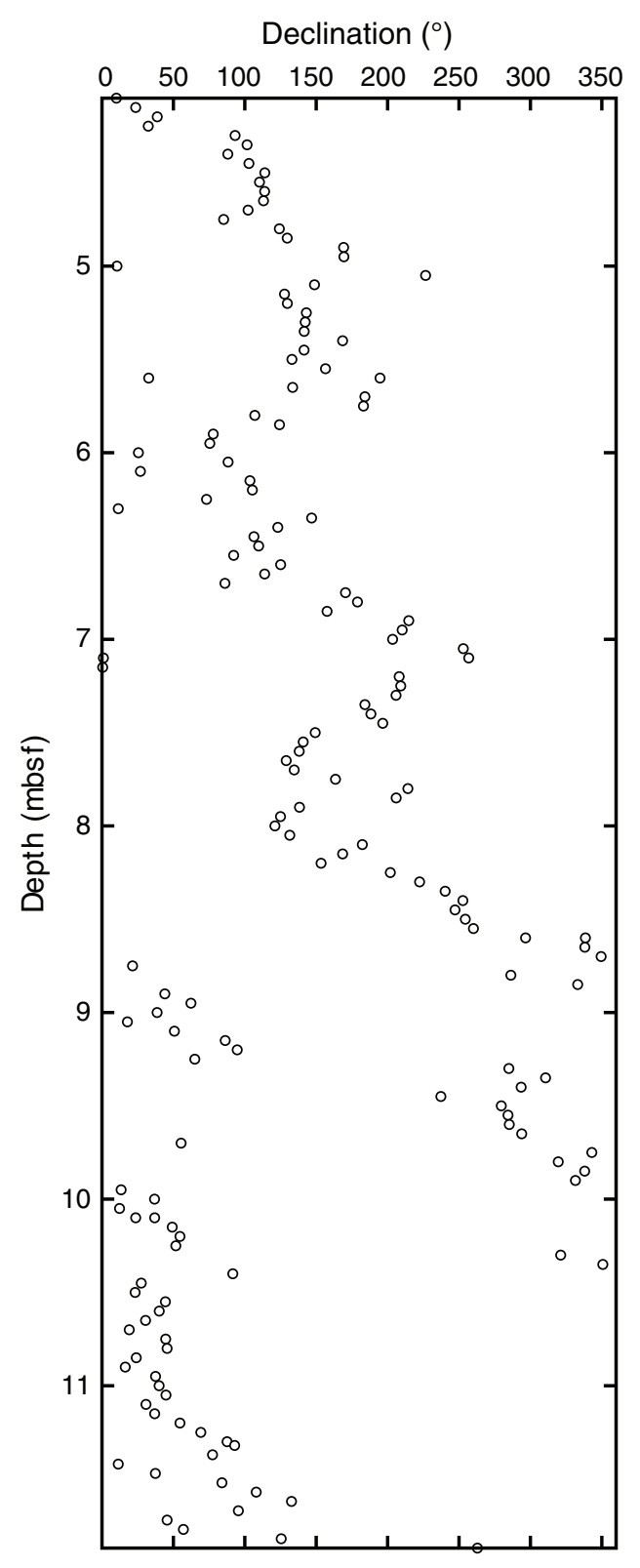

Hole U1361B

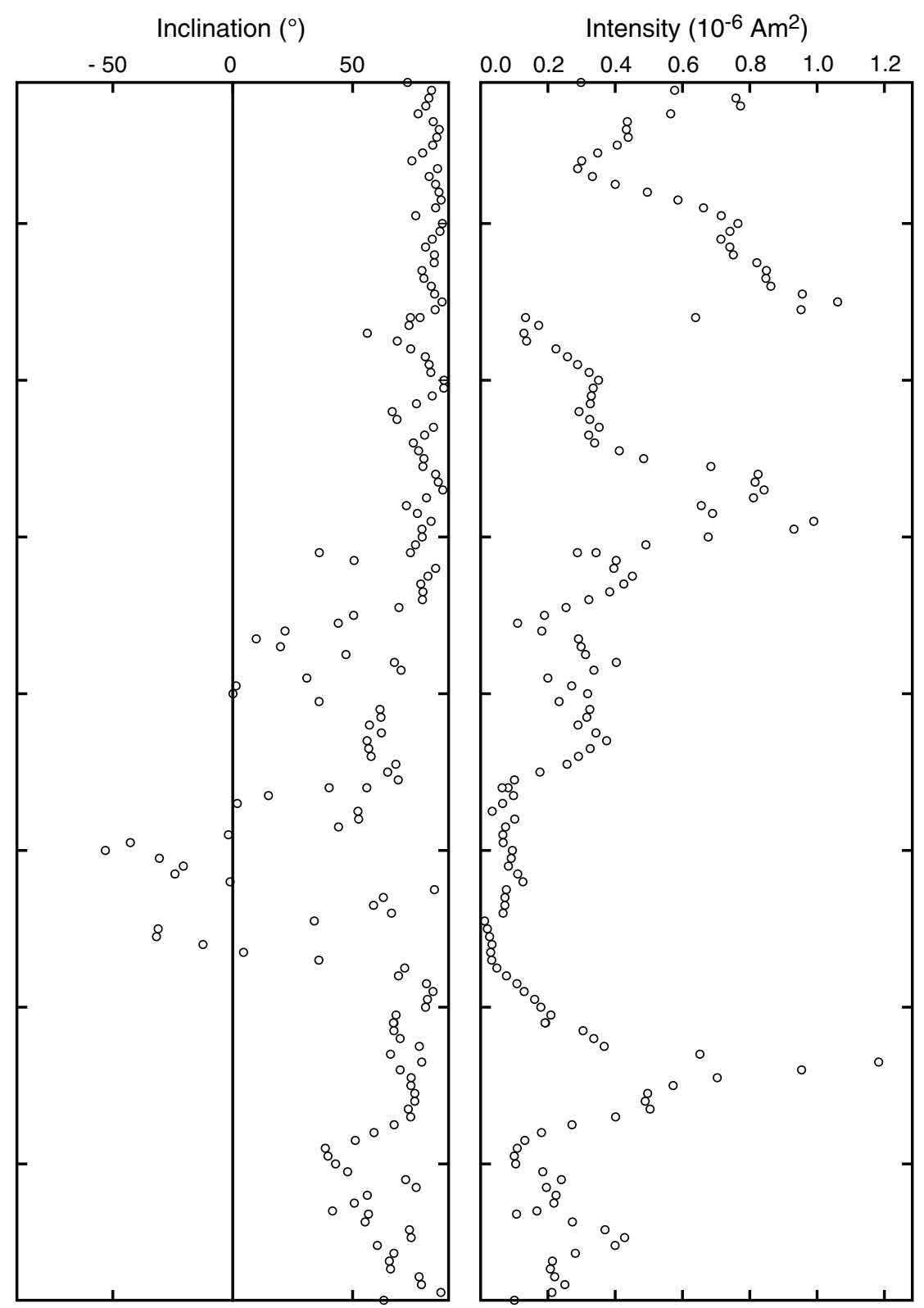


Figure F12. Plots of archive-half natural remanent magnetization (NRM). Shaded pink areas = intervals with significant gaps in recovery. A. Upper part of Hole U1361A. GPTS = geomagnetic polarity timescale (Gradstein et al., 2004), BFL = best-fit line. Dashed blue lines = core top depths. (Continued on next two pages.)

A Hole U1361A
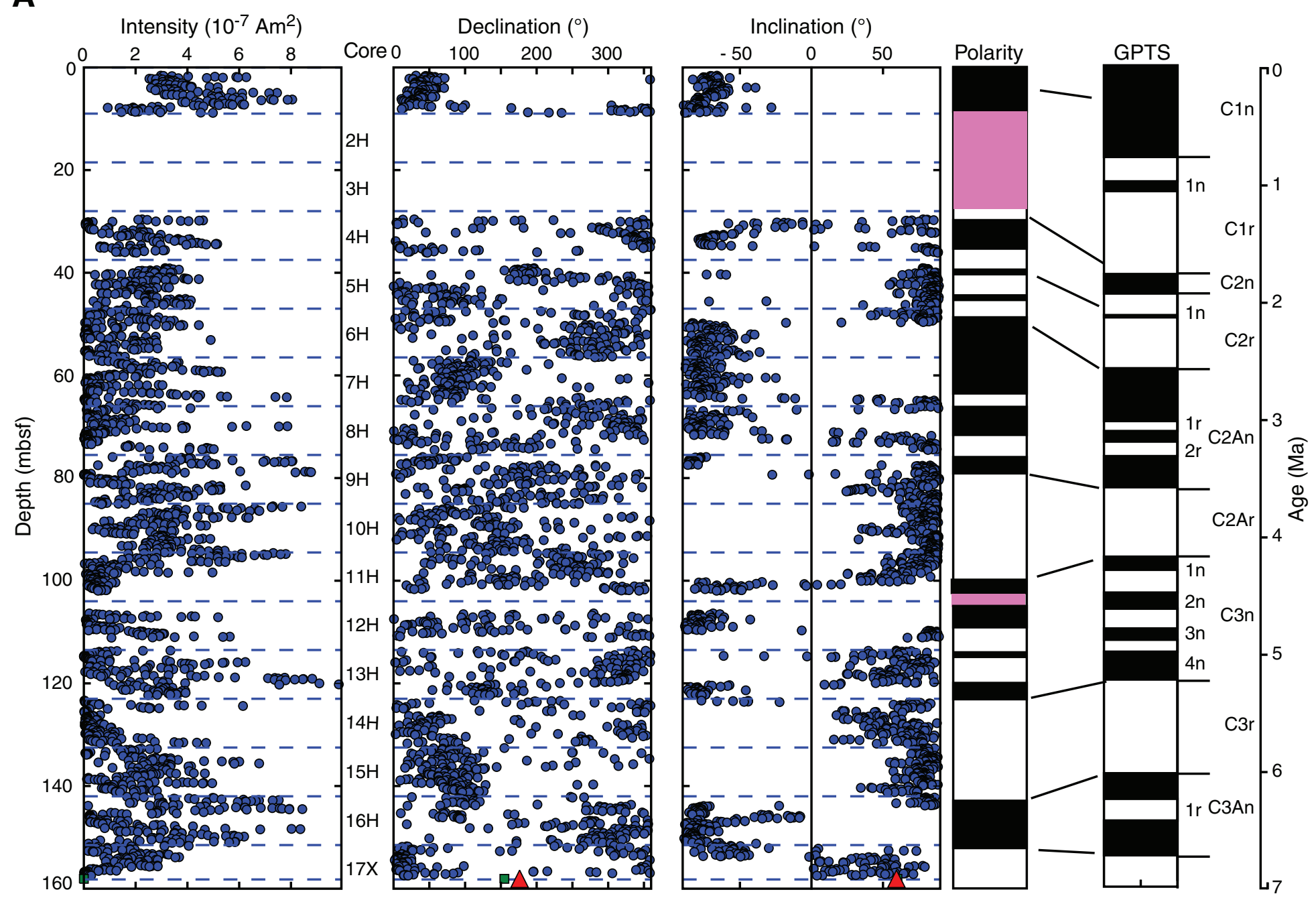

口 NRM (20 mT)

- NRM (20 mT, edited)

$\triangle \mathrm{BFL}$ 
Figure F12 (continued). B. Lower part of Hole U1361A. GPTS = geomagnetic polarity timescale (Gradstein et al., 2004), BFL = best-fit line. Dashed blue lines = core top depths. (Continued on next page.)

B

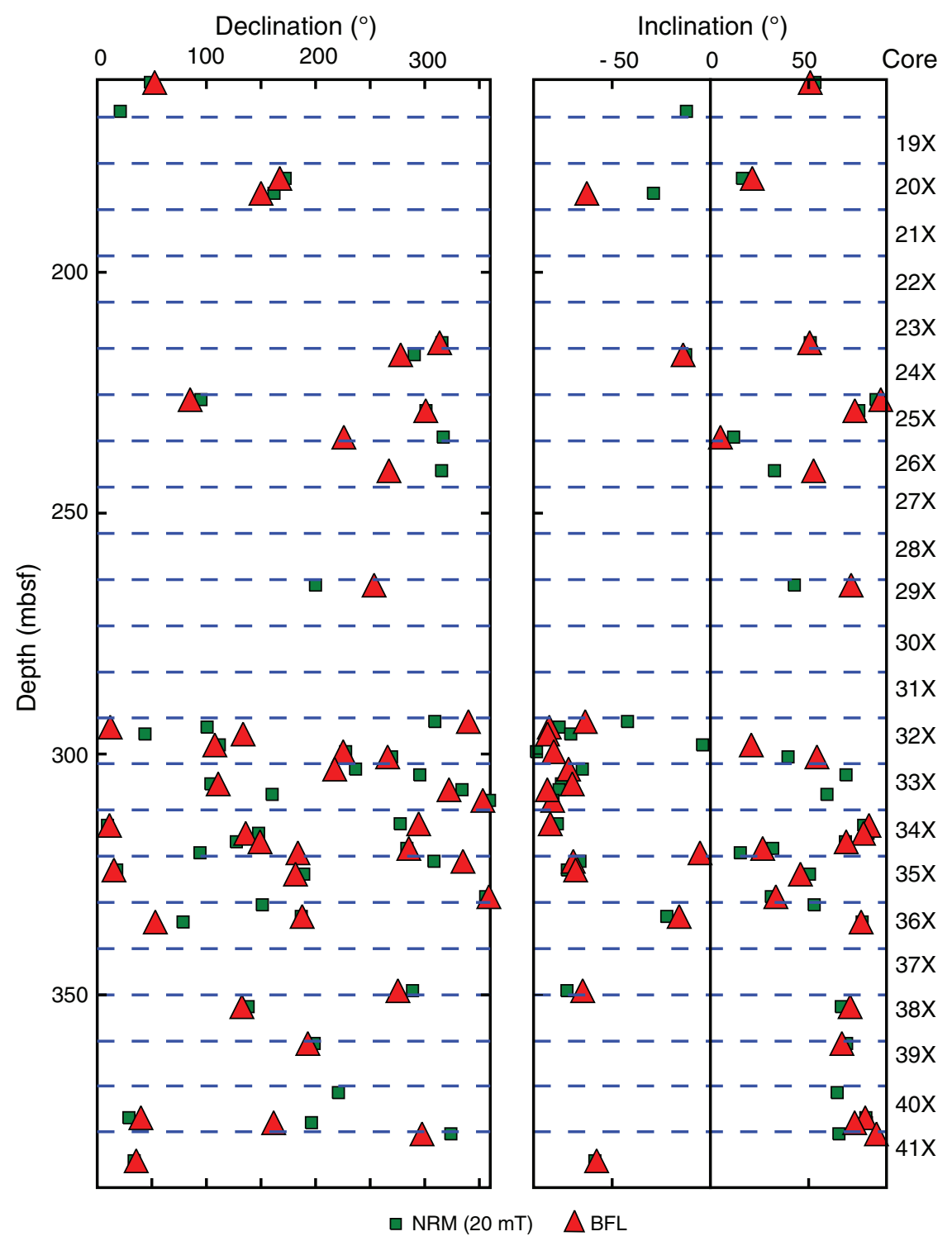

Hole U1361A

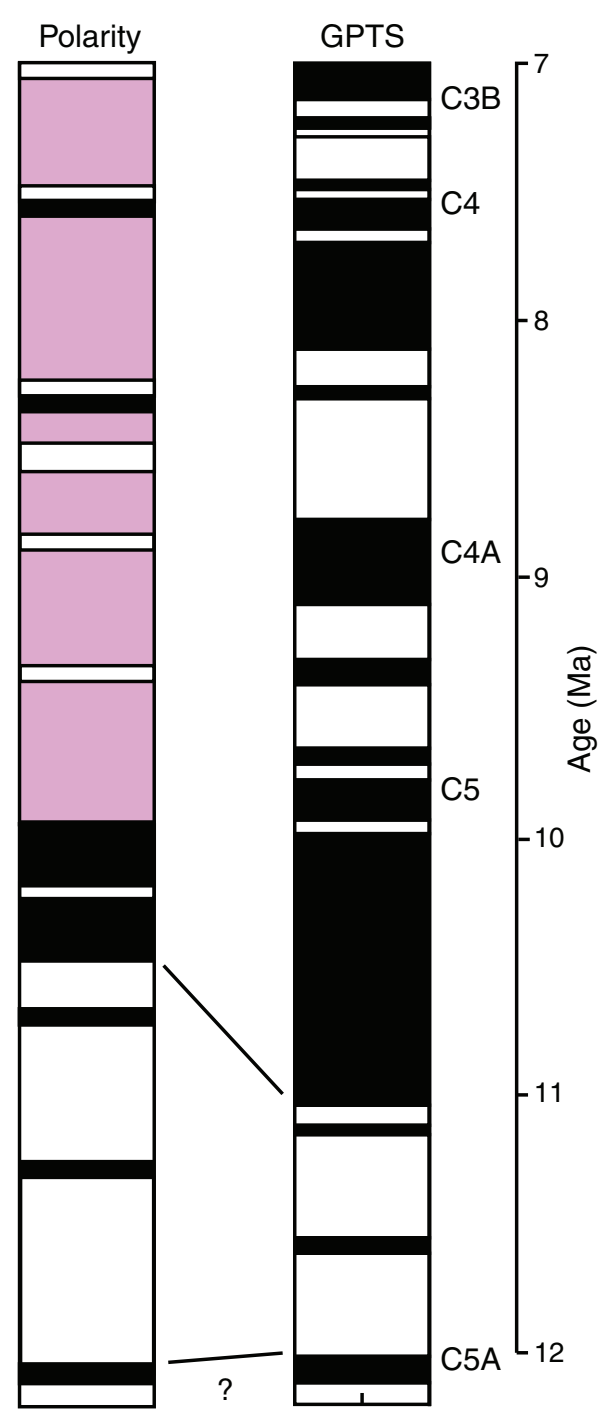


Figure F12 (continued). C. Hole U1361B.

Hole U1361B
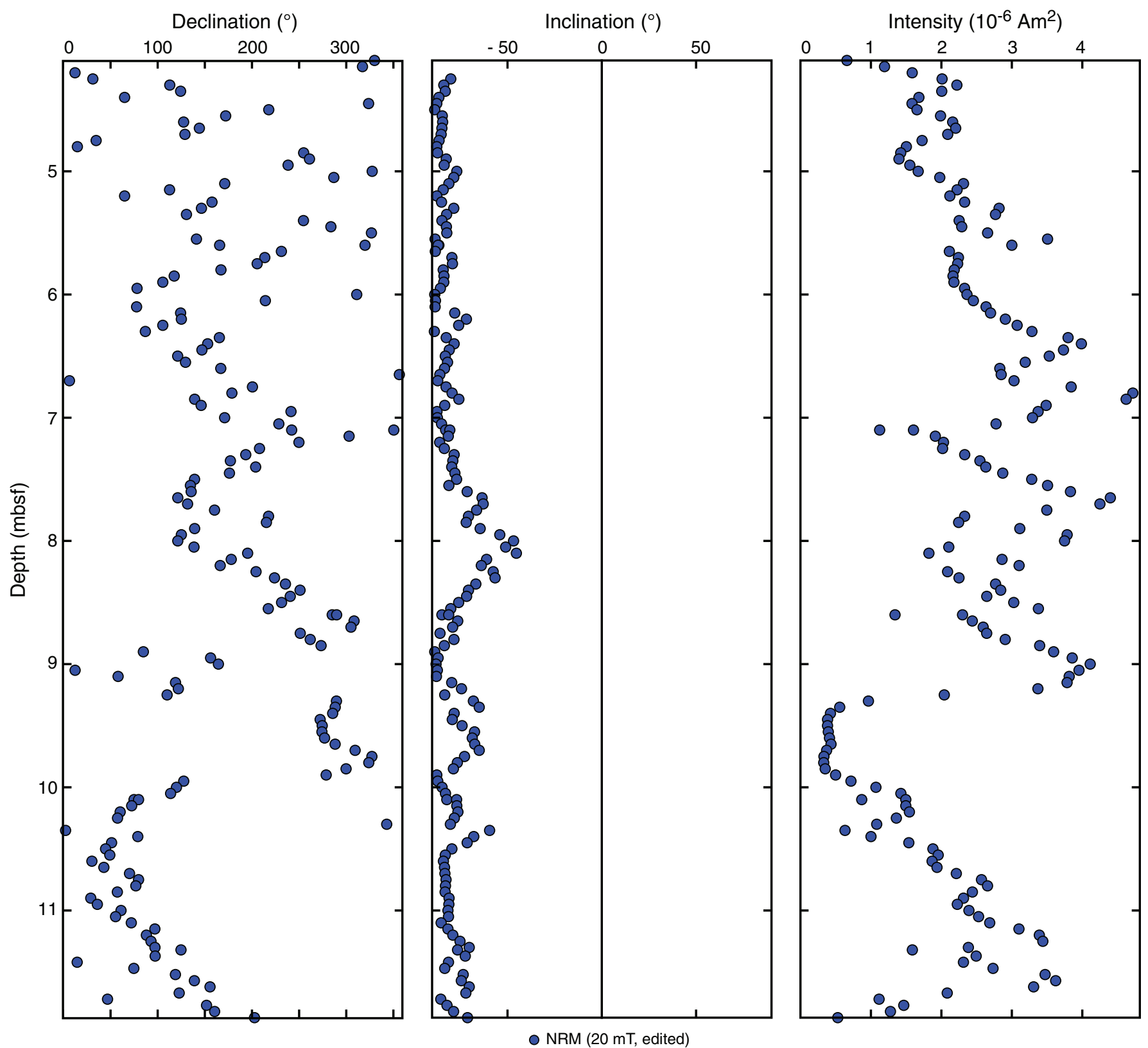
Figure F13. Plots of anisotropy of magnetic susceptibility vs. depth. A. Eigenvalues. B. Inclination of $\mathrm{V}_{3}$ eigenvector. C. Bulk susceptibility.

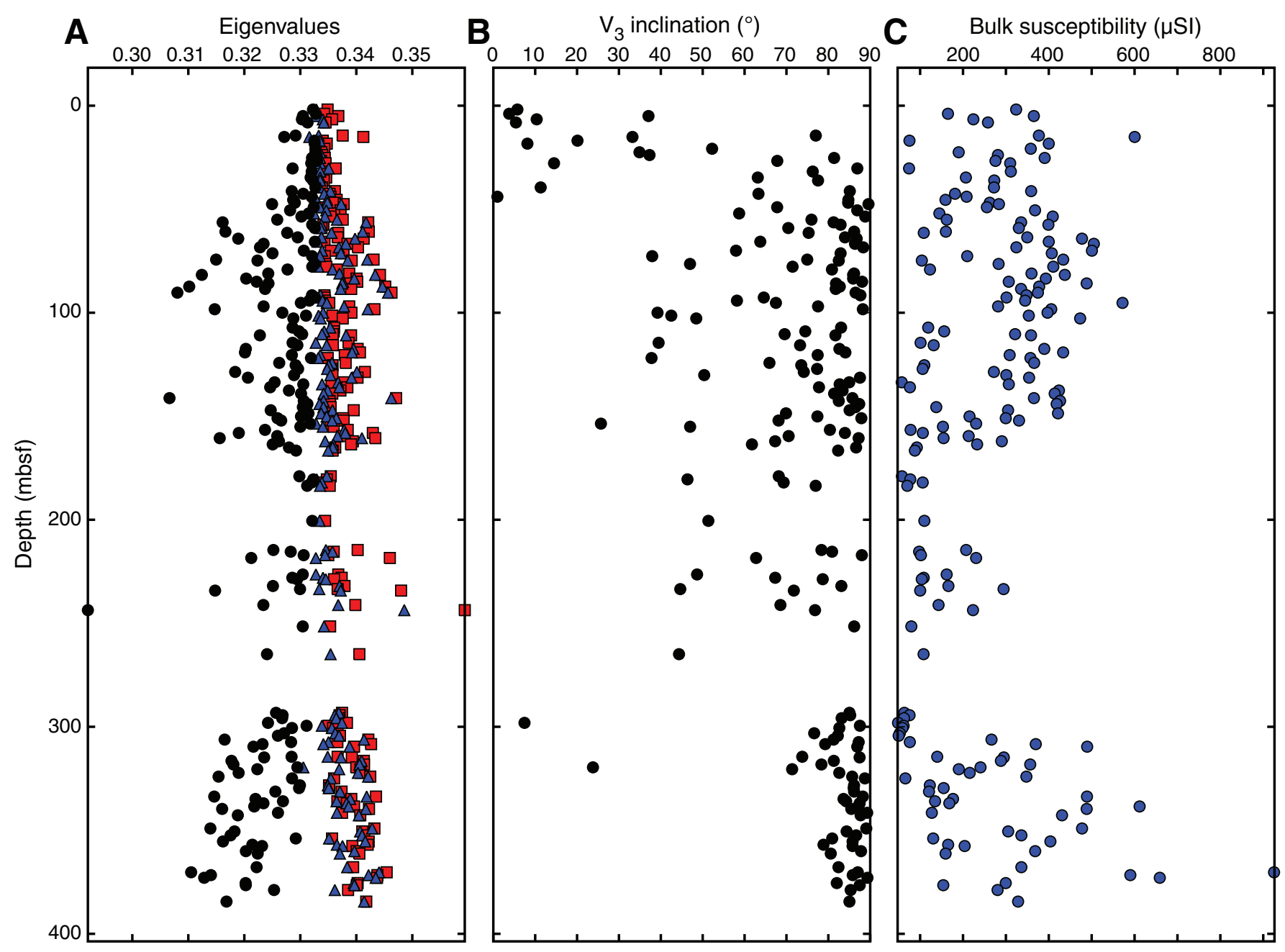


Figure F14. Plots of (A) methane concentrations and (B) methane/ethane ratios, Hole U1361A.

A

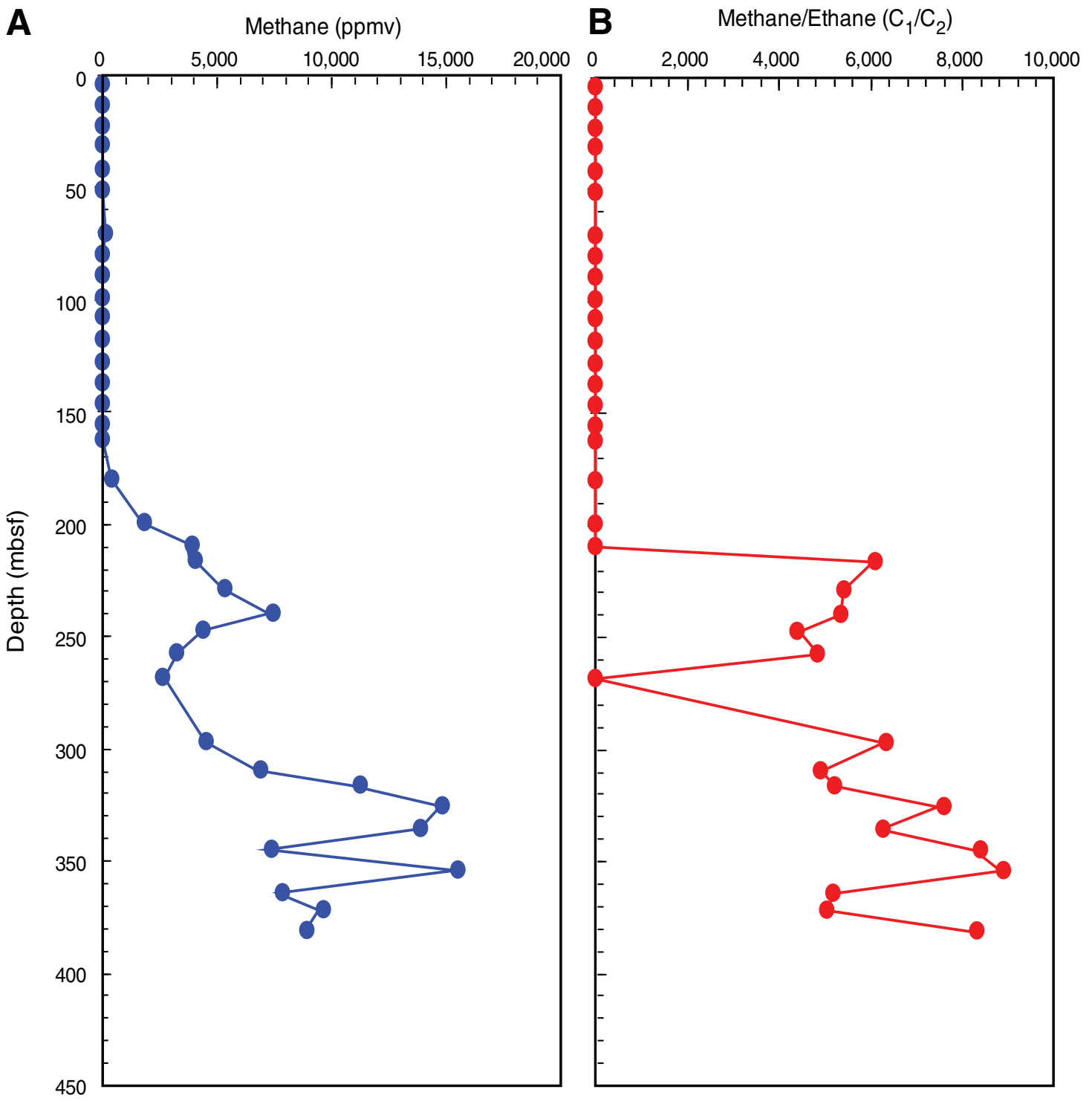


Figure F15. Plot of calcium carbonate data, Hole U1361A.

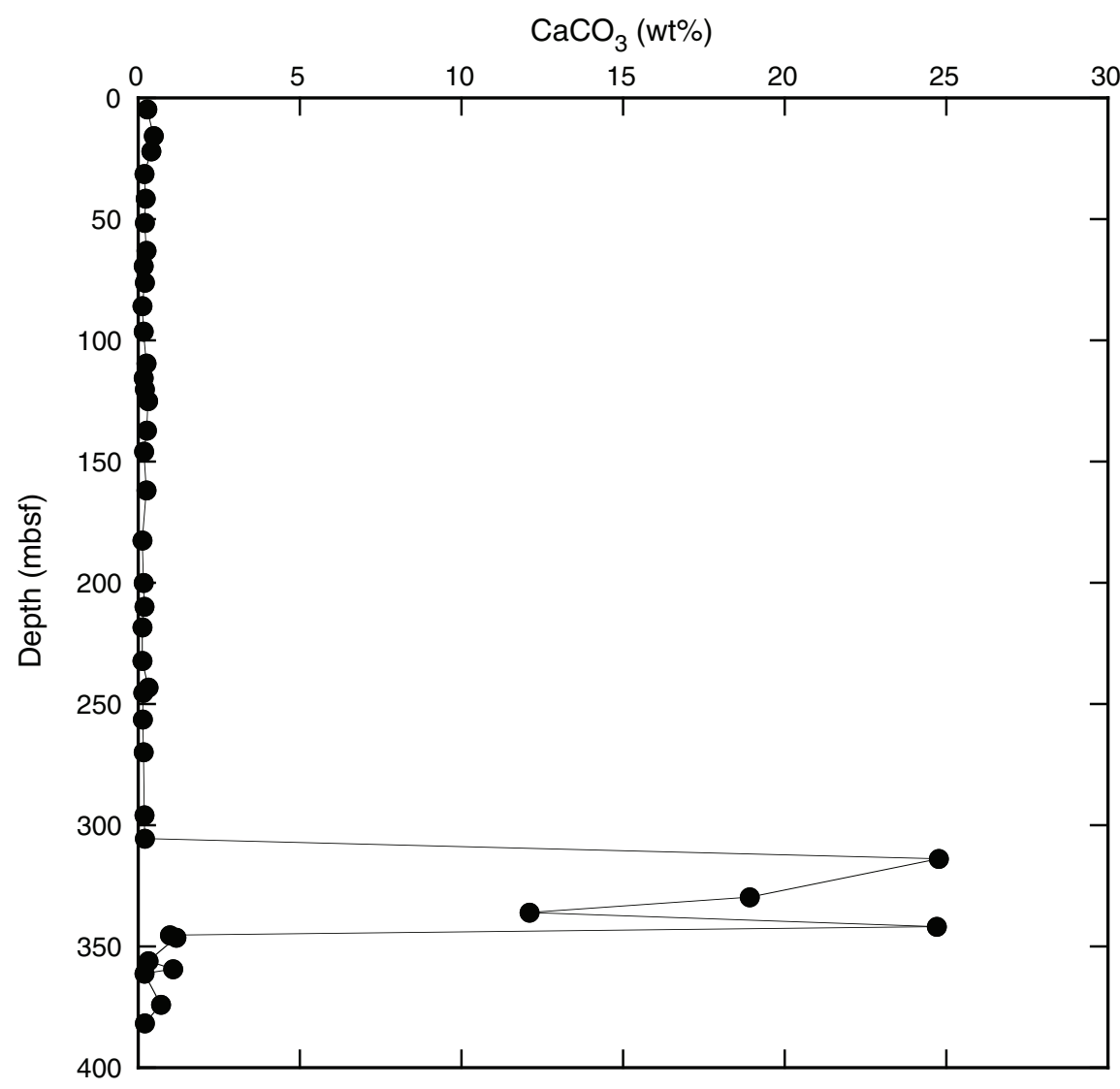


Figure F16. Plots of total carbon, nitrogen, and sulfur contents, Hole U1361A.

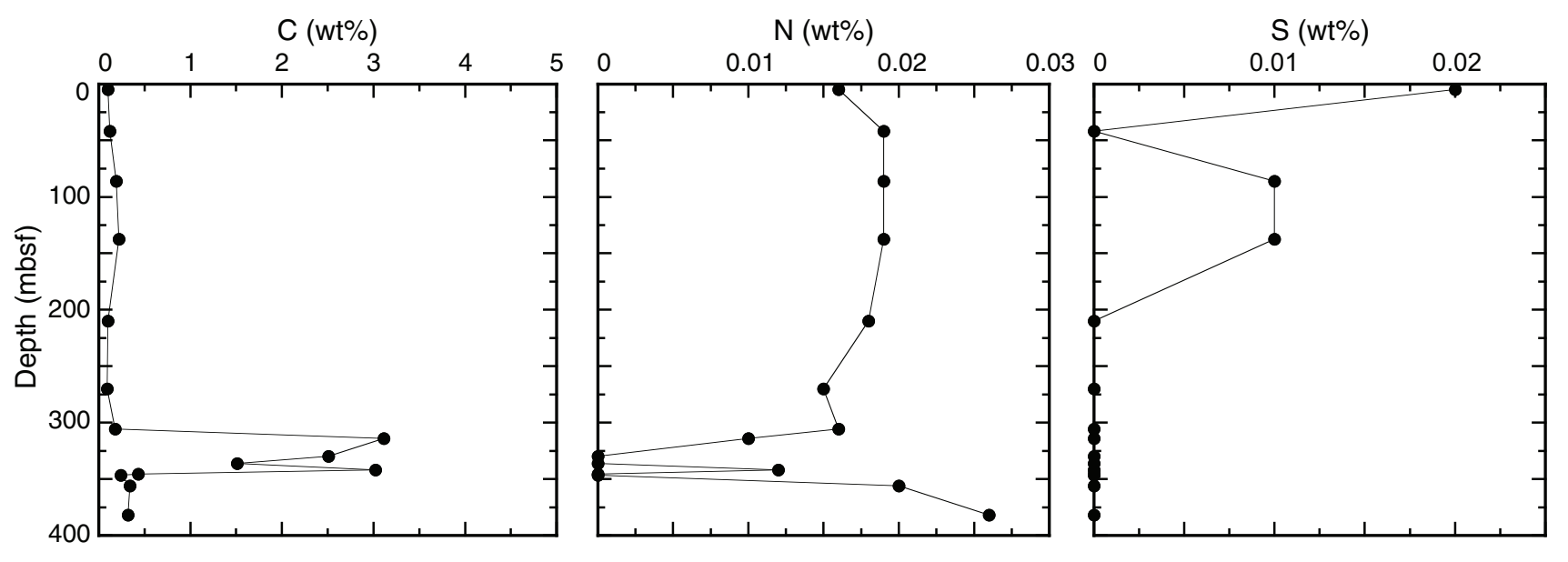


Figure F17. Plots of magnetic susceptibility and natural gamma radiation (NGR) measurements, Site U1361. Black squares $=$ Hole U1361A, red circles $=$ Hole U1361B.

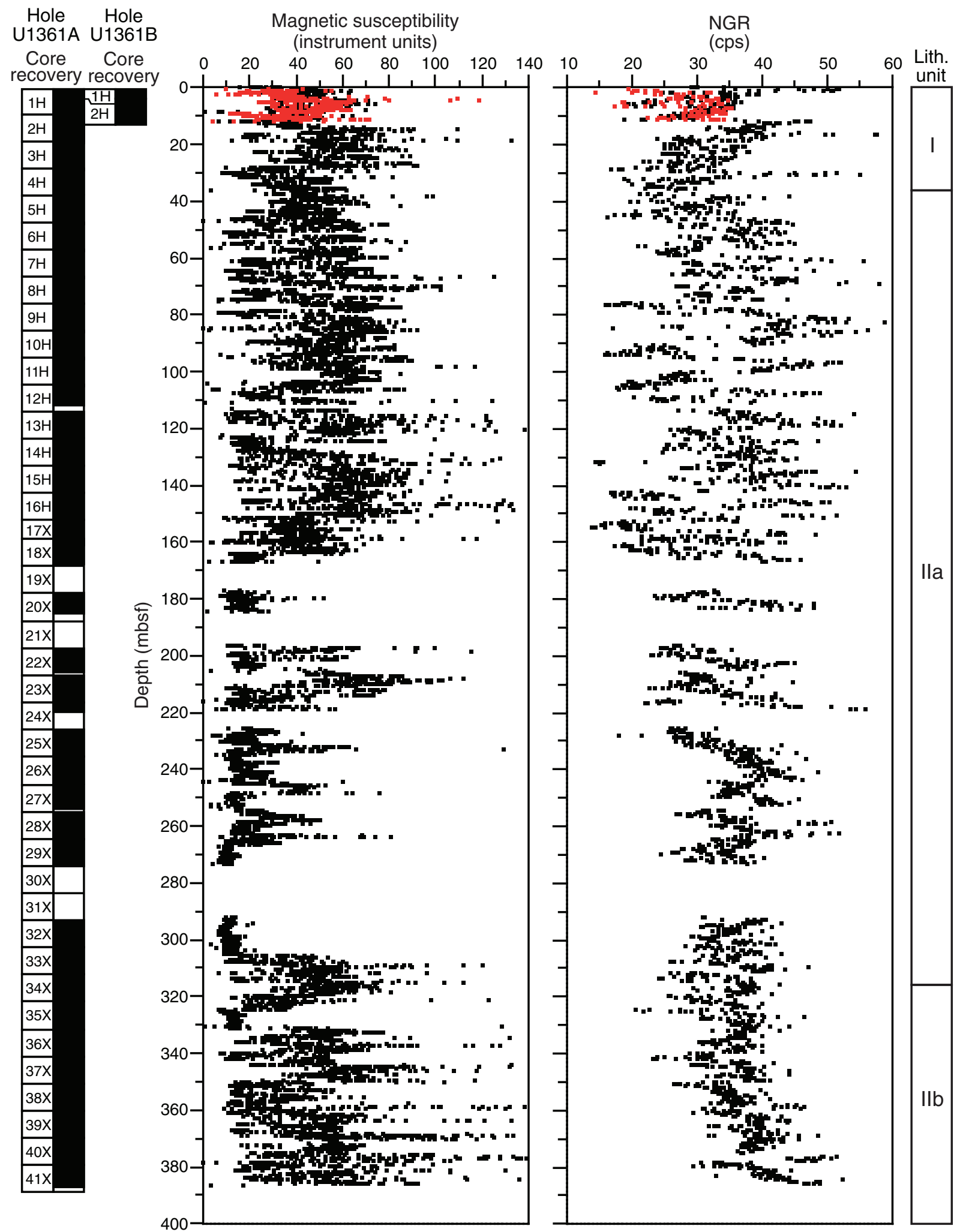


Figure F18. Plot of GRA density measurements (gray squares $=$ Hole U1361A, blue squares $=$ Hole U1361B) and discrete density measurements in Hole U1361A (red circles).

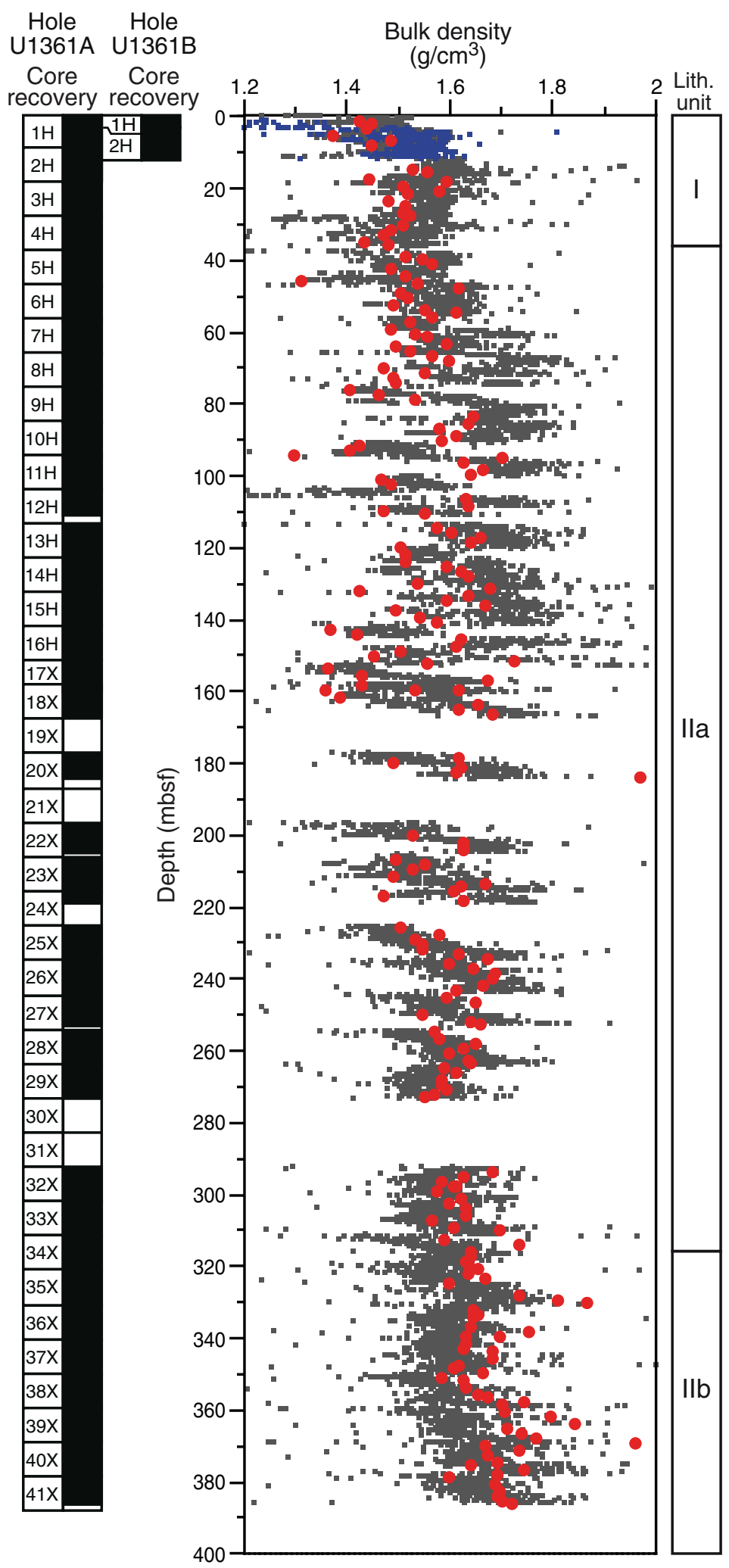


Figure F19. Plot of $P$-wave logger (PWL), $P$-wave caliper ( $x$-axis), and $P$-wave bayonet $(y$-and $z$-axes) velocity measurements, Hole U1361A.

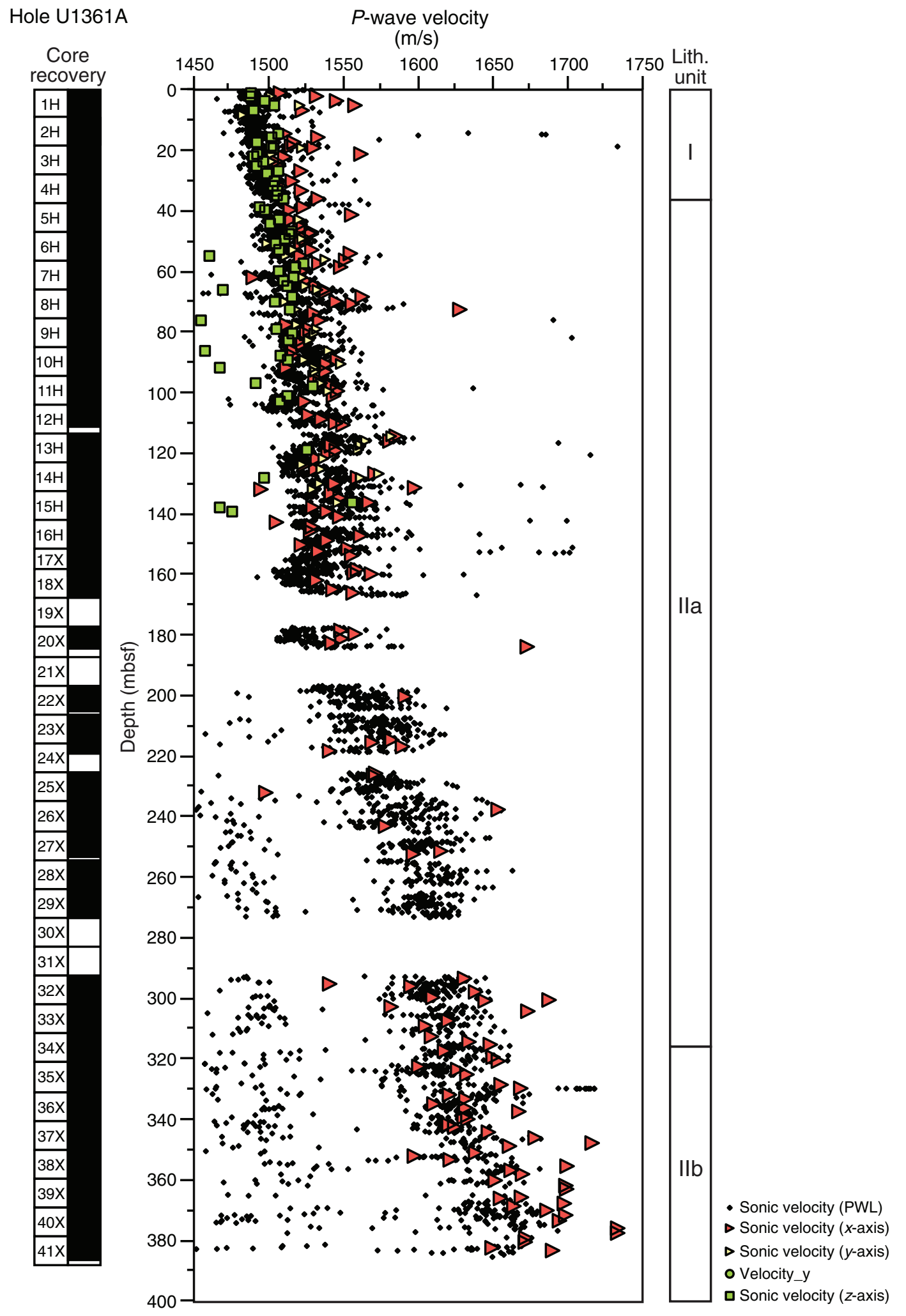


Figure F20. Plot of discrete $P$-wave velocity measurements, Hole U1361A.

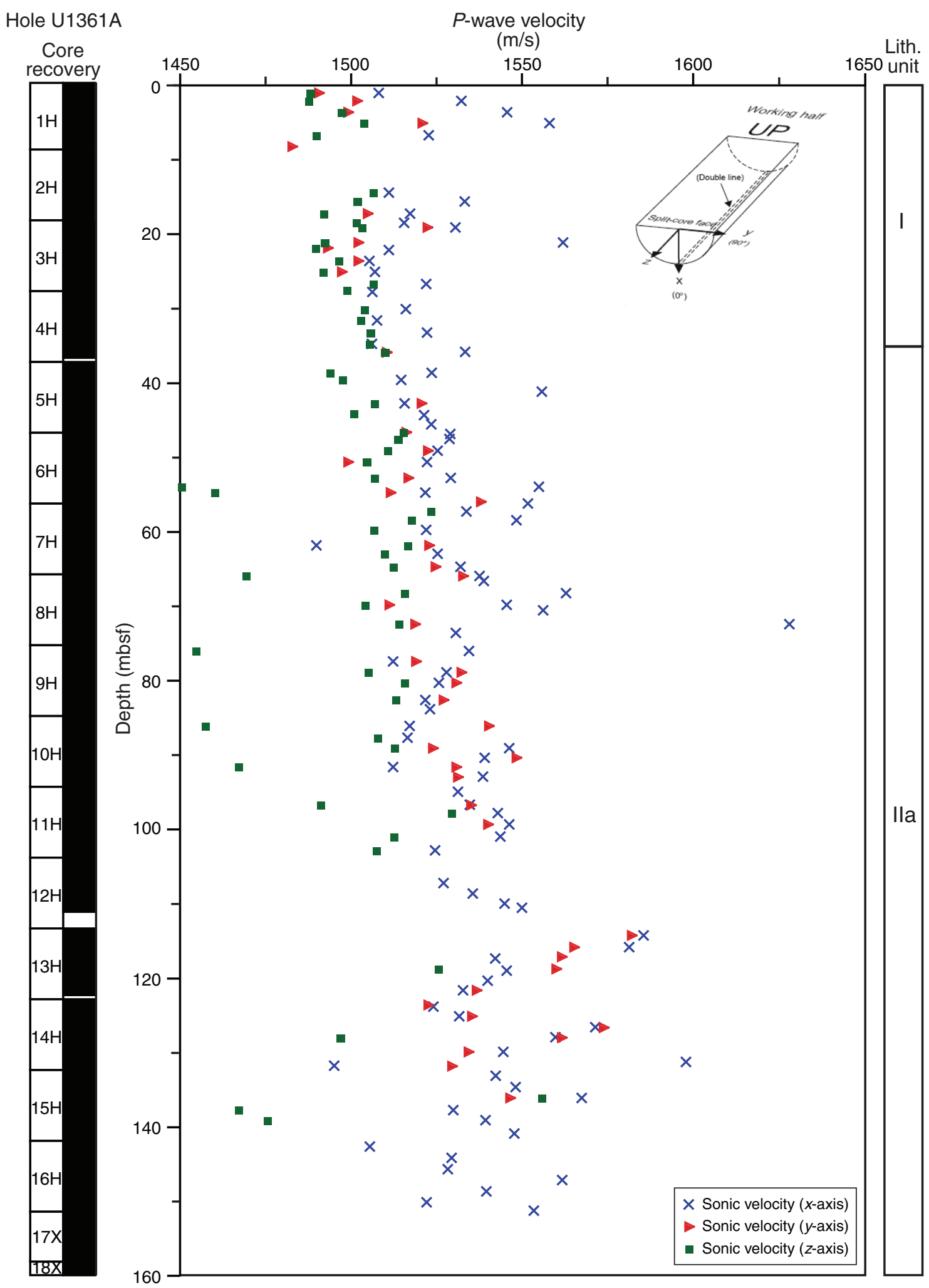


Figure F21. Discrete $P$-wave velocity plots (uppermost 160 mbsf), Hole U1361A. For further explanation, see text.
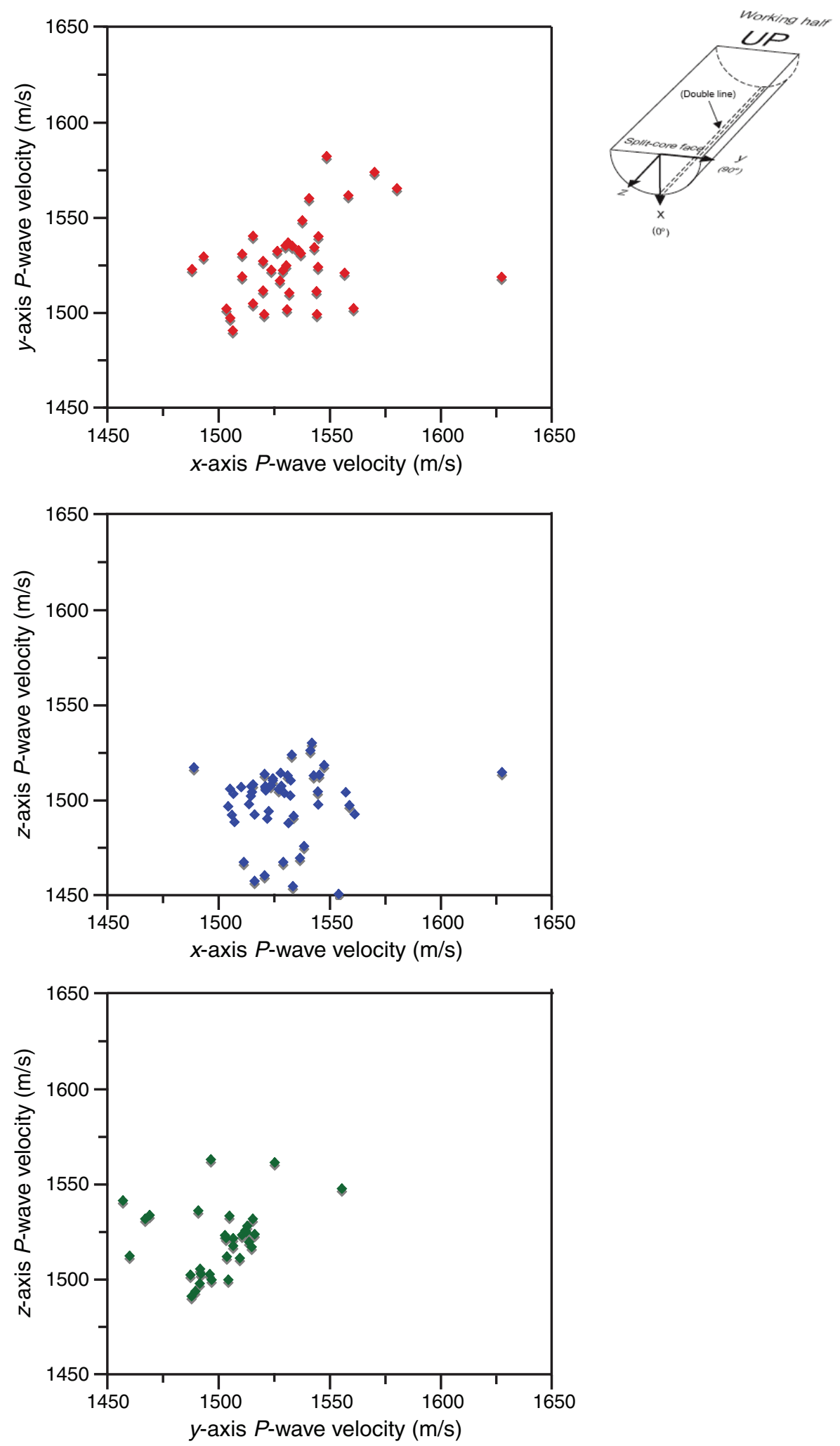
Figure F22. Plots of grain density and porosity, Hole U1361A.

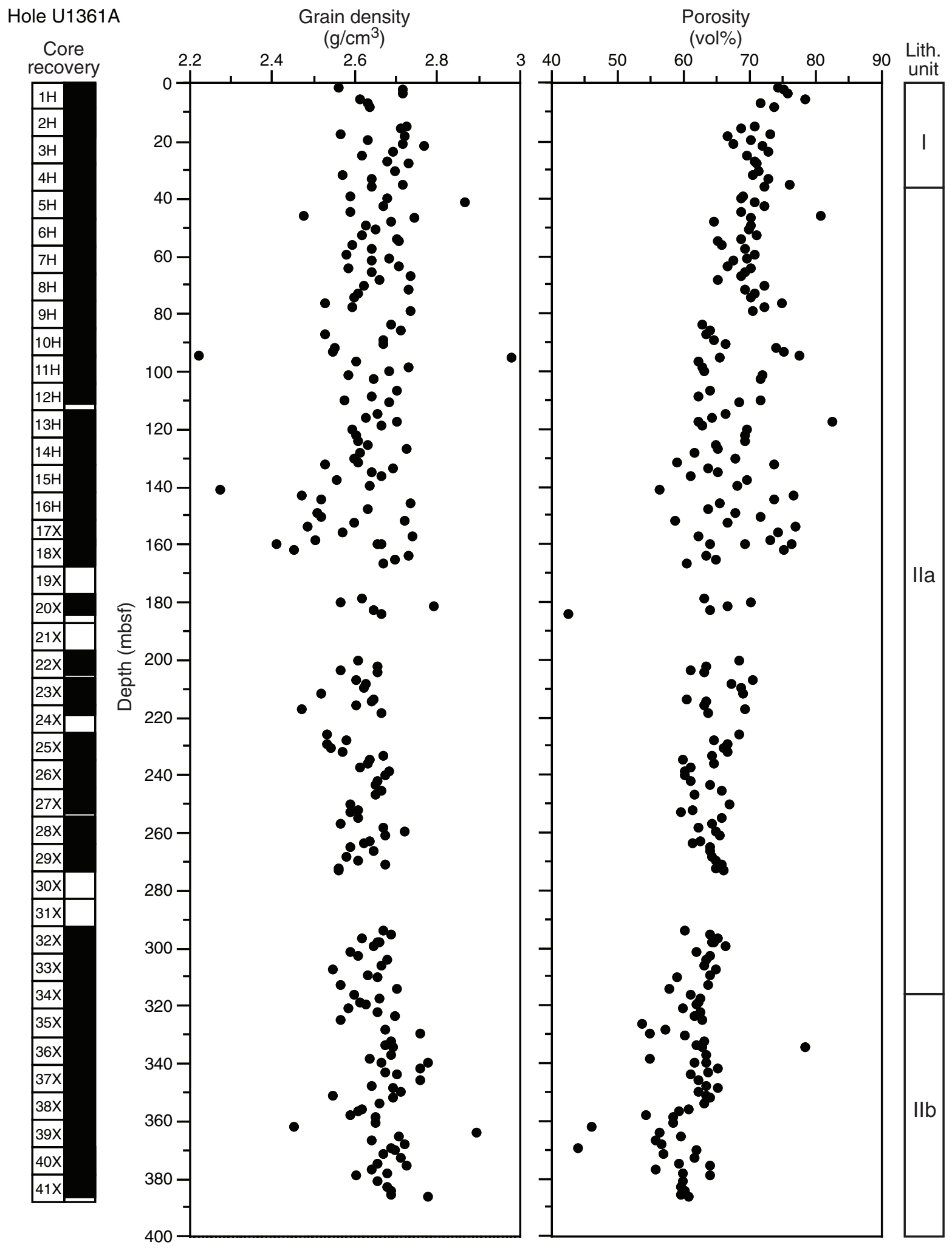


Figure F23. Plots of wet bulk and dry density, Hole U1361A.

Hole U1361A

Core

recovery

\begin{tabular}{|l|}
\hline $1 \mathrm{H}$ \\
\hline $2 \mathrm{H}$ \\
\hline $3 \mathrm{H}$ \\
\hline $4 \mathrm{H}$ \\
\hline $5 \mathrm{H}$ \\
\hline $6 \mathrm{H}$ \\
\hline $7 \mathrm{H}$ \\
\hline $8 \mathrm{H}$ \\
\hline $9 \mathrm{H}$ \\
\hline $10 \mathrm{H}$ \\
\hline $11 \mathrm{H}$ \\
\hline $12 \mathrm{H}$ \\
\hline $13 \mathrm{H}$ \\
\hline $14 \mathrm{H}$ \\
\hline $15 \mathrm{H}$ \\
\hline $16 \mathrm{H}$ \\
\hline $17 \mathrm{X}$ \\
\hline $18 \mathrm{X}$ \\
\hline $19 \mathrm{X}$ \\
\hline $20 \mathrm{X}$ \\
\hline $21 \mathrm{X}$ \\
\hline $22 \mathrm{X}$ \\
\hline $23 \mathrm{X}$ \\
\hline $24 \mathrm{X}$ \\
\hline $25 \mathrm{X}$ \\
\hline $26 \mathrm{X}$ \\
\hline $27 \mathrm{X}$ \\
\hline $28 \mathrm{X}$ \\
\hline $29 \mathrm{X}$ \\
\hline $30 \mathrm{X}$ \\
\hline $31 \mathrm{X}$ \\
\hline $32 \mathrm{X}$ \\
\hline $33 \mathrm{X}$ \\
\hline $34 \mathrm{X}$ \\
\hline $35 \mathrm{X}$ \\
\hline $36 \mathrm{X}$ \\
\hline $37 \mathrm{X}$ \\
\hline $38 \mathrm{X}$ \\
\hline $39 \mathrm{X}$ \\
\hline $40 \mathrm{X}$ \\
\hline $41 \mathrm{X}$ \\
\hline
\end{tabular}
Wet bulk density

$\left(\mathrm{g} / \mathrm{cm}^{3}\right)$

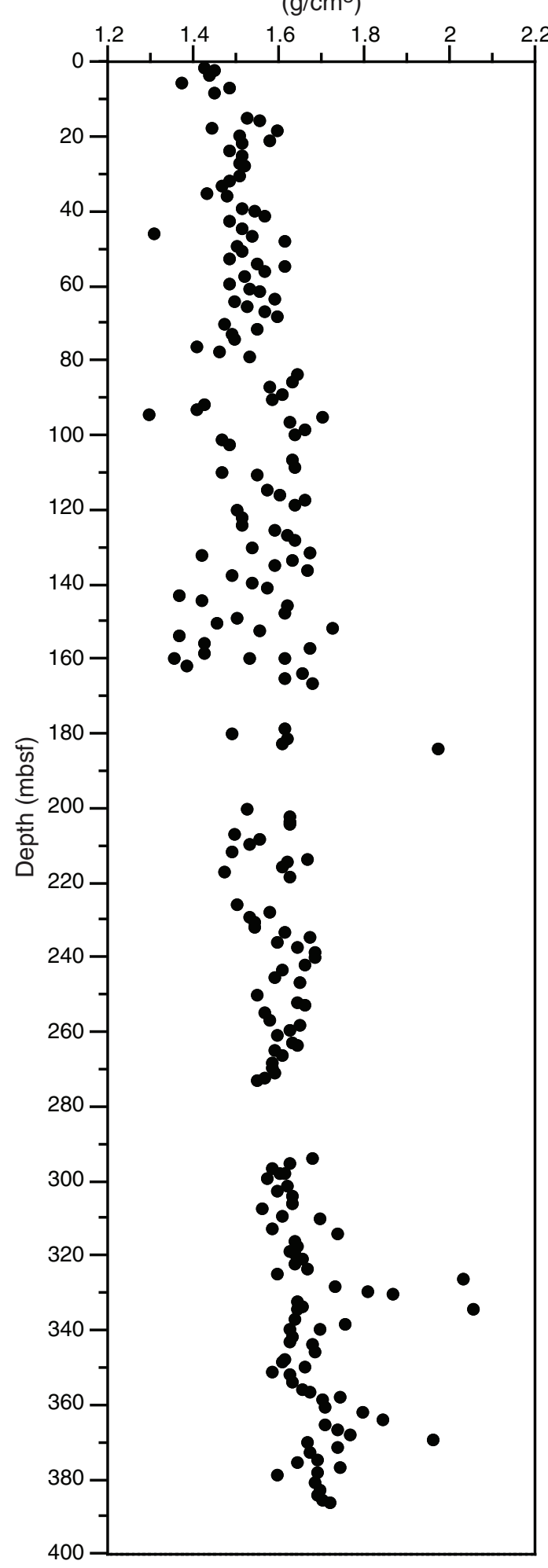

Dry density

$\left(\mathrm{g} / \mathrm{cm}^{3}\right)$

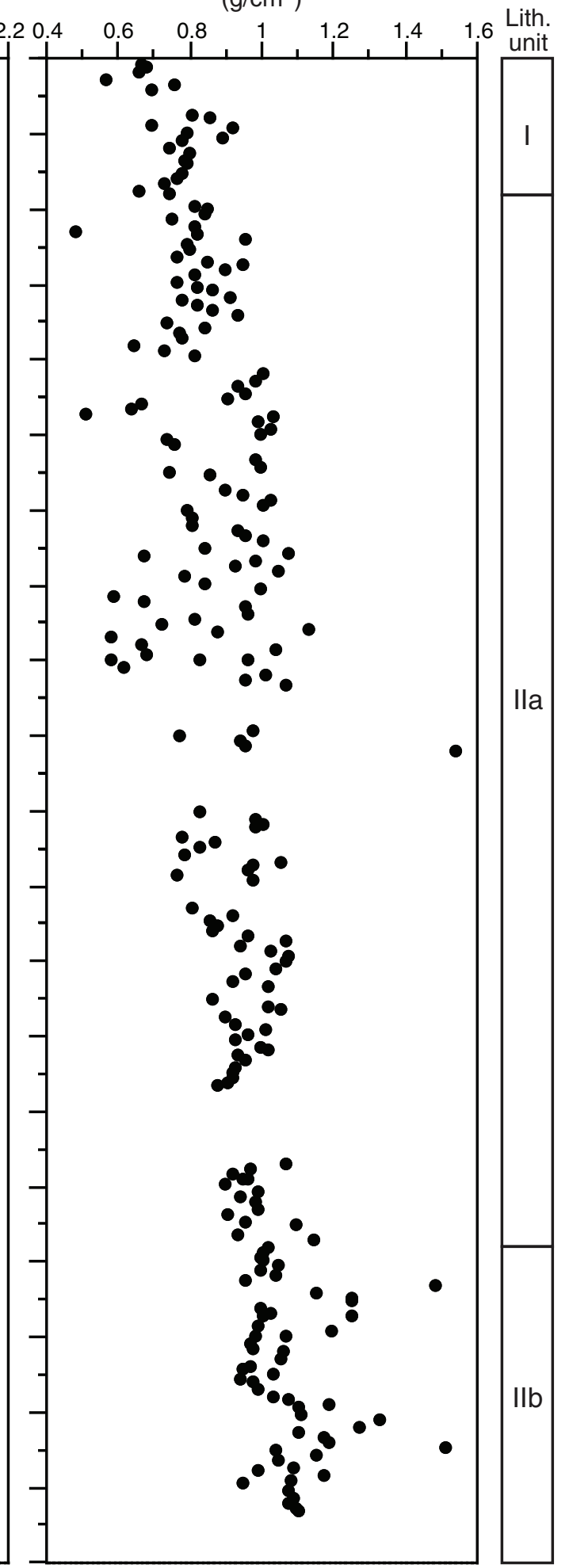


Figure F24. Plots of relative moisture content and void ratio, Hole U1361A.

Hole U1361A

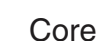

Core
recovery

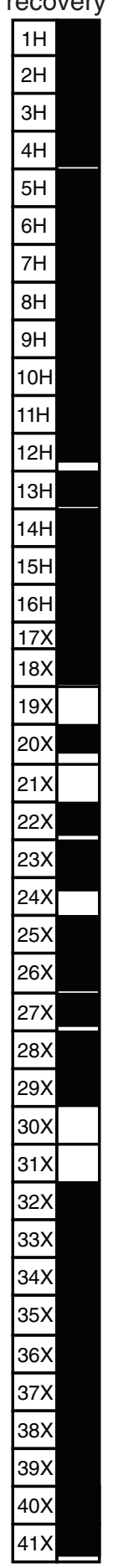

Relative moisture content (wt\%)

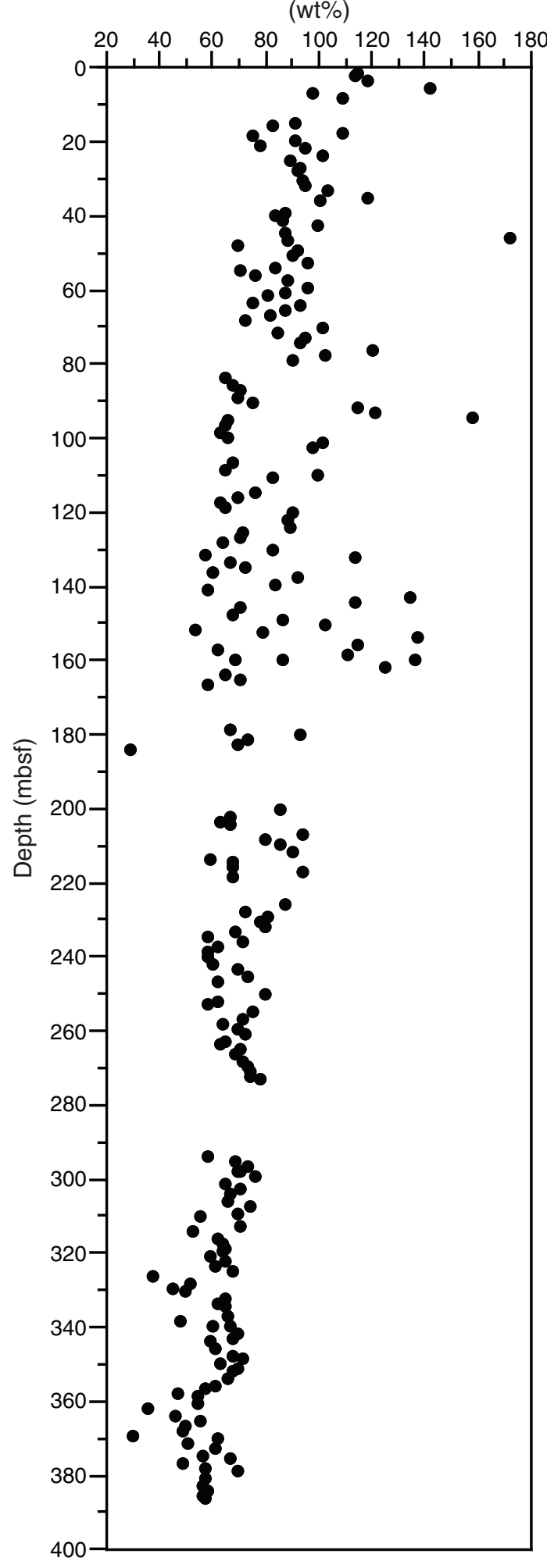

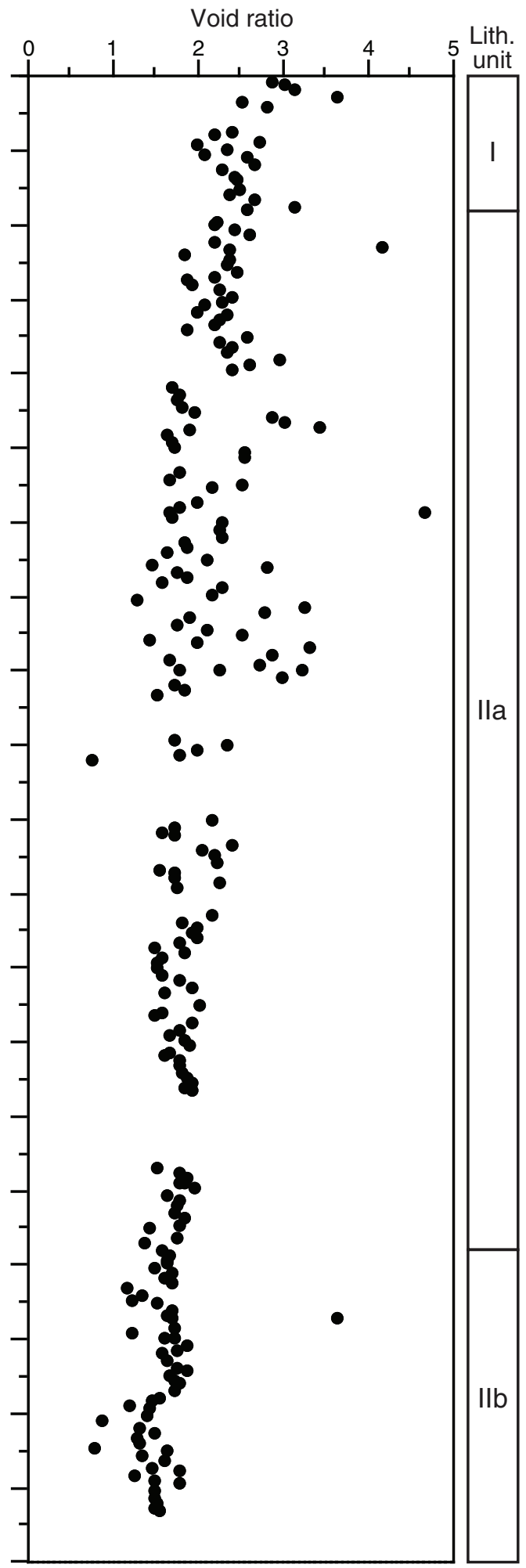


Figure F25. Plot of thermal conductivity measurements, Hole U1361A.

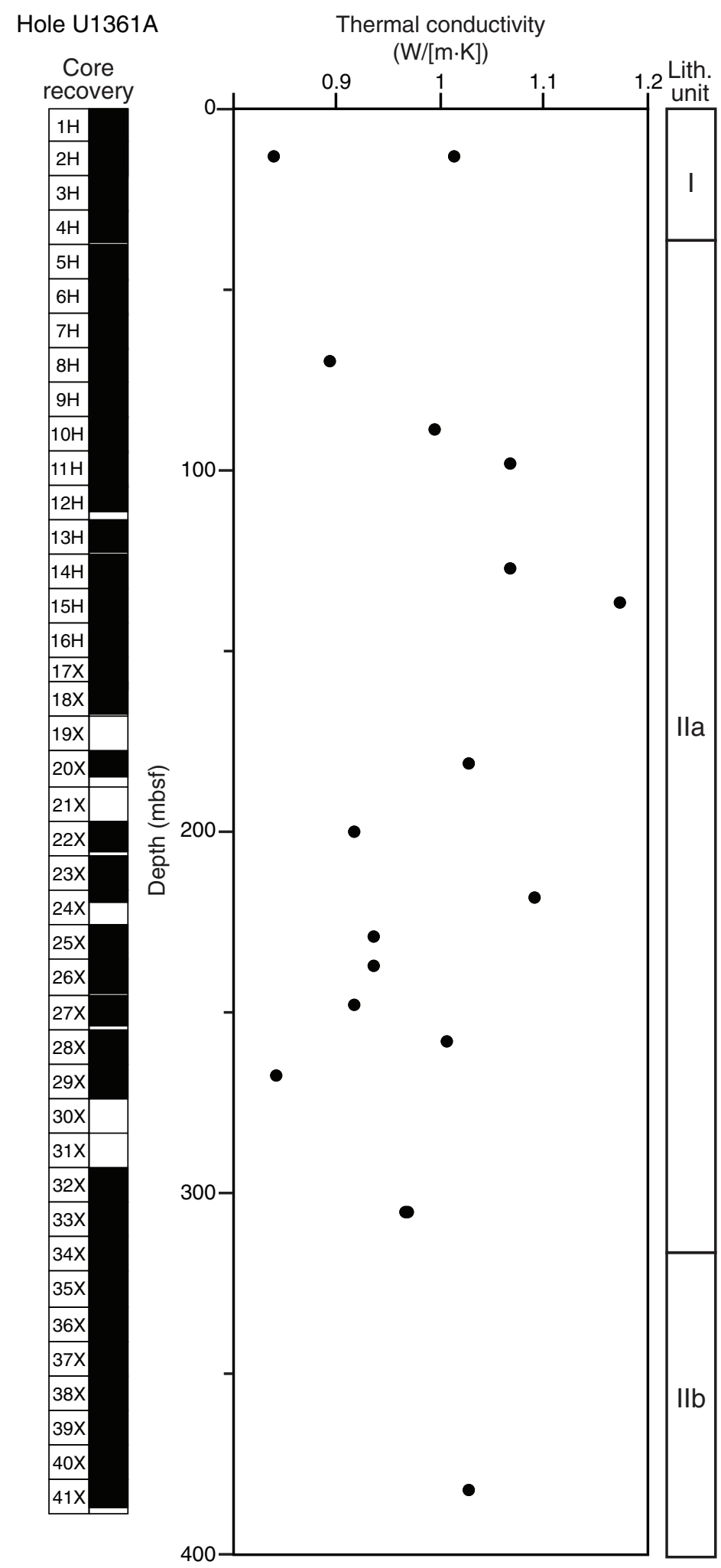




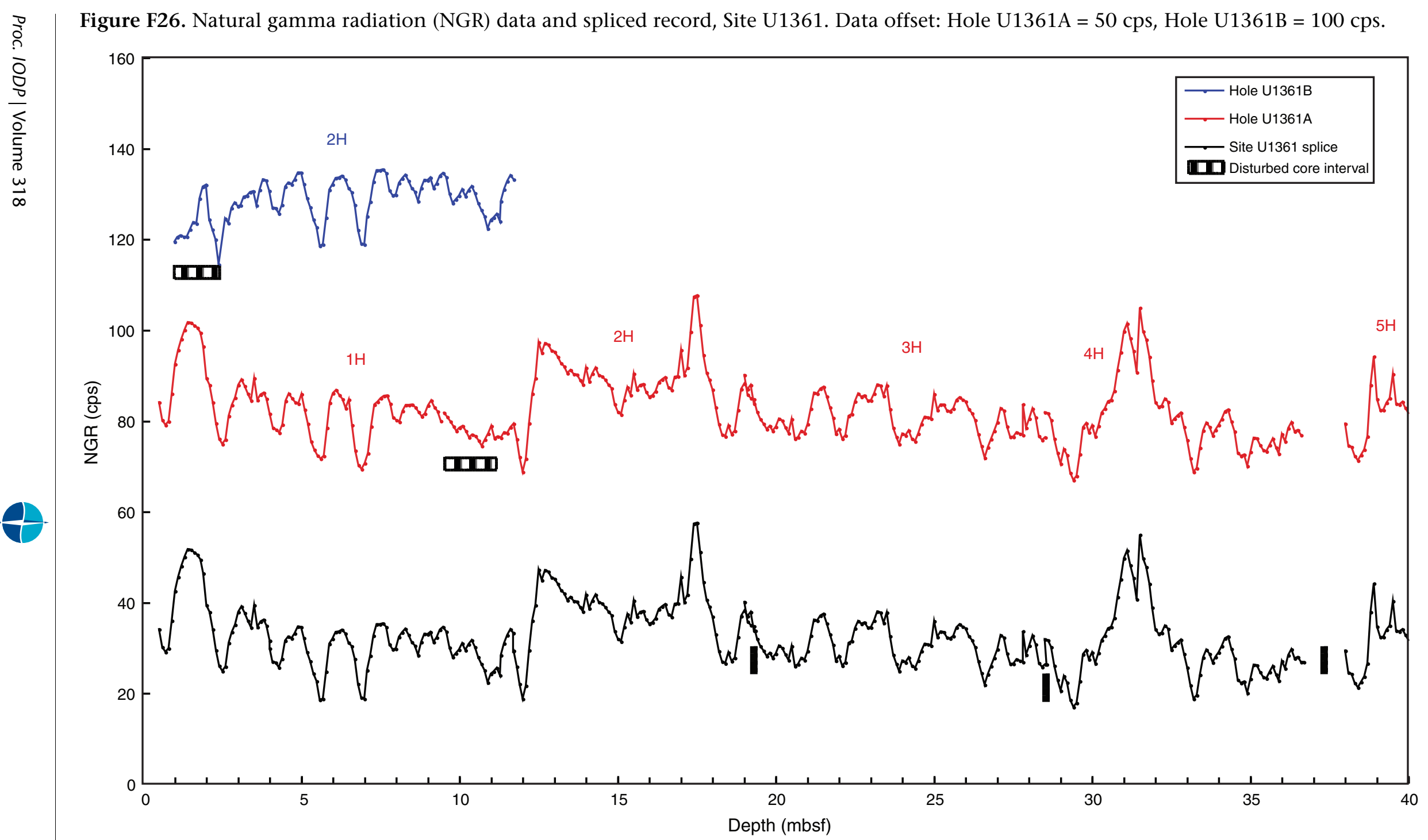




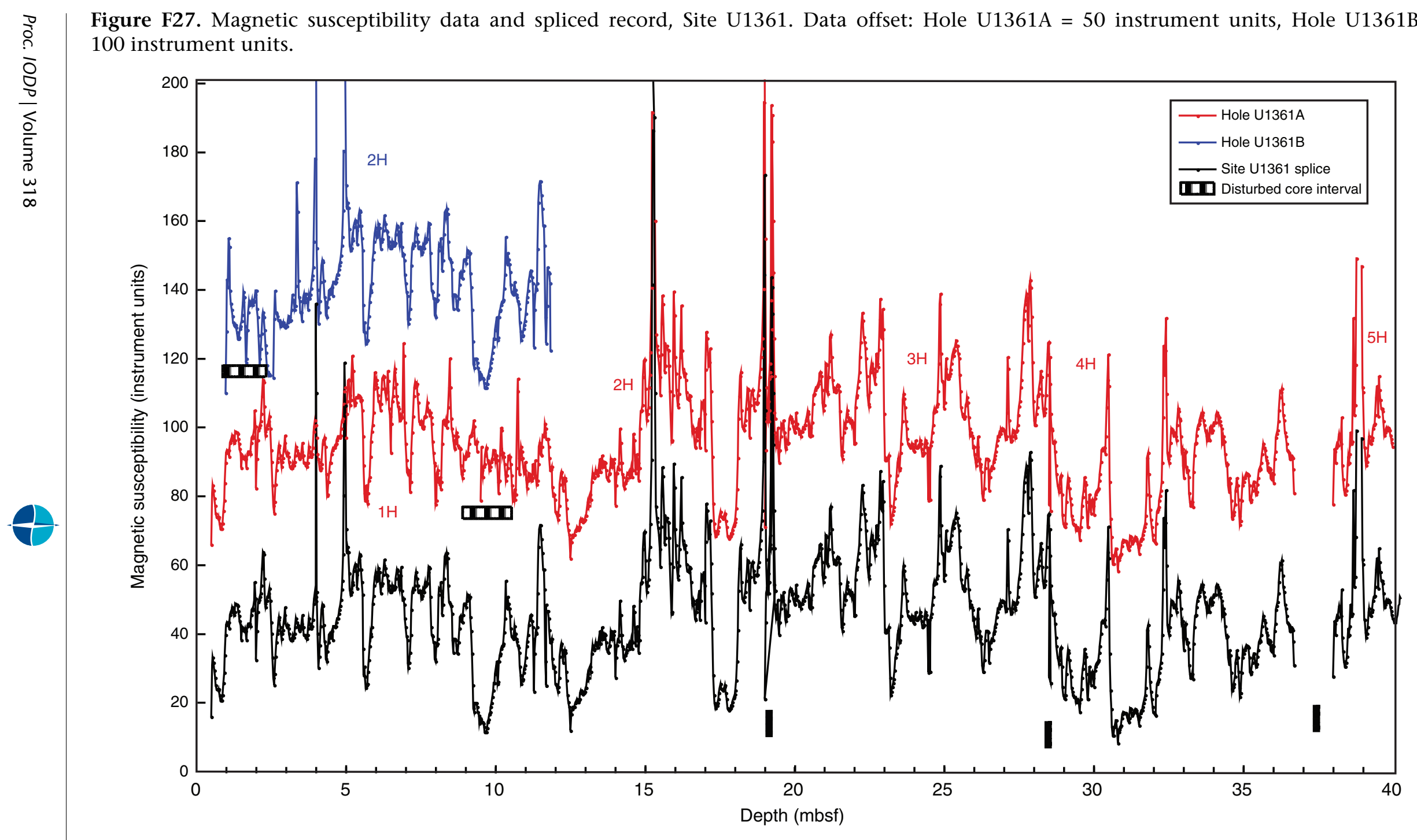


Figure F28. Logging operations summary diagram, Site U1361. Triple combo $=$ triple combination, FMS = Formation MicroScanner.

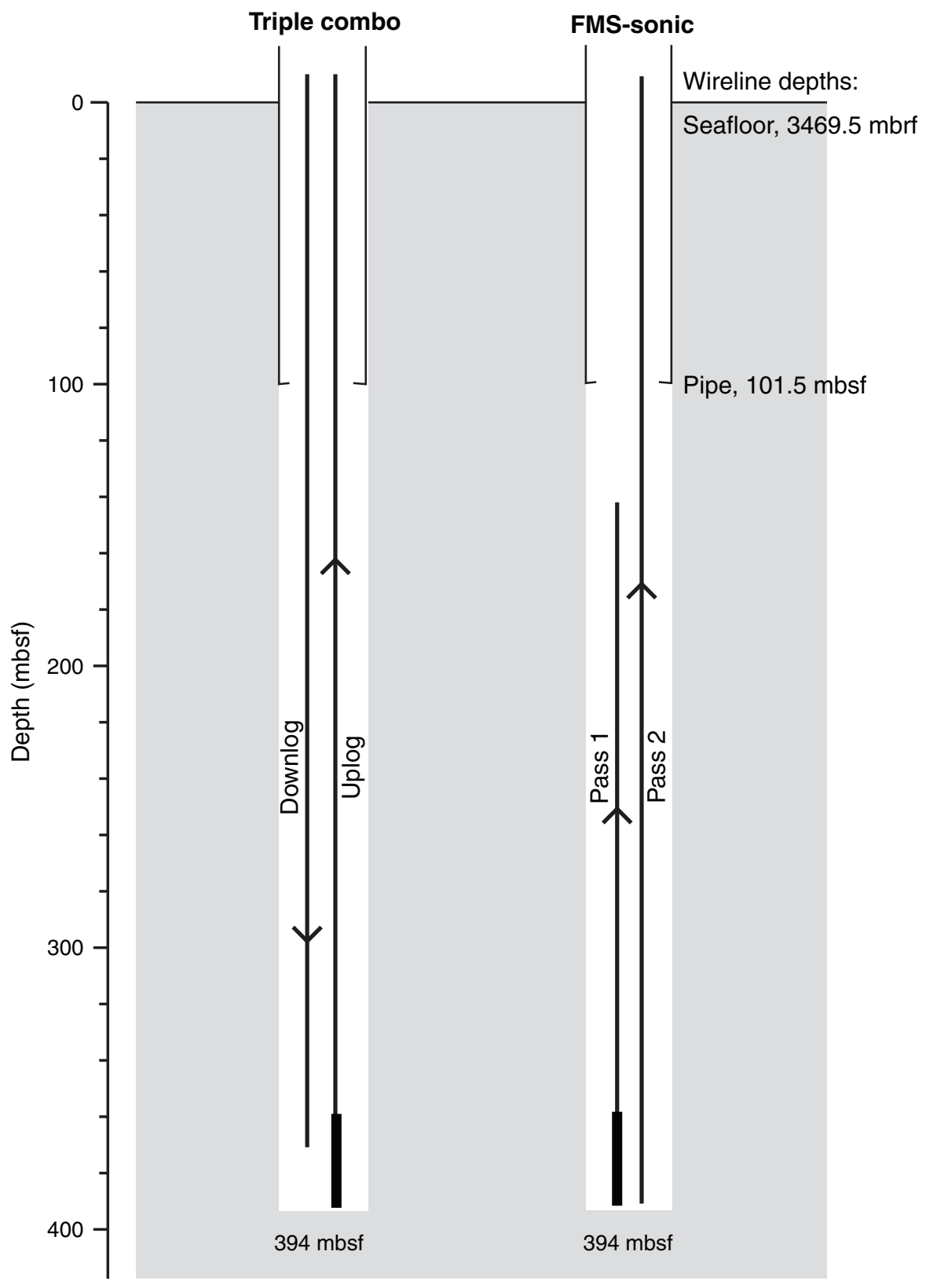


Figure F29. Downhole geophysical logs, Hole U1361A. HSGR = total spectral gamma ray, MAD = moisture and density, IDPH = deep induction phasor-processed resistivity, IMPH = medium induction phasor-processed resistivity, PWS-X $=x$-direction caliper.

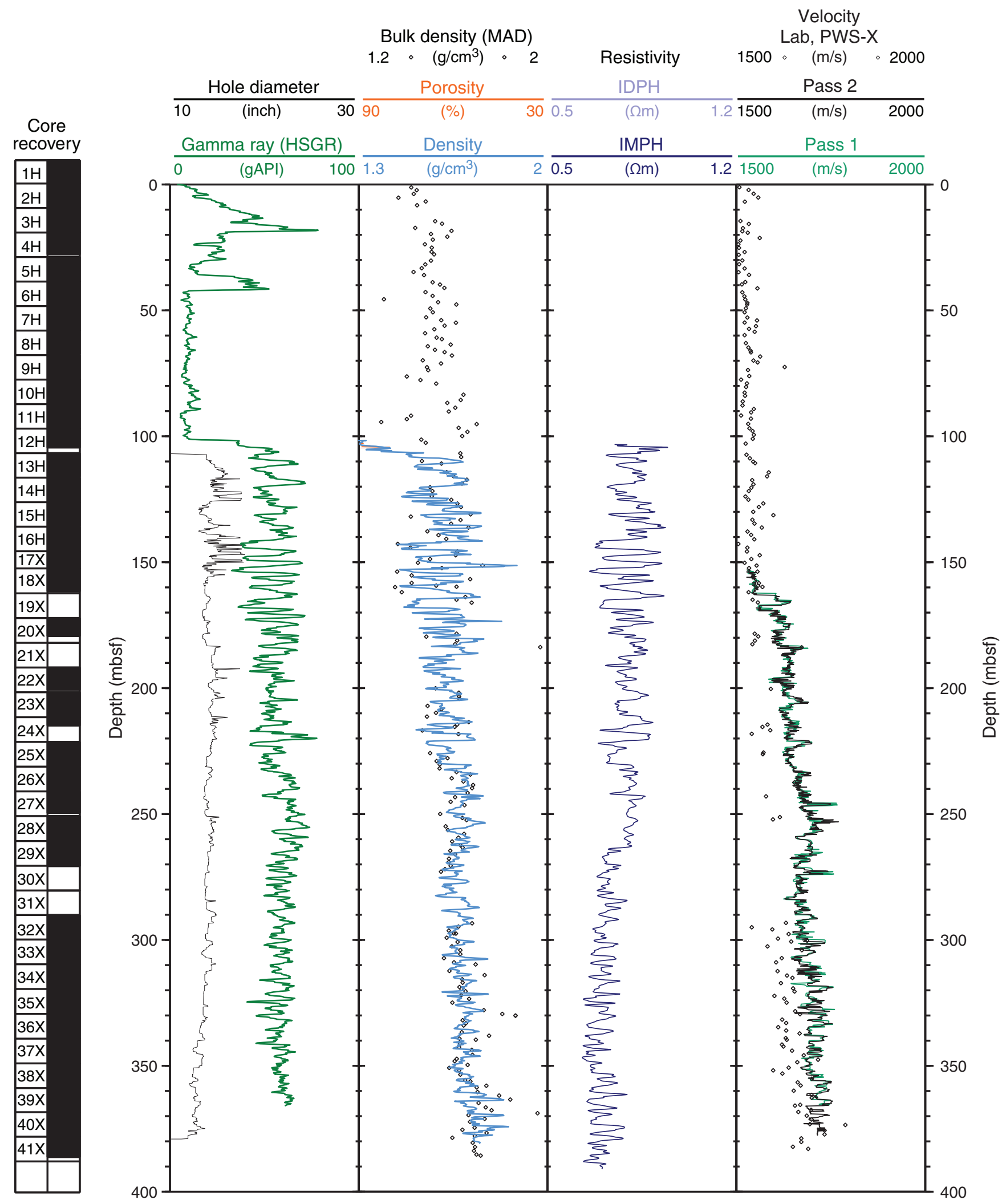


Figure F30. Natural gamma radiation (NGR) logs, Hole U1361A. HCGR = computed gamma ray, HSGR = total spectral gamma ray.

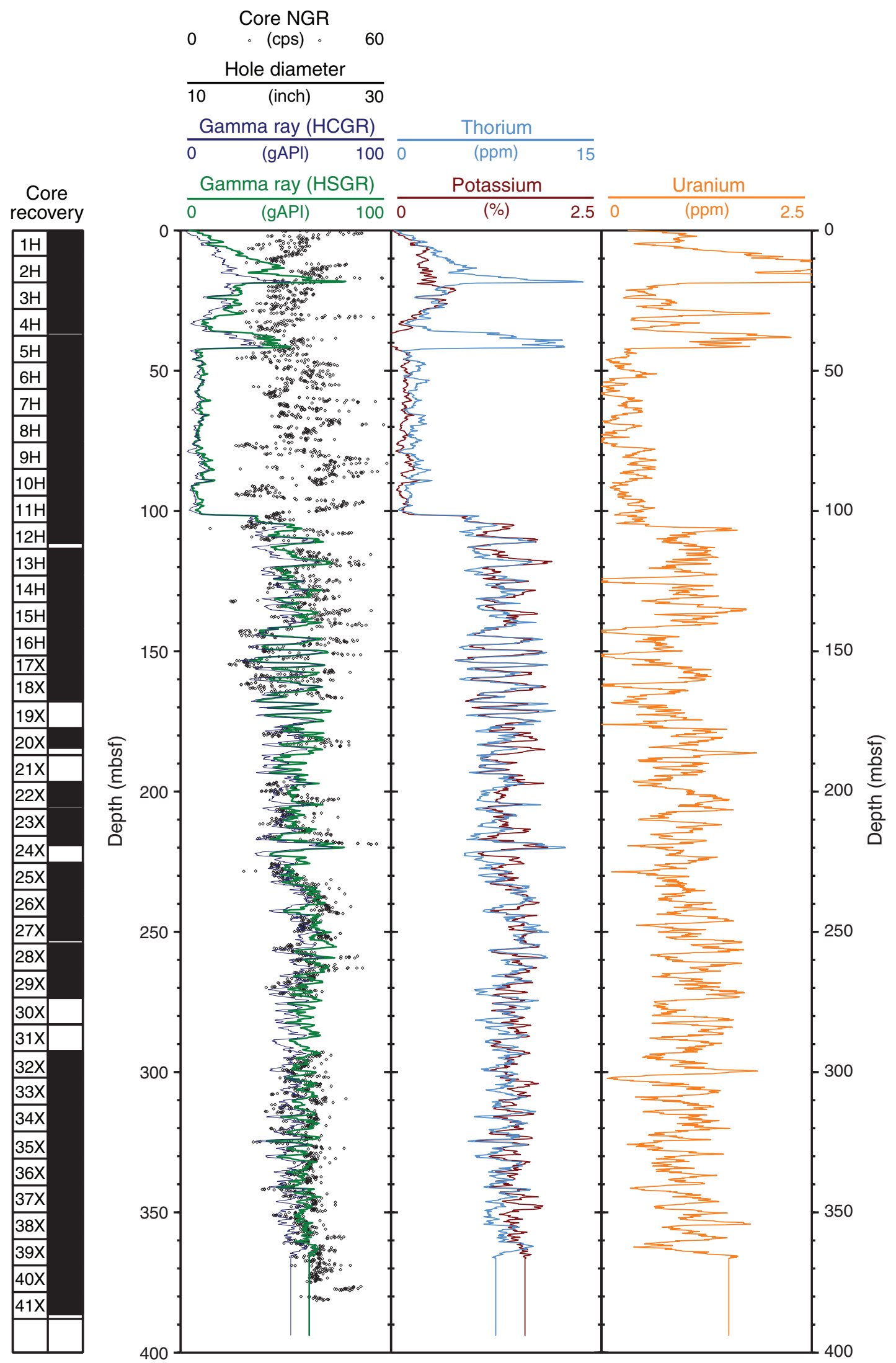


Figure F31. Comparison of downhole logs near the (A) top (130-180 mbsf) and (B) bottom (300-350 mbsf) of the logged interval of Hole U1361A, with correlation between gamma radiation and resistivity logs in A and anticorrelation in B. Grey bars = low NGR values thought to be caused by microfossil-rich sediment layers. The consecutive cycle count of these layers is given for the purpose of estimating the average duration of the alternations (see text). HSGR = total spectra gamma ray, SFLU = spherically focused resistivity, $\mathrm{IMPH}=$ medium induction phasor-processed resistivity.
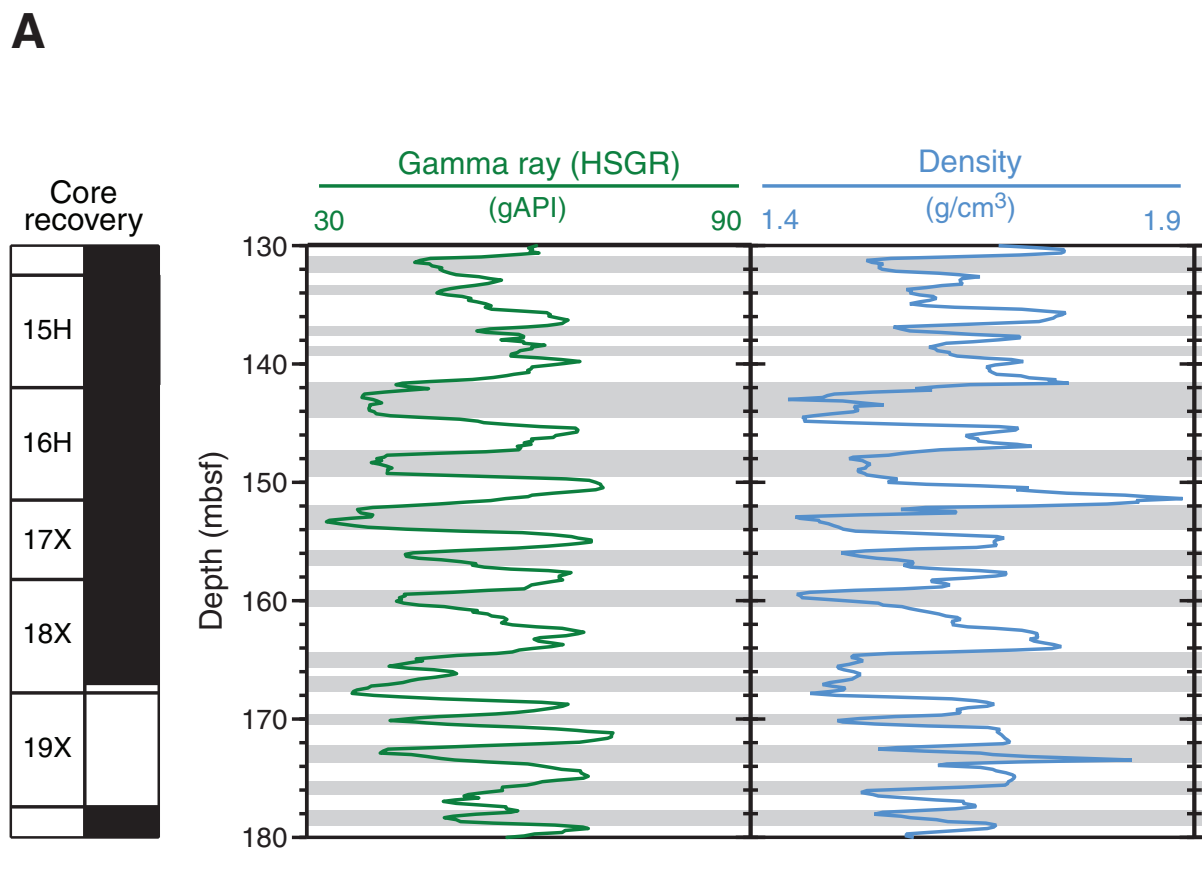

B
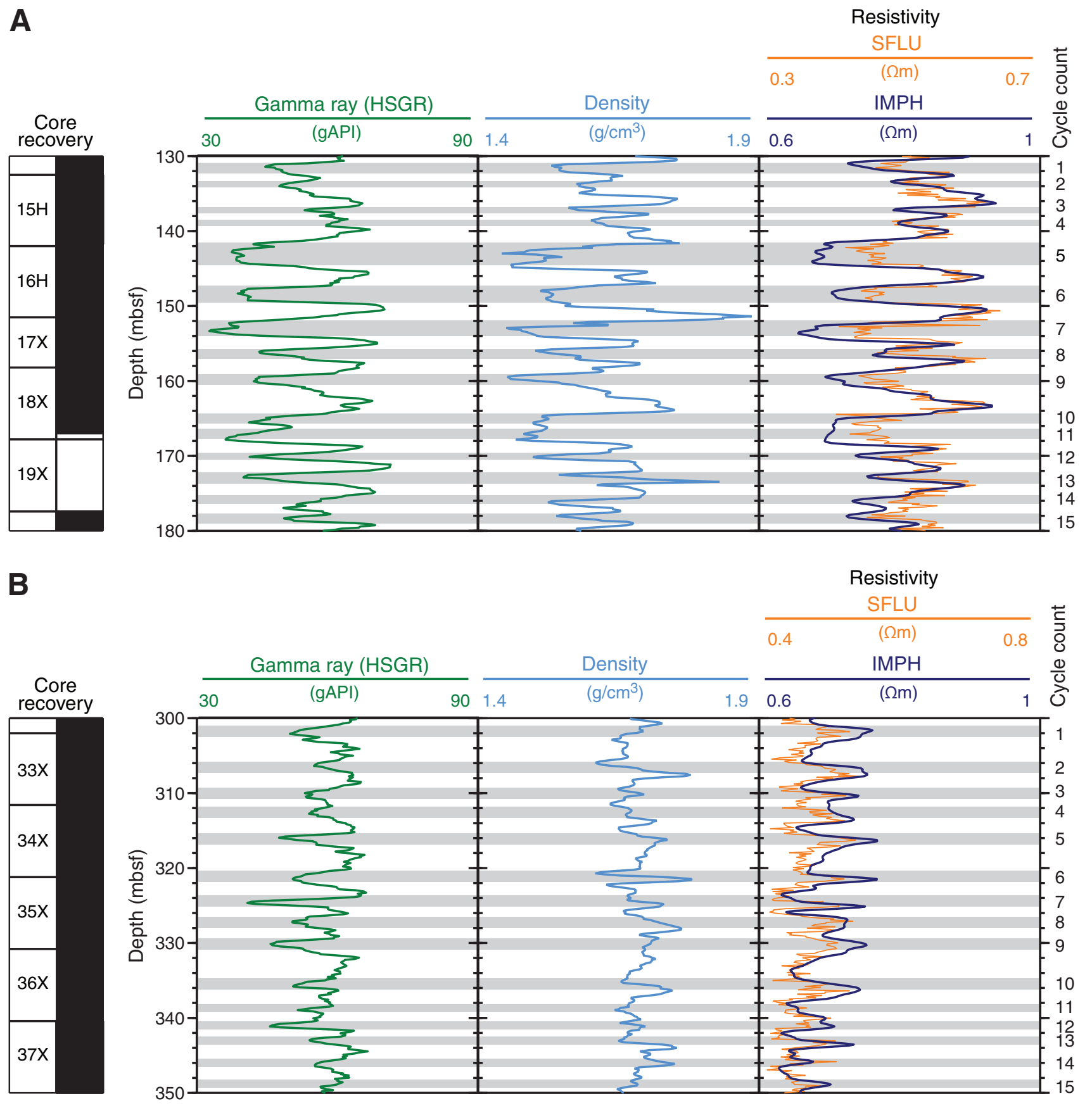
Figure F32. Examples of resistivity logs and Formation MicroScanner (FMS) resistivity images, Hole U1361A. A. Resistivity logs. SFLU = spherically focused resistivity, IMPH = medium induction phasor-processed resistivity. B. FMS image showing conductive (dark) and resistive (light) layers. C. A single conductive layer containing dropstones (light spots). The depth scales of the resistivity and FMS logs differ because both are on WSF depth scales before depth matching.

A

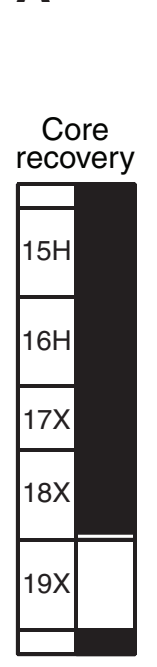

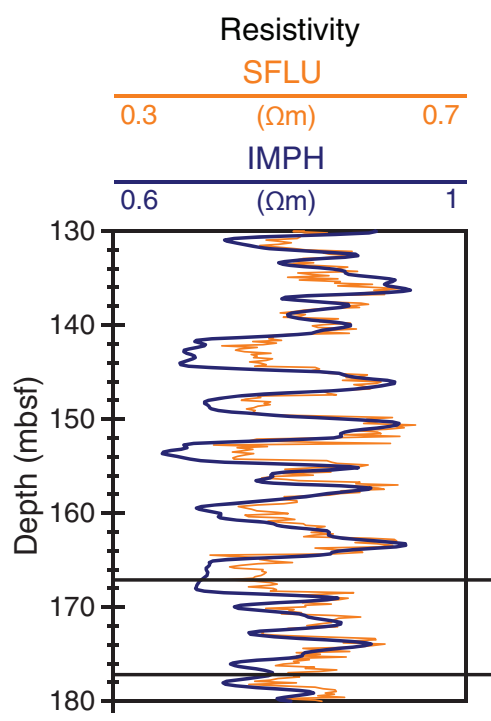

B
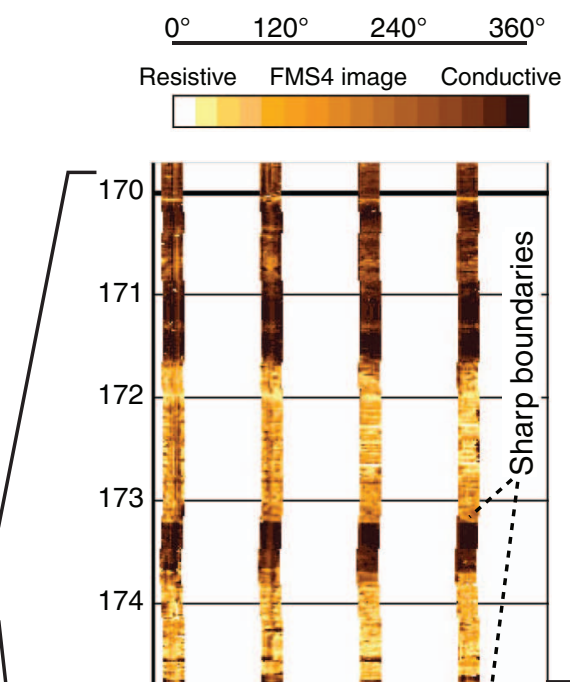

C
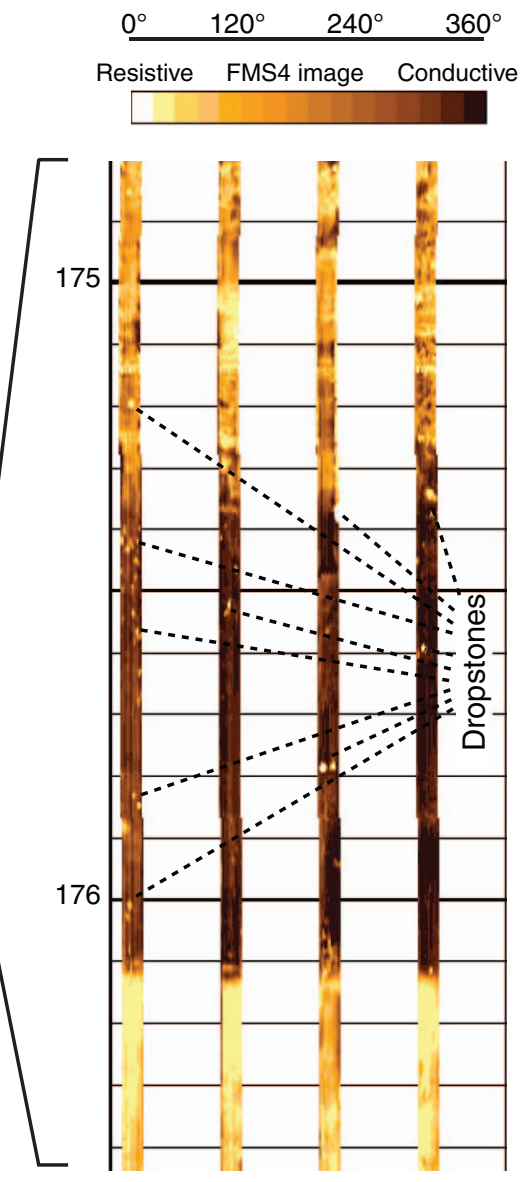
Figure F33. Diagrams of heat flow calculations, Hole U1361A. A. Advanced piston corer temperature tool (APCT-3) sediment temperatures. B. Temperature gradient. C. Bullard plot in which heat flow is calculated from a linear fit of the temperature data.
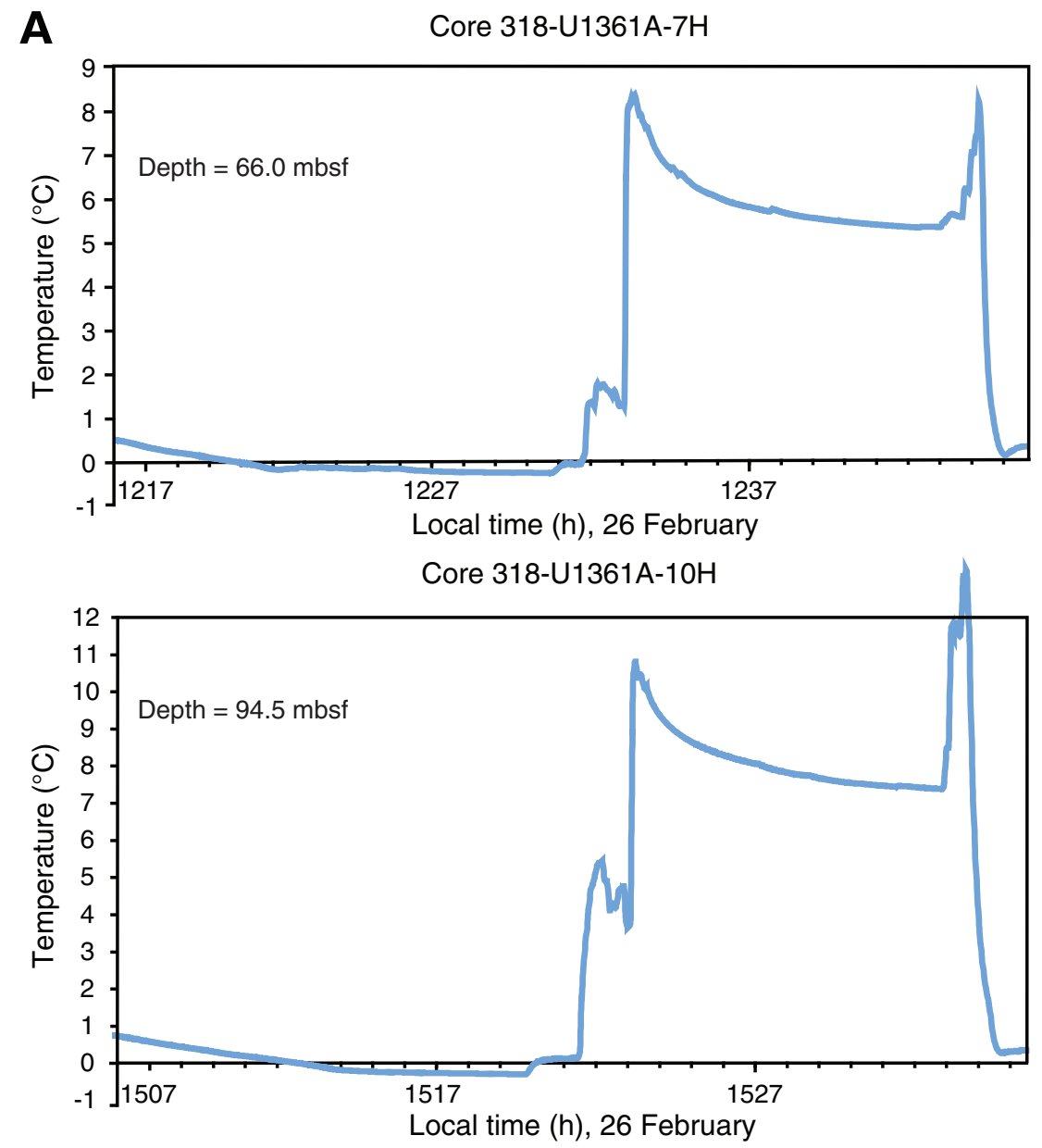

B

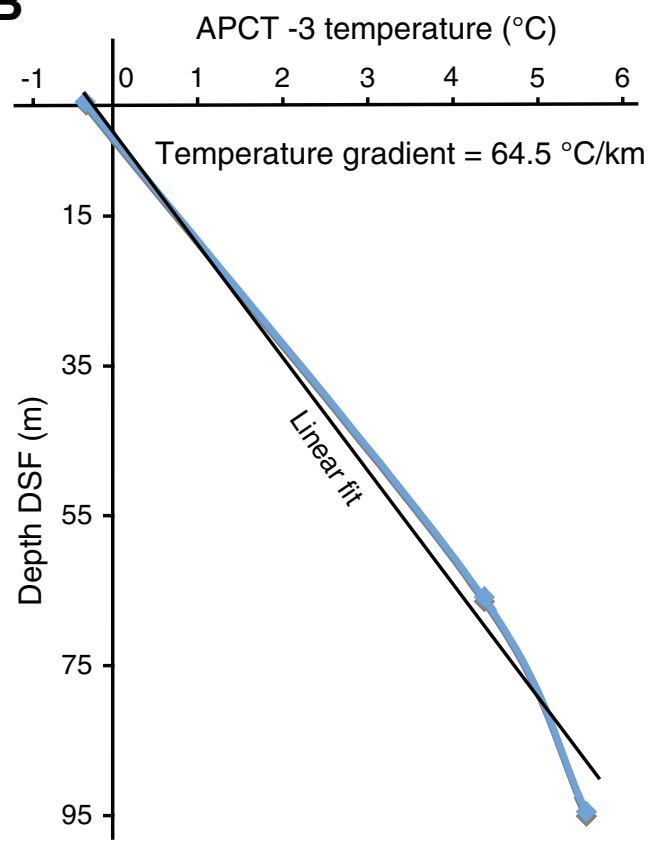

C

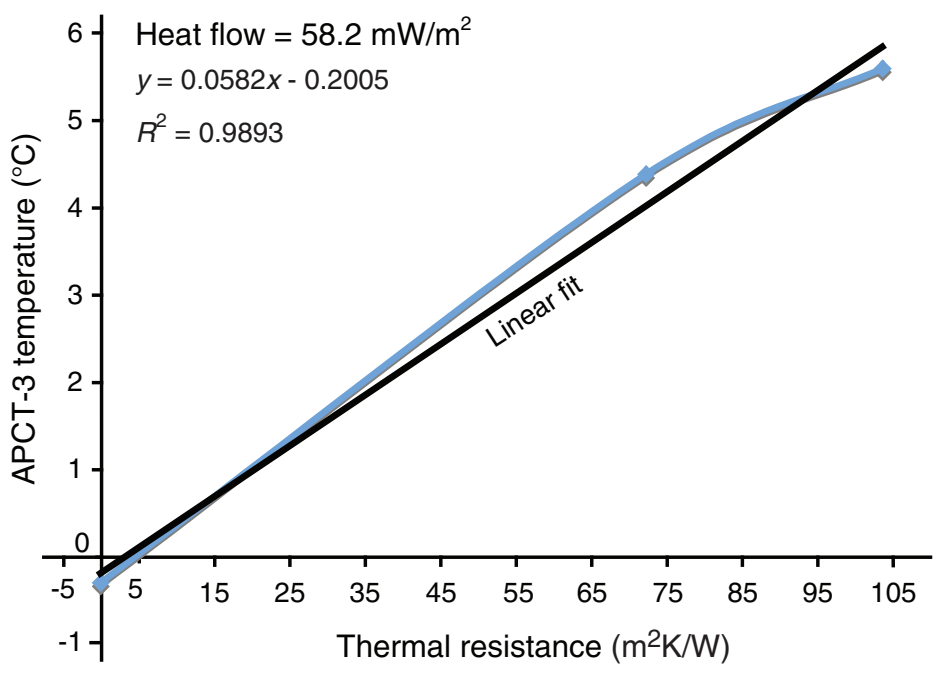


Table T1. Coring summary, Site U1361. (See table notes.) (Continued on next page.)

Site U1361

Time on site (h): 124.8 (1945 h, 25 February-0030 h, 3 March 2010)

Hole U1361A

Latitude: $64^{\circ} 24.5728^{\prime} \mathrm{S}$

Longitude: $143^{\circ} 53.1992^{\prime} \mathrm{E}$

Time on hole (h): 106.3 (1945 h, 25 February-0605 h, 2 March 2010)

Seafloor (drill pipe measurement from rig floor, $\mathrm{m} \mathrm{DRF):} 3465.5$

Distance between rig floor and sea level $(\mathrm{m}): 11.2$

Water depth (drill pipe measurement from sea level, m): 3454.3

Total penetration (m DSF): 388.0

Total depth (drill pipe measurement from rig floor, m DRF): 3853.5

Total length of cored section $(\mathrm{m}): 388.0$

Total core recovered $(\mathrm{m}): 338.9$

Core recovery (\%): 87

Total number of cores: 41

Hole U1361B

Latitude: $64^{\circ} 24.5454^{\prime} \mathrm{S}$

Longitude: $143^{\circ} 53.1966^{\prime} \mathrm{E}$

Time on hole (h): 18.4 (0605 h, 2 March-0030 h, 3 March 2010)

Seafloor (drill pipe measurement from rig floor, m DRF): 3466.9

Distance between rig floor and sea level $(\mathrm{m}): 11.2$

Water depth (drill pipe measurement from sea level, m): 3455.7

Total penetration (m DSF): 12.1

Total depth (drill pipe measurement from rig floor, m DRF): 3479.0

Total length of cored section $(\mathrm{m}): 12.1$

Total core recovered $(\mathrm{m}): 12.0$

Core recovery (\%): 100

Total number of cores: 2

\begin{tabular}{|c|c|c|c|c|c|c|c|c|c|}
\hline \multirow[b]{2}{*}{ Core } & \multirow[b]{2}{*}{$\begin{array}{l}\text { Date } \\
(2010)\end{array}$} & \multirow[b]{2}{*}{$\begin{array}{l}\text { Local time } \\
\text { (h) }\end{array}$} & \multicolumn{2}{|c|}{ Depth DSF-B (m) } & \multirow[b]{2}{*}{$\begin{array}{l}\text { Interval } \\
\text { advanced } \\
(\mathrm{m})\end{array}$} & \multicolumn{2}{|c|}{ Depth CSF-A (m) } & \multirow[b]{2}{*}{$\begin{array}{l}\text { Length of core } \\
\text { recovered } \\
(\mathrm{m})\end{array}$} & \multirow[b]{2}{*}{$\begin{array}{c}\text { Recovery } \\
\text { (\%) }\end{array}$} \\
\hline & & & $\begin{array}{l}\text { Top of } \\
\text { cored } \\
\text { interval }\end{array}$ & $\begin{array}{l}\text { Bottom of } \\
\text { cored } \\
\text { interval }\end{array}$ & & $\begin{array}{l}\text { Top of } \\
\text { cored } \\
\text { interval }\end{array}$ & $\begin{array}{l}\text { Bottom of } \\
\text { cored } \\
\text { interval }\end{array}$ & & \\
\hline \multicolumn{10}{|c|}{ 318-U1361A- } \\
\hline $1 \mathrm{H}$ & $26 \mathrm{Feb}$ & 0730 & 0.0 & 9.0 & 9.0 & 0.00 & 9.03 & 9.03 & 100 \\
\hline $2 \mathrm{H}$ & $26 \mathrm{Feb}$ & 0830 & 9.0 & 18.5 & 9.5 & 9.00 & 19.04 & 10.04 & 106 \\
\hline $3 \mathrm{H}$ & $26 \mathrm{Feb}$ & 0925 & 18.5 & 28.0 & 9.5 & 18.50 & 28.26 & 9.76 & 103 \\
\hline $4 \mathrm{H}$ & $26 \mathrm{Feb}$ & 1020 & 28.0 & 37.5 & 9.5 & 28.00 & 36.53 & 8.53 & 90 \\
\hline $5 \mathrm{H}$ & $26 \mathrm{Feb}$ & 1115 & 37.5 & 47.0 & 9.5 & 37.50 & 47.42 & 9.92 & 104 \\
\hline $6 \mathrm{H}$ & $26 \mathrm{Feb}$ & 1205 & 47.0 & 56.5 & 9.5 & 47.00 & 56.72 & 9.72 & 102 \\
\hline $7 \mathrm{H}$ & $26 \mathrm{Feb}$ & 1310 & 56.5 & 66.0 & 9.5 & 56.50 & 66.55 & 10.05 & 106 \\
\hline $8 \mathrm{H}$ & $26 \mathrm{Feb}$ & 1405 & 66.0 & 75.5 & 9.5 & 66.00 & 75.17 & 9.17 & 97 \\
\hline $9 \mathrm{H}$ & $26 \mathrm{Feb}$ & 1450 & 75.5 & 85.0 & 9.5 & 75.50 & 85.49 & 9.99 & 105 \\
\hline $10 \mathrm{H}$ & $26 \mathrm{Feb}$ & 1600 & 85.0 & 94.5 & 9.5 & 85.00 & 94.99 & 9.99 & 105 \\
\hline $11 \mathrm{H}$ & 26 Feb & 1645 & 94.5 & 104.0 & 9.5 & 94.50 & 104.26 & 9.76 & 103 \\
\hline $12 \mathrm{H}$ & 26 Feb & 1735 & 104.0 & 113.5 & 9.5 & 104.00 & 111.32 & 7.32 & 77 \\
\hline $13 \mathrm{H}$ & 26 Feb & 1845 & 113.5 & 123.0 & 9.5 & 113.50 & 122.57 & 9.07 & 95 \\
\hline $14 \mathrm{H}$ & $26 \mathrm{Feb}$ & 1925 & 123.0 & 132.5 & 9.5 & 123.00 & 132.57 & 9.57 & 101 \\
\hline $15 \mathrm{H}$ & 26 Feb & 2010 & 132.5 & 142.0 & 9.5 & 132.50 & 141.76 & 9.26 & 97 \\
\hline $16 \mathrm{H}$ & $26 \mathrm{Feb}$ & 2100 & 142.0 & 151.5 & 9.5 & 142.00 & 151.70 & 9.70 & 102 \\
\hline $17 X$ & $26 \mathrm{Feb}$ & 2235 & 151.5 & 158.2 & 6.7 & 151.50 & 160.34 & 8.84 & 132 \\
\hline $18 \mathrm{X}$ & $26 \mathrm{Feb}$ & 2340 & 158.2 & 167.8 & 9.6 & 158.20 & 167.10 & 8.90 & 93 \\
\hline $19 x$ & 27 Feb & 0040 & 167.8 & 177.4 & 9.6 & 167.80 & 167.80 & 0.00 & 0 \\
\hline $20 x$ & 27 Feb & 0150 & 177.4 & 187.0 & 9.6 & 177.40 & 184.41 & 7.01 & 73 \\
\hline $21 x$ & 27 Feb & 0255 & 187.0 & 196.6 & 9.6 & 187.00 & 187.00 & 0.00 & 0 \\
\hline $22 x$ & 27 Feb & 0405 & 196.6 & 206.2 & 9.6 & 196.60 & 205.21 & 8.61 & 90 \\
\hline $23 x$ & 27 Feb & 0510 & 206.2 & 215.8 & 9.6 & 206.20 & 215.90 & 9.70 & 101 \\
\hline $24 X$ & 27 Feb & 0605 & 215.8 & 225.4 & 9.6 & 215.80 & 219.12 & 3.32 & 35 \\
\hline $25 X$ & 27 Feb & 0715 & 225.4 & 235.0 & 9.6 & 225.40 & 234.82 & 9.42 & 98 \\
\hline $26 X$ & 27 Feb & 0840 & 235.0 & 244.6 & 9.6 & 235.00 & 244.24 & 9.24 & 96 \\
\hline $27 X$ & 27 Feb & 1000 & 244.6 & 254.2 & 9.6 & 244.60 & 253.02 & 8.42 & 88 \\
\hline $28 X$ & 27 Feb & 1055 & 254.2 & 263.8 & 9.6 & 254.20 & 263.91 & 9.71 & 101 \\
\hline $29 X$ & 27 Feb & 1143 & 263.8 & 273.4 & 9.6 & 263.80 & 273.42 & 9.62 & 100 \\
\hline $30 x$ & 27 Feb & 1245 & 273.4 & 283.0 & 9.6 & 273.40 & 273.55 & 0.15 & 2 \\
\hline $31 x$ & 27 Feb & 1340 & 283.0 & 292.5 & 9.5 & 283.00 & 283.09 & 0.09 & 1 \\
\hline $32 x$ & 27 Feb & 1615 & 292.5 & 302.0 & 9.5 & 292.50 & 302.10 & 9.60 & 101 \\
\hline $33 x$ & 27 Feb & 1710 & 302.0 & 311.6 & 9.6 & 302.00 & 311.68 & 9.68 & 101 \\
\hline $34 X$ & 27 Feb & 1820 & 311.6 & 321.2 & 9.6 & 311.60 & 321.07 & 9.47 & 99 \\
\hline $35 x$ & 27 Feb & 1930 & 321.2 & 330.8 & 9.6 & 321.20 & 331.03 & 9.83 & 102 \\
\hline
\end{tabular}


Table T1 (continued).

\begin{tabular}{|c|c|c|c|c|c|c|c|c|c|}
\hline \multirow[b]{2}{*}{ Core } & \multirow[b]{2}{*}{$\begin{array}{l}\text { Date } \\
(2010)\end{array}$} & \multirow[b]{2}{*}{$\begin{array}{l}\text { Local time } \\
\text { (h) }\end{array}$} & \multicolumn{2}{|c|}{ Depth DSF-B (m) } & \multirow[b]{2}{*}{$\begin{array}{l}\text { Interval } \\
\text { advanced } \\
(\mathrm{m})\end{array}$} & \multicolumn{2}{|c|}{ Depth CSF-A (m) } & \multirow[b]{2}{*}{$\begin{array}{l}\text { Length of core } \\
\text { recovered } \\
\text { (m) }\end{array}$} & \multirow[b]{2}{*}{$\begin{array}{c}\text { Recovery } \\
(\%)\end{array}$} \\
\hline & & & $\begin{array}{l}\text { Top of } \\
\text { cored } \\
\text { interval }\end{array}$ & $\begin{array}{l}\text { Bottom of } \\
\text { cored } \\
\text { interval }\end{array}$ & & $\begin{array}{l}\text { Top of } \\
\text { cored } \\
\text { interval }\end{array}$ & $\begin{array}{l}\text { Bottom of } \\
\text { cored } \\
\text { interval }\end{array}$ & & \\
\hline $36 X$ & 27 Feb & 2020 & 330.8 & 340.4 & 9.6 & 330.80 & 340.41 & 9.61 & 100 \\
\hline $37 X$ & 27 Feb & 2120 & 340.4 & 350.0 & 9.6 & 340.40 & 349.99 & 9.59 & 100 \\
\hline $38 \mathrm{x}$ & 27 Feb & 2215 & 350.0 & 359.6 & 9.6 & 350.00 & 359.78 & 9.78 & 102 \\
\hline $39 x$ & 27 Feb & 2310 & 359.6 & 368.9 & 9.3 & 359.60 & 369.26 & 9.66 & 104 \\
\hline $40 x$ & 28 Feb & 0010 & 368.9 & 378.4 & 9.5 & 368.90 & 378.72 & 9.82 & 103 \\
\hline \multirow[t]{2}{*}{$41 X$} & $28 \mathrm{Feb}$ & 0120 & 378.4 & 388.0 & 9.6 & 378.40 & 386.31 & 7.91 & 82 \\
\hline & & & Total in & $\begin{array}{l}\text { Cored totals: } \\
\text { terval cored: }\end{array}$ & $\begin{array}{l}388.0 \\
388.0\end{array}$ & & & 338.9 & 87 \\
\hline \multicolumn{10}{|c|}{ 318-U1361B- } \\
\hline $1 \mathrm{H}$ & 2 Mar & 0900 & 0.0 & 2.6 & 2.6 & 0.00 & 2.64 & 2.64 & 102 \\
\hline \multirow[t]{2}{*}{$2 \mathrm{H}$} & $2 \mathrm{Mar}$ & 1115 & 2.6 & 12.1 & 9.5 & 2.60 & 12.00 & 9.40 & 99 \\
\hline & & & Total in & $\begin{array}{l}\text { Cored totals: } \\
\text { terval cored: }\end{array}$ & $\begin{array}{l}12.1 \\
12.1\end{array}$ & & & 12.0 & 100 \\
\hline
\end{tabular}

Notes: DRF $=$ drilling depth below rig floor. DSF-B $=$ drilling depth below seafloor determined by mudline core recovery, CSF-A $=$ core depth below seafloor, overlap if long. Local time $=$ UTC $+11 \mathrm{~h}$.

Table T2. Siliceous microfossil abundance and preservation, Holes U1361A and U1361B. This table is available in an oversized format.

Table T3. Calcareous nannofossil abundance and preservation, Hole U1361A. (See table notes.)

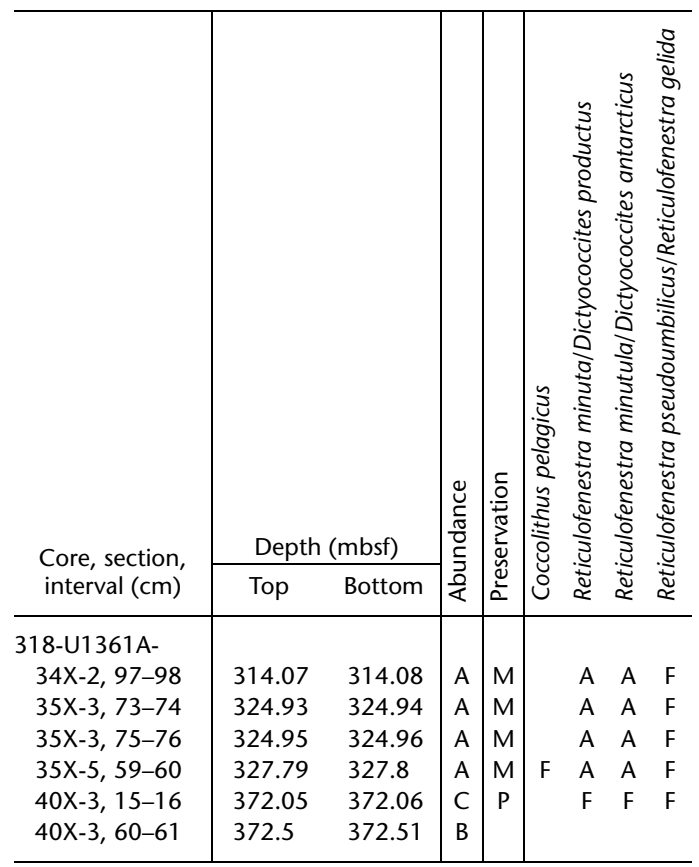

Notes: Abundance: $A=$ abundant,$C=$ common, $F=$ few, $B=$ barren. Preservation: $M=$ moderate, $P=$ poor. See "Biostratigraphy" in the "Methods" chapter for abundance and preservation definitions. 
Table T4. Palynology, Hole U1361A. (See table notes.)

\begin{tabular}{|c|c|c|c|c|c|c|c|c|c|c|c|c|c|c|c|c|c|c|c|c|c|c|}
\hline \multirow{2}{*}{$\begin{array}{l}\text { Core, section, } \\
\text { interval }(\mathrm{cm})\end{array}$} & \multicolumn{2}{|c|}{ Depth (mbsf) } & \multirow{2}{*}{ 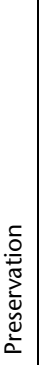 } & \multirow{2}{*}{ 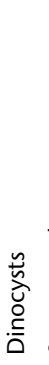 } & \multirow{2}{*}{ 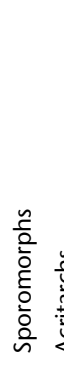 } & \multirow{2}{*}{\multicolumn{2}{|c|}{ 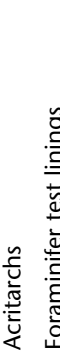 }} & \multirow[t]{2}{*}{ 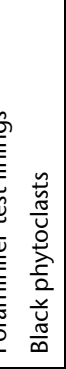 } & \multirow[t]{2}{*}{ 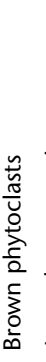 } & \multirow[t]{2}{*}{ 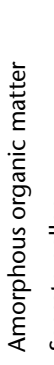 } & \multirow[t]{2}{*}{ 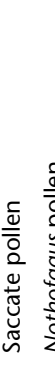 } & \multirow{2}{*}{\multicolumn{2}{|c|}{ 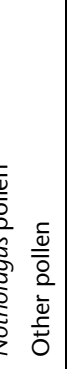 }} & \multirow{2}{*}{\multicolumn{2}{|c|}{ 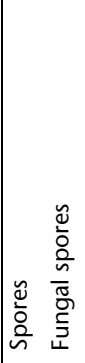 }} & \multirow[t]{2}{*}{ 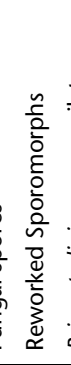 } & \multirow{2}{*}{\multicolumn{2}{|c|}{ 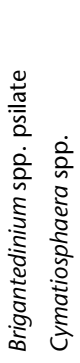 }} & & \multirow[t]{2}{*}{ 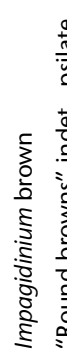 } & \multirow[t]{2}{*}{ 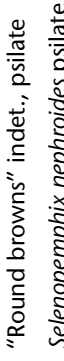 } & 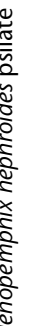 \\
\hline & Top & Bottom & & & & & & & & & & & & & & & & & & & & \\
\hline $\begin{array}{l}\text { 318-U1361A- } \\
1 \mathrm{H}-\mathrm{CC}, 5-12\end{array}$ & 8.96 & 9.03 & $\mathrm{P}$ & B & A & B & B & C & C & T & $\mathrm{F}$ & B & T & A & B & 57 & & & & & & \\
\hline $6 \mathrm{H}-\mathrm{CC}, 17-22$ & 56.68 & 56.72 & $\mathrm{P}$ & B & A & B & B & $\mathrm{F}$ & $\mathrm{F}$ & $\mathrm{T}$ & $\mathrm{F}$ & B & $\mathrm{T}$ & A & B & 34 & & & & & & \\
\hline $10 \mathrm{H}-\mathrm{CC}, 19-24$ & 94.94 & 94.99 & $\mathrm{P}$ & $\mathrm{T}$ & $\mathrm{T}$ & B & B & T & $\mathrm{T}$ & B & B & B & B & T & B & 3 & 2 & & & & & \\
\hline $14 \mathrm{H}-\mathrm{CC}, 12-16$ & 132.53 & 132.57 & $\mathrm{P}$ & B & T & B & B & T & $\mathrm{T}$ & B & B & B & B & T & B & 9 & & & & & & \\
\hline $17 X-C C, 21-26$ & 160.29 & 160.34 & $\mathrm{P}$ & $\mathrm{F}$ & A & B & B & T & $\mathrm{T}$ & T & $\mathrm{F}$ & T & B & A & B & 54 & 7 & & & & & \\
\hline 22X-CC, $14-19$ & 205.16 & 205.21 & $\mathrm{P}$ & B & $\mathrm{T}$ & B & B & T & $\mathrm{T}$ & B & B & B & B & $\mathrm{T}$ & B & 1 & & & & & & \\
\hline 25X-CC, 13-18 & 234.77 & 234.82 & $\mathrm{P}$ & B & A & B & B & T & T & B & C & B & B & A & B & 62 & 6 & & 3 & & & \\
\hline 29X-CC, 16-21 & 273.37 & 273.42 & M & $\mathrm{F}$ & $\mathrm{T}$ & B & B & T & $\mathrm{T}$ & $\mathrm{T}$ & B & B & B & $\mathrm{T}$ & B & 3 & 3 & & & 2 & & 2 \\
\hline 33X-CC, 14-19 & 311.62 & 311.68 & $\mathrm{P}$ & T & T & B & B & T & T & T & $\mathrm{T}$ & B & B & T & B & 3 & 1 & & & & & 1 \\
\hline $39 X-C C, 19-24$ & 369.21 & 369.26 & M & $\mathrm{T}$ & $\mathrm{F}$ & T & T & T & $\mathrm{F}$ & B & T & B & B & $\mathrm{F}$ & B & 13 & 6 & & & 1 & 4 & 1 \\
\hline
\end{tabular}

Notes: Preservation: $\mathrm{M}=$ medium, $\mathrm{P}=$ poor. Abundance: $\mathrm{A}=$ abundant, $\mathrm{C}=$ common, $\mathrm{F}=$ few, $\mathrm{T}=$ trace, $\mathrm{B}=$ barren. See "Biostratigraphy" in the "Methods" chapter for preservation and abundance definitions. 
Table T5. Foraminifer abundance, Hole U1361A. (See table notes.)

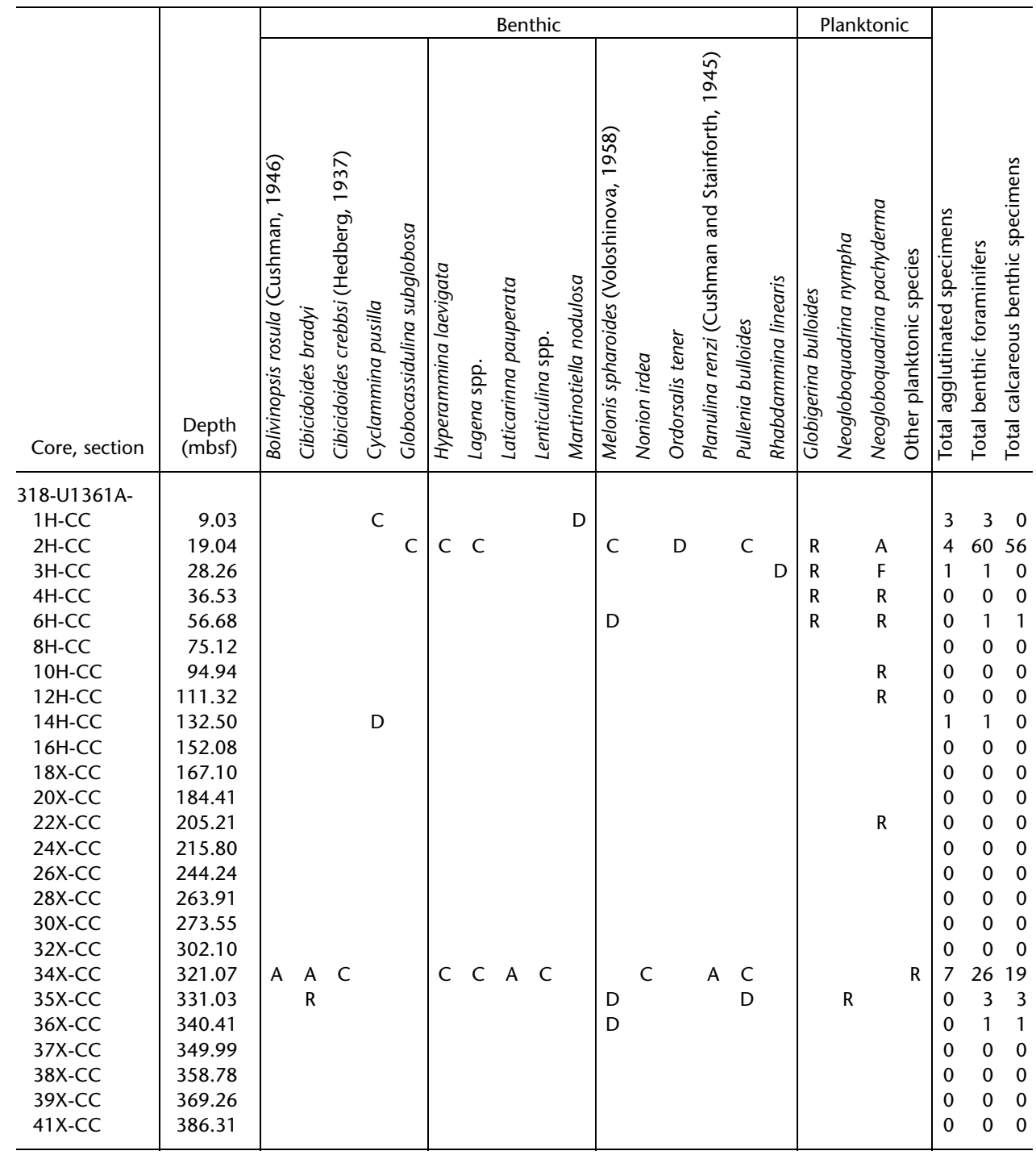

Notes: Abundance: $D=$ dominant, $A=$ abundant, $C=$ common, $F=$ few, $R=$ rare. See "Biostratigraphy" in the "Methods" chapter for abundance definitions. 
Table T6. Biostratigraphic events and chronostratigraphy, Site U1361. (See table notes.)

\begin{tabular}{|c|c|c|c|c|c|c|c|c|c|}
\hline \multirow[b]{3}{*}{ Type } & \multirow[b]{3}{*}{ Events } & \multicolumn{2}{|c|}{ Age } & \multirow{2}{*}{\multicolumn{2}{|c|}{ Core, section, interval $(\mathrm{cm})$}} & \multirow{2}{*}{\multicolumn{3}{|c|}{ Depth (mbsf) }} & \multirow{3}{*}{$\begin{array}{l}\text { Depth } \\
\text { error } \\
\text { (m) }\end{array}$} \\
\hline & & \multirow{2}{*}{$\begin{array}{l}\text { Published } \\
\text { (Ma) }\end{array}$} & \multirow{2}{*}{$\begin{array}{l}\text { Error } \\
(\mathrm{m} . \mathrm{y} .)\end{array}$} & & & & & & \\
\hline & & & & Top & Bottom & Top & Bottom & Median & \\
\hline & & & & 318-U1361A- & 318-U1361A- & & & & \\
\hline D & LO Actinocyclus ingens & 0.535 & 0.035 & $1 \mathrm{H}-\mathrm{CC}$ & $2 \mathrm{H}-\mathrm{CC}$ & 9.03 & 19.04 & 14.04 & 5.01 \\
\hline $\mathrm{R}$ & LO Antarctissa cylindrica & 0.600 & & $1 \mathrm{H}-\mathrm{CC}$ & $4 \mathrm{H}-\mathrm{CC}$ & 9.03 & 36.53 & 22.78 & 13.75 \\
\hline D & LO Thalassiosira elliptipora & 0.675 & 0.035 & $2 \mathrm{H}-\mathrm{CC}$ & $3 \mathrm{H}-\mathrm{CC}$ & 19.04 & 28.26 & 23.65 & 4.61 \\
\hline D & LO Thalassiosira fasciculata & 0.890 & 0 & $1 \mathrm{H}-\mathrm{CC}$ & $3 \mathrm{H}-\mathrm{CC}$ & 9.03 & 28.26 & 18.65 & 9.62 \\
\hline D & LO Fragilariopsis barronii & 1.240 & 0.05 & $2 \mathrm{H}-\mathrm{CC}$ & $3 \mathrm{H}-\mathrm{CC}$ & 19.04 & 28.26 & 23.65 & 4.61 \\
\hline D & FO Fragilariopsis separanda & 1.410 & 0.04 & $2 \mathrm{H}-\mathrm{CC}$ & $3 \mathrm{H}-\mathrm{CC}$ & 19.04 & 28.26 & 23.65 & 4.61 \\
\hline D & LO Rouxia antarctica & 1.495 & 0.015 & $2 \mathrm{H}-\mathrm{CC}$ & $3 \mathrm{H}-\mathrm{CC}$ & 19.04 & 28.26 & 23.65 & 4.61 \\
\hline D & FO Fragilariopsis obliquecostata & 1.695 & 0.035 & $4 \mathrm{H}-\mathrm{CC}$ & $5 \mathrm{H}-\mathrm{CC}$ & 36.53 & 47.42 & 41.98 & 5.45 \\
\hline \multirow[t]{2}{*}{ PM } & Chron C2n (y) & 1.778 & & $4 \mathrm{H}-3,130$ & $4 \mathrm{H}-3,135$ & 32.30 & 32.35 & 32.33 & 0.03 \\
\hline & Pliocene/Pleistocene boundary & 1.81 & & $4 \mathrm{H}-3,135$ & $4 \mathrm{H}-5,85$ & 32.35 & 34.80 & 33.58 & 1.23 \\
\hline PM & Chron C2n (o) & 1.945 & & $4 \mathrm{H}-5,85$ & $4 \mathrm{H}-5,85$ & 34.80 & 34.80 & 34.80 & 0.00 \\
\hline D & FO Thalassiosira elliptipora & 2.030 & 0.03 & $4 \mathrm{H}-\mathrm{CC}$ & $5 \mathrm{H}-\mathrm{CC}$ & 36.53 & 47.42 & 41.98 & 5.45 \\
\hline D & FO Fragilariopsis kerguelensis & 2.195 & 0.015 & $3 \mathrm{H}-\mathrm{CC}$ & $4 \mathrm{H}-\mathrm{CC}$ & 28.26 & 36.53 & 32.40 & 4.14 \\
\hline $\mathrm{R}$ & LO Helotholus vema & 2.300 & & $4 \mathrm{H}-\mathrm{CC}$ & $6 \mathrm{H}-\mathrm{CC}$ & 36.53 & 56.72 & 46.63 & 10.10 \\
\hline D & LO Thalassiosira insigna & 2.475 & 0.025 & $5 \mathrm{H}-\mathrm{CC}$ & $6 \mathrm{H}-\mathrm{CC}$ & 47.42 & 56.72 & 52.07 & 4.65 \\
\hline D & LO Fragilariopsis weaveri & 2.490 & 0.04 & $6 \mathrm{H}-\mathrm{CC}$ & $7 \mathrm{H}-\mathrm{CC}$ & 56.72 & 66.55 & 61.64 & 4.92 \\
\hline D & LO Thalassiosira inura & 2.540 & 0.01 & $5 \mathrm{H}-\mathrm{CC}$ & $6 \mathrm{H}-\mathrm{CC}$ & 47.42 & 56.72 & 52.07 & 4.65 \\
\hline PM & Chron C2An.1n (y) & 2.581 & & $6 \mathrm{H}-2,120$ & $6 \mathrm{H}-2,125$ & 49.70 & 49.75 & 49.73 & 0.02 \\
\hline PM & Chron C2An.1r (y) & 3.032 & & $7 \mathrm{H}-6,55$ & $7 \mathrm{H}-6,60$ & 64.55 & 64.60 & 64.58 & 0.02 \\
\hline PM & Chron C2An.2n (y) & 3.116 & & $8 \mathrm{H}-1,70$ & $8 \mathrm{H}-1,70$ & 66.70 & 66.70 & 66.70 & 0.00 \\
\hline D & FO Thalassiosira vulnifica & 3.150 & 0.03 & $6 \mathrm{H}-\mathrm{CC}$ & 7H-CC & 56.72 & 66.55 & 61.64 & 4.92 \\
\hline PM & Chron C2An.2r (y) & 3.207 & & $8 \mathrm{H}-4,115$ & $8 \mathrm{H}-4,120$ & 71.67 & 71.72 & 71.70 & 0.02 \\
\hline D & FO Thalassiosira insigna & 3.250 & 0.11 & $6 \mathrm{H}-\mathrm{CC}$ & $7 \mathrm{H}-\mathrm{CC}$ & 56.72 & 66.55 & 61.64 & 4.92 \\
\hline PM & Chron C2An.3n (y) & 3.330 & & $8 \mathrm{H}-6,100$ & $9 \mathrm{H}-1,40$ & 74.52 & 75.90 & 75.21 & 0.69 \\
\hline D & FO Fragilariopsis weaveri & 3.530 & 0.02 & $7 \mathrm{H}-\mathrm{CC}$ & $8 \mathrm{H}-\mathrm{CC}$ & 66.55 & 75.17 & 70.86 & 4.31 \\
\hline PM & Chron C2Ar (y) & 3.596 & & $9 \mathrm{H}-2,45$ & $9 \mathrm{H}-2,50$ & 77.45 & 77.50 & 77.48 & 0.02 \\
\hline PM & Chron C3n.1n (y) & 4.187 & & $11 \mathrm{H}-4,120$ & $11 \mathrm{H}-4,125$ & 100.20 & 100.25 & 100.23 & 0.02 \\
\hline $\mathrm{R}$ & FO Helotholus vema & 4.200 & & $11 \mathrm{H}-\mathrm{CC}$ & $12 \mathrm{H}-\mathrm{CC}$ & 104.26 & 111.32 & 107.79 & 3.53 \\
\hline $\mathrm{R}$ & LO Eucyrtidium pseudoinflatum & 4.200 & & $10 \mathrm{H}-\mathrm{CC}$ & $11 \mathrm{H}-\mathrm{CC}$ & 94.99 & 104.26 & 99.63 & 4.64 \\
\hline D & FO Fragilariopsis barronii & 4.400 & 0.12 & $11 \mathrm{H}-\mathrm{CC}$ & $12 \mathrm{H}-\mathrm{CC}$ & 104.26 & 111.32 & 107.79 & 3.53 \\
\hline PM & Chron C $3 n .2 n(0)$ & 4.631 & & $12 \mathrm{H}-6,40$ & $12 \mathrm{H}-6,40$ & 109.69 & 109.69 & 109.69 & 0.00 \\
\hline D & FO Thalassiosira inura & 4.740 & 0.03 & $14 \mathrm{H}-\mathrm{CC}$ & $15 X-C C$ & 132.57 & 141.76 & 137.17 & 4.60 \\
\hline D & FO Shionodiscus oestrupii & 4.875 & 0.075 & $12 \mathrm{H}-\mathrm{CC}$ & $13 \mathrm{H}-\mathrm{CC}$ & 111.32 & 122.57 & 116.95 & 5.63 \\
\hline PM & Chron C3n.4n (y) & 4.997 & & $13 \mathrm{H}-5,80$ & $13 \mathrm{H}-5,85$ & 120.30 & 120.35 & 120.33 & 0.02 \\
\hline $\mathrm{R}$ & LCO Lychnocanium grande & 5.000 & & $12 \mathrm{H}-\mathrm{CC}$ & $18 \mathrm{X}-\mathrm{CC}$ & 111.32 & 167.10 & 139.21 & 27.89 \\
\hline \multirow[t]{2}{*}{ PM } & Chron C3n.4n (o) & 5.235 & & $14 \mathrm{H}-1,65$ & $14 \mathrm{H}-1,70$ & 123.65 & 123.70 & 123.68 & 0.03 \\
\hline & Miocene/Pliocene boundary & 5.33 & & $14 \mathrm{H}-1,70$ & $16 \mathrm{H}-2,30$ & 123.70 & 143.80 & 133.75 & 10.05 \\
\hline D & LO Thalassiosira miocenica & 5.910 & 1.01 & $17 \mathrm{H}-\mathrm{CC}$ & $18 \mathrm{X}-\mathrm{CC}$ & 160.34 & 167.10 & 163.72 & 3.38 \\
\hline D & LO Fragilariopsis donahuensis & 5.980 & 0.88 & $17 \mathrm{H}-\mathrm{CC}$ & $18 \mathrm{X}-\mathrm{CC}$ & 160.34 & 167.10 & 163.72 & 3.38 \\
\hline PM & Chron C3An.1n (y) & 6.033 & & $16 \mathrm{H}-2,30$ & $16 \mathrm{H}-2,35$ & 143.80 & 143.85 & 143.83 & 0.02 \\
\hline D & FO Thalassiosira oliverana & 6.175 & 1.035 & $22 \mathrm{X}-\mathrm{CC}$ & $23 \mathrm{X}-\mathrm{CC}$ & 205.21 & 215.90 & 210.56 & 5.35 \\
\hline PM & Chron C3An.2n (o) & 6.733 & & $17 X-2,80$ & $17 X-2,85$ & 153.80 & 153.85 & 153.83 & 0.02 \\
\hline D & LO Thalassiosira mahoodii & 6.850 & & $18 \mathrm{X}-\mathrm{CC}$ & $20 \mathrm{X}-\mathrm{CC}$ & 167.10 & 184.41 & 175.76 & 8.66 \\
\hline D & FO Thalassiosira torokina & 7.230 & 0.8 & $23 \mathrm{X}-\mathrm{CC}$ & $24 \mathrm{X}-\mathrm{CC}$ & 215.90 & 219.12 & 217.51 & 1.61 \\
\hline D & FO Thalassiosira miocenica & 7.290 & 1.04 & $18 \mathrm{X}-\mathrm{CC}$ & $20 \mathrm{X}-\mathrm{CC}$ & 167.10 & 184.41 & 175.76 & 8.66 \\
\hline $\mathrm{R}$ & FO Acrosphaera? labrata & 7.800 & & $20 \mathrm{X}-\mathrm{CC}$ & $22 \mathrm{X}-\mathrm{CC}$ & 184.41 & 205.21 & 194.81 & 10.40 \\
\hline D & FO Thalassiosira mahoodii & 8.470 & & $27 X-C C$ & $28 \mathrm{X}-\mathrm{CC}$ & 253.00 & 263.91 & 258.46 & 5.46 \\
\hline D & LAO Denticulopsis simonsenii & 8.625 & 0.055 & $22 \mathrm{X}-\mathrm{CC}$ & $23 \mathrm{X}-\mathrm{CC}$ & 205.21 & 215.90 & 210.56 & 5.35 \\
\hline $\mathrm{R}$ & LO Cycladophora spongothrax & 9.100 & & $23 \mathrm{X}-\mathrm{CC}$ & $26 \mathrm{X}-\mathrm{CC}$ & 215.90 & 244.24 & 225.36 & 9.46 \\
\hline D & LO Denticulopsis ovata & 9.640 & 1.07 & $31 \mathrm{X}-\mathrm{CC}$ & $32 \mathrm{X}-\mathrm{CC}$ & 283.09 & 302.10 & 292.60 & 9.51 \\
\hline D & LO Denticulopsis dimorpha var. areolata & 10.245 & 0.525 & $33 \mathrm{X}-\mathrm{CC}$ & $34 \mathrm{X}-\mathrm{CC}$ & 311.68 & 321.07 & 316.38 & 4.69 \\
\hline $\mathrm{R}$ & FO Acrosphaera australis & 10.400 & & $30 \mathrm{X}-\mathrm{CC}$ & $31 X-C C$ & 273.55 & 283.09 & 278.32 & 4.77 \\
\hline $\mathrm{R}$ & FO Eucyritidium pseudoinflatum & 10.500 & & $31 \mathrm{X}-\mathrm{CC}$ & & 283.09 & & & \\
\hline D & LCO Denticulopsis dimorpha s.I. & 10.775 & 0.195 & $33 \mathrm{X}-\mathrm{CC}$ & $34 \mathrm{X}-\mathrm{CC}$ & 311.68 & 321.07 & 316.38 & 4.69 \\
\hline $\mathrm{R}$ & LO Actinomma golowini & 10.800 & & & $34 \mathrm{X}-\mathrm{CC}$ & & 321.07 & & \\
\hline PM & Chron C5n.2n (o) & 11.040 & & $34 X-2,138$ & $34 X-3,20$ & 314.48 & 314.80 & 314.64 & 0.16 \\
\hline PM & Chron C5An.1n (y) & 12.014 & & $41 X-1,44$ & $41 X-5,3$ & 378.84 & 384.43 & 381.64 & 2.80 \\
\hline $\mathrm{D}$ & FO Denticulopsis dimorpha s.I. & 12.500 & 0.04 & $39 \mathrm{R}-\mathrm{CC}$ & $40 X-C C$ & 369.26 & 378.24 & 373.75 & 4.49 \\
\hline
\end{tabular}

Notes: $\mathrm{D}=$ diatoms, $\mathrm{R}=$ radiolarians, $\mathrm{PM}=$ paleomagnetic event. $\mathrm{FO}=$ first occurrence, $\mathrm{LAO}=$ last abundant occurrence, $\mathrm{LCO}=$ last common occurrence, $L O=$ last occurrence. $y=$ young, $\mathrm{o}=$ old. 
Table T7. Magnetostratigraphic tie points, Site U1361. (See table notes.)

\begin{tabular}{|c|c|c|c|c|c|}
\hline \multirow{2}{*}{$\begin{array}{l}\text { Chron } \\
\text { boundary }\end{array}$} & \multicolumn{2}{|c|}{ Core, section, interval $(\mathrm{cm})$} & \multicolumn{2}{|c|}{ Depth (mbsf) } & \multirow{2}{*}{$\begin{array}{l}\text { Age } \\
(\mathrm{Ma})\end{array}$} \\
\hline & Top & Bottom & Top & Bottom & \\
\hline & 318-U1361A- & 318-U1361A- & & & \\
\hline C2n (y) & $4 \mathrm{H}-3,130$ & $4 \mathrm{H}-3,135$ & 32.30 & 32.35 & 1.778 \\
\hline C2r (o) & $4 \mathrm{H}-5,85$ & $4 \mathrm{H}-5,85$ & 34.80 & 34.80 & 1.945 \\
\hline C2An.1n (y) & $6 \mathrm{H}-2,120$ & $6 \mathrm{H}-2,125$ & 49.70 & 49.75 & 2.581 \\
\hline C2An.1r (y) & $7 \mathrm{H}-6,55$ & $7 \mathrm{H}-6,60$ & 64.55 & 64.60 & 3.032 \\
\hline C2An.2n (y) & $8 \mathrm{H}-1,70$ & $8 \mathrm{H}-1,70$ & 66.70 & 66.70 & 3.116 \\
\hline C2An.2r (y) & $8 \mathrm{H}-4,115$ & $8 \mathrm{H}-4,120$ & 71.67 & 71.72 & 3.207 \\
\hline C2An.3n (y) & $8 \mathrm{H}-6,100$ & $9 \mathrm{H}-1,40$ & 74.52 & 75.90 & 3.330 \\
\hline C2Ar $(y)$ & $9 \mathrm{H}-2,45$ & $9 \mathrm{H}-2,50$ & 77.45 & 77.50 & 3.596 \\
\hline C3n.1n (y) & $11 \mathrm{H}-4,120$ & $11 \mathrm{H}-4,125$ & 100.20 & 100.25 & 4.187 \\
\hline C $3 n .2 n(0)$ & $12 \mathrm{H}-6,40$ & $12 \mathrm{H}-6,40$ & 109.69 & 109.69 & 4.631 \\
\hline C3n.4n (y) & $13 \mathrm{H}-5,80$ & $13 \mathrm{H}-5,85$ & 120.30 & 120.35 & 4.997 \\
\hline C3n.4n (o) & $14 \mathrm{H}-1,65$ & $14 \mathrm{H}-1,70$ & 123.65 & 123.70 & 5.235 \\
\hline C3An.1n (y) & $16 \mathrm{H}-2,30$ & $16 \mathrm{H}-2,35$ & 143.80 & 143.85 & 6.033 \\
\hline C3An.2n (o) & $17 X-2,80$ & $17 X-2,85$ & 153.80 & 153.85 & 6.733 \\
\hline C5n.2n (o) & $34 X-2,138$ & $34 X-3,20$ & 314.48 & 314.80 & 11.040 \\
\hline C5An.1n (y) & $41 X-1,44$ & $41 X-5,3$ & 378.84 & 384.43 & 12.014 \\
\hline
\end{tabular}

Notes: $y=$ young, $o=$ old. Correlations shown in Figure F12. Ages from Gradstein et al. (2004) timescale.

Table T8. Composite depth scale, Site U1361.

\begin{tabular}{ccrr}
\hline & \multirow{2}{*}{$\begin{array}{c}\text { Offset } \\
\text { Core }\end{array}$} & \multicolumn{2}{c}{ Top depth } \\
\cline { 3 - 4 } & \multicolumn{1}{c}{ (mbsf) } & (mcd) \\
\hline 318-U1361A- & & \\
1H & 0.52 & 0.00 & 0.52 \\
$2 \mathrm{H}$ & 0.52 & 9.00 & 9.52 \\
$3 \mathrm{H}$ & 0.52 & 18.50 & 19.02 \\
$4 \mathrm{H}$ & 0.52 & 28.00 & 28.52 \\
$5 \mathrm{H}$ & 0.52 & 37.50 & 38.02 \\
$6 \mathrm{H}$ & 0.52 & 47.00 & 47.52 \\
$7 \mathrm{H}$ & 0.52 & 56.50 & 57.02 \\
$8 \mathrm{H}$ & 0.52 & 66.00 & 66.52 \\
$9 \mathrm{H}$ & 0.52 & 75.50 & 76.02 \\
$10 \mathrm{H}$ & 0.52 & 85.00 & 85.52 \\
$11 \mathrm{H}$ & 0.52 & 94.50 & 95.02 \\
$12 \mathrm{H}$ & 0.52 & 104.00 & 104.52 \\
$13 \mathrm{H}$ & 0.52 & 113.50 & 114.02 \\
$14 \mathrm{H}$ & 0.52 & 123.00 & 123.52 \\
$15 \mathrm{H}$ & 0.52 & 132.50 & 133.02 \\
$16 \mathrm{H}$ & 0.52 & 142.00 & 142.52 \\
$17 \mathrm{X}$ & 0.52 & 151.50 & 152.02 \\
$18 \mathrm{X}$ & 0.52 & 158.20 & 158.72 \\
$19 \mathrm{X}$ & 0.52 & 167.80 & 168.32 \\
$20 \mathrm{X}$ & 0.52 & 177.40 & 177.92 \\
$21 \mathrm{X}$ & 0.52 & 187.00 & 187.52 \\
$22 \mathrm{X}$ & 0.52 & 196.60 & 197.12
\end{tabular}

\begin{tabular}{cccc}
\hline & \multirow{2}{*}{$\begin{array}{c}\text { Offset } \\
\text { Core }\end{array}$} & $(\mathrm{m})$ & Top depth \\
\cline { 3 - 4 } $23 \mathrm{mbsf})$ & (mcd) \\
\hline $24 \mathrm{X}$ & 0.52 & 206.20 & 206.72 \\
$25 \mathrm{X}$ & 0.52 & 215.80 & 216.32 \\
$26 \mathrm{X}$ & 0.52 & 225.40 & 225.92 \\
$27 \mathrm{X}$ & 0.52 & 235.00 & 235.52 \\
$28 \mathrm{X}$ & 0.52 & 244.60 & 245.12 \\
$29 \mathrm{X}$ & 0.52 & 254.20 & 254.72 \\
$30 \mathrm{X}$ & 0.52 & 273.40 & 264.32 \\
$31 \mathrm{X}$ & 0.52 & 283.00 & 283.92 \\
$32 \mathrm{X}$ & 0.52 & 292.50 & 293.02 \\
$33 \mathrm{X}$ & 0.52 & 302.00 & 302.52 \\
$34 \mathrm{X}$ & 0.52 & 311.60 & 312.12 \\
$35 \mathrm{X}$ & 0.52 & 321.20 & 321.72 \\
$36 \mathrm{X}$ & 0.52 & 330.80 & 331.32 \\
$37 \mathrm{X}$ & 0.52 & 340.40 & 340.92 \\
$38 \mathrm{X}$ & 0.52 & 350.00 & 350.52 \\
$39 \mathrm{X}$ & 0.52 & 359.60 & 360.12 \\
$40 \mathrm{X}$ & 0.52 & 368.90 & 369.42 \\
$41 \mathrm{X}$ & 0.52 & 378.40 & 378.92 \\
$318-\mathrm{U} 1361 \mathrm{~B}-$ & & \\
$1 \mathrm{H}$ & 0.00 & 0.00 & 0.00 \\
$2 \mathrm{H}$ & 0.00 & 2.60 & 2.60 \\
\hline & & &
\end{tabular}


Table T9. Splice tie points, Site U1361.

\begin{tabular}{|c|c|c|c|c|c|c|}
\hline \multirow{2}{*}{$\begin{array}{l}\text { Hole, core, section, } \\
\text { interval }(\mathrm{cm})\end{array}$} & \multicolumn{2}{|c|}{ Depth } & & \multirow{2}{*}{$\begin{array}{l}\text { Hole, core, section, } \\
\text { interval }(\mathrm{cm})\end{array}$} & \multicolumn{2}{|c|}{ Depth } \\
\hline & (mbsf) & $(\mathrm{mcd})$ & & & (mbsf) & $(\mathrm{mcd})$ \\
\hline 318- & & & & 318- & & \\
\hline U1361A- & 3.50 & 4.02 & Tie to & U136 & 4.02 & 4.02 \\
\hline U1361B-2H-7, 39 & 11.71 & 11.71 & Tie to & U1361A-2H-2, 69 & 11.19 & 11.71 \\
\hline U1361A-2H-7, 85 & 18.85 & 19.37 & Append & U1361A-3H-1, 0 & 18.50 & 19.02 \\
\hline
\end{tabular}

Table T10. Temperature profiles, Hole U1361A. (See table notes.)

\begin{tabular}{ccccl}
\hline Core & $\begin{array}{c}\text { Depth } \\
(\mathrm{mbsf})\end{array}$ & $\begin{array}{c}\text { Temperature } \\
\left({ }^{\circ} \mathrm{C}\right)\end{array}$ & $\begin{array}{c}\text { Thermal resistance } \\
\left(\mathrm{m}^{2} \mathrm{~K} / \mathrm{W}\right)\end{array}$ & \multicolumn{1}{c}{ Remark } \\
\hline $318-\mathrm{U} 1361 \mathrm{~A}-$ & & & \\
& 0.0 & -0.3 & 0 & Mudline temperature \\
$4 \mathrm{H}$ & 37.5 & $\mathrm{NA}$ & $\mathrm{NA}$ & Unusable \\
$7 \mathrm{H}$ & 66.0 & 4.37 & 73.54 & Moderate sea \\
$10 \mathrm{H}$ & 94.5 & 5.58 & 103.77 & $\begin{array}{l}\text { Moderate sea } \\
13 \mathrm{H}\end{array}$ \\
123.0 & $\mathrm{NA}$ & $\mathrm{NA}$ & Unusable \\
\hline
\end{tabular}

Notes: NA = not available. In situ temperatures were determined using the TP-Fit software. Thermal resistance was calculated from thermal conductivity data (see "Physical properties") corrected for in situ conditions (see "Downhole logging" in the "Methods" chapter). 